\title{
Review of Hazards Associated with Molten Salt Reactor Fuel Processing Operations
}

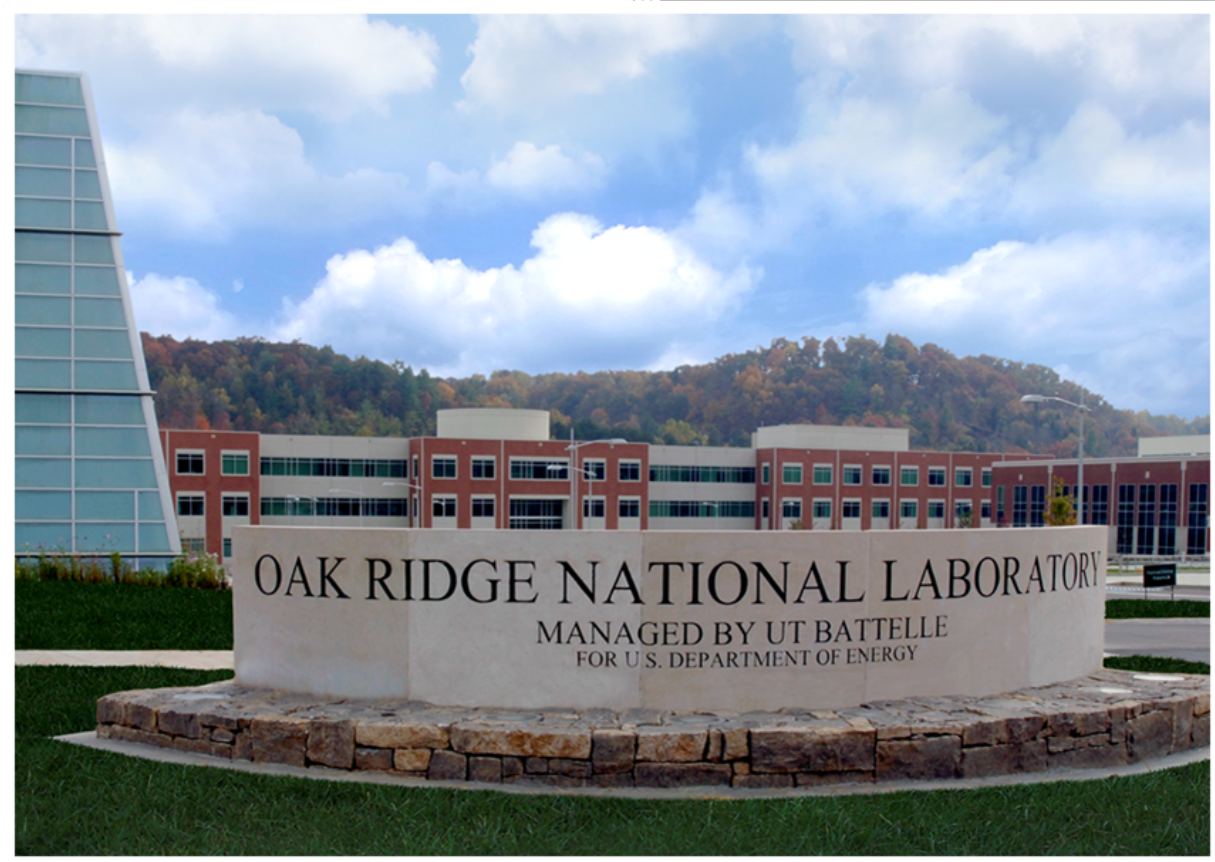

Approved for public release. Distribution is unlimited.

Joanna McFarlane

Paul Taylor

David Holcomb

W. P. Poore

June 2019 


\section{DOCUMENT AVAILABILITY}

Reports produced after January 1, 1996, are generally available free via US Department of Energy (DOE) SciTech Connect.

Website www.osti.gov

Reports produced before January 1, 1996, may be purchased by members of the public from the following source:

National Technical Information Service

5285 Port Royal Road

Springfield, VA 22161

Telephone 703-605-6000 (1-800-553-6847)

TDD 703-487-4639

Fax 703-605-6900

E-mail info@ntis.gov

Website http://classic.ntis.gov/

Reports are available to DOE employees, DOE contractors, Energy Technology Data Exchange representatives, and International Nuclear Information System representatives from the following source:

Office of Scientific and Technical Information

PO Box 62

Oak Ridge, TN 37831

Telephone 865-576-8401

Fax 865-576-5728

E-mail reports@osti.gov

Website http://www.osti.gov/contact.html

This report was prepared as an account of work sponsored by an agency of the United States Government. Neither the United States Government nor any agency thereof, nor any of their employees, makes any warranty, express or implied, or assumes any legal liability or responsibility for the accuracy, completeness, or usefulness of any information, apparatus, product, or process disclosed, or represents that its use would not infringe privately owned rights. Reference herein to any specific commercial product, process, or service by trade name, trademark, manufacturer, or otherwise, does not necessarily constitute or imply its endorsement, recommendation, or favoring by the United States Government or any agency thereof. The views and opinions of authors expressed herein do not necessarily state or reflect those of the United States Government or any agency thereof. 
Isotope and Fuel Cycle Technology Division

Reactor and Nuclear Systems Division

\title{
REVIEW OF HAZARDS ASSOCIATED WITH MOLTEN SALT REACTOR FUEL PROCESSING OPERATIONS
}

\author{
Joanna McFarlane \\ Paul Taylor \\ David Holcomb \\ W. P. Poore
}

June 2019

Prepared by

OAK RIDGE NATIONAL LABORATORY

Oak Ridge, TN 37831-6283

managed by

UT-BATTELLE, LLC

for the

US DEPARTMENT OF ENERGY

under contract DE-AC05-00OR22725 



\section{CONTENTS}

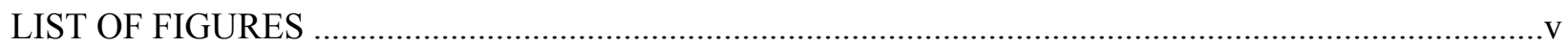

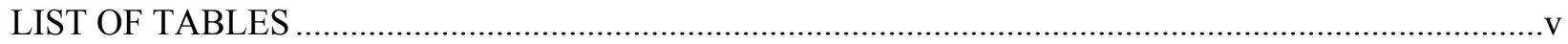

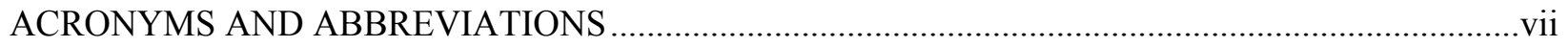

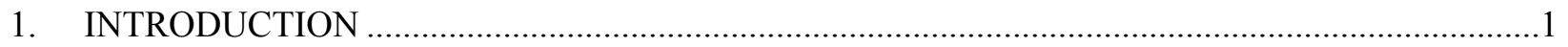

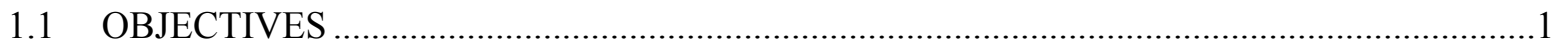

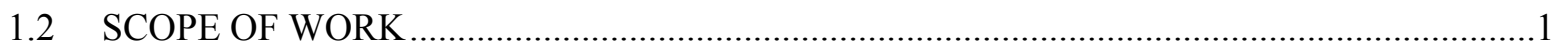

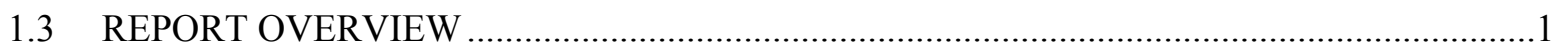

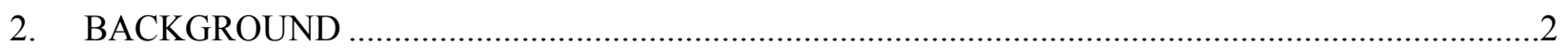

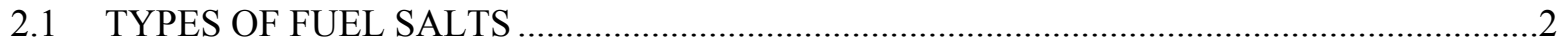

2.2 HISTORIC FUEL SALT PREPARATION FACILITIES .................................................

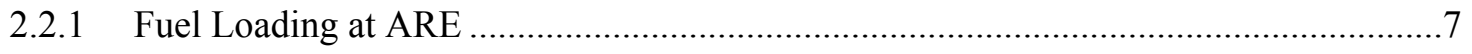

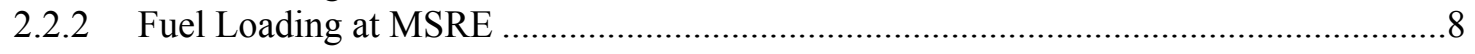

2.2.3 Stripping Uranium from MSRE Fuel and Flush Salts .............................................10

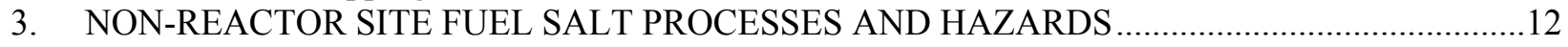

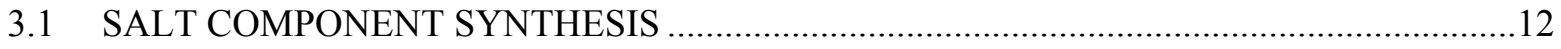

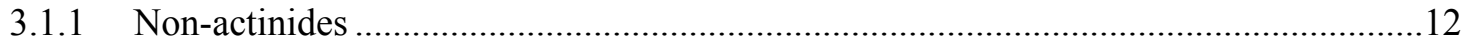

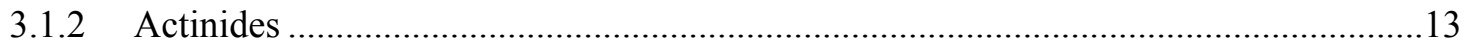

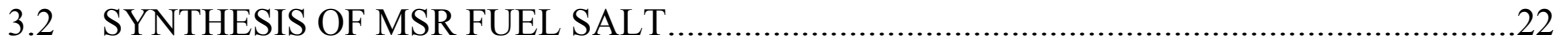

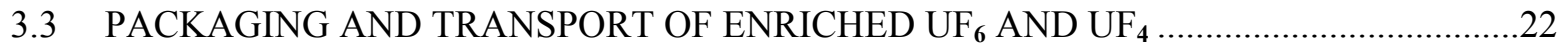

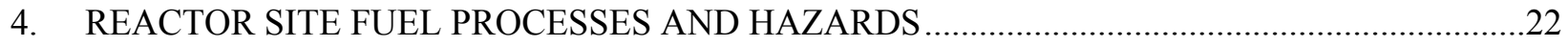

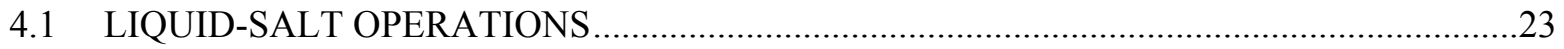

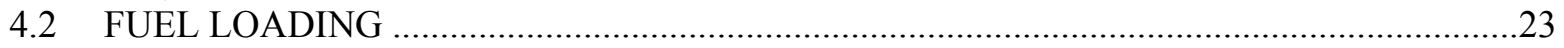

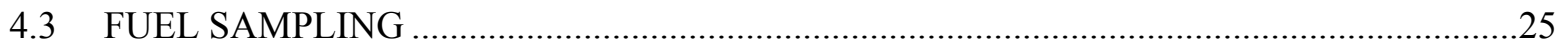

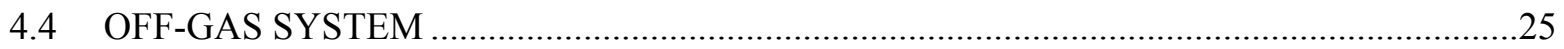

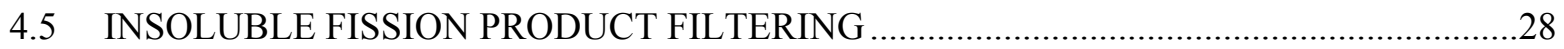

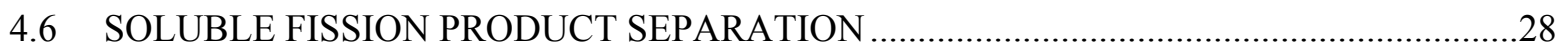

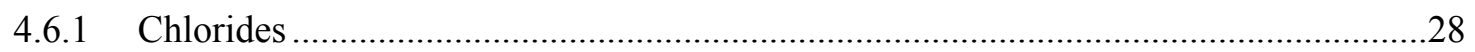

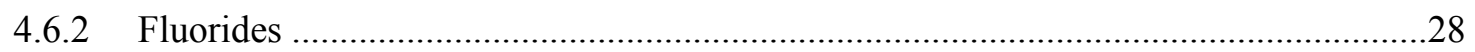

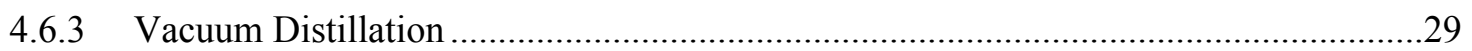

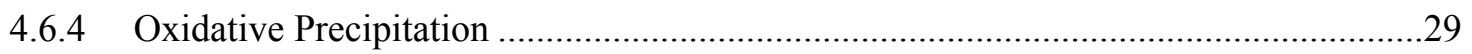

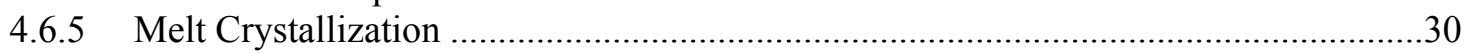

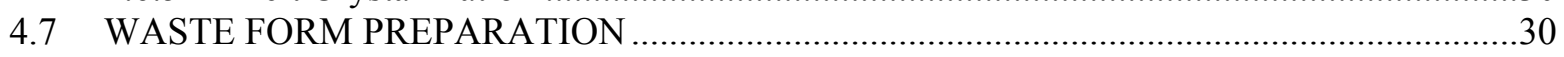

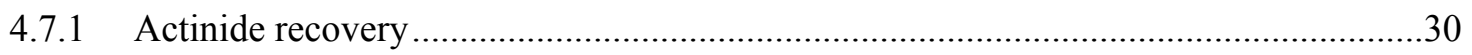

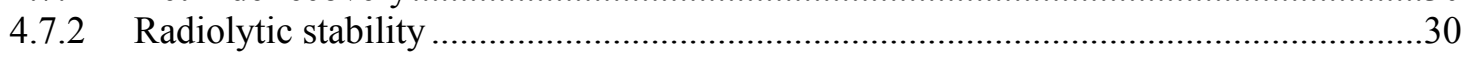

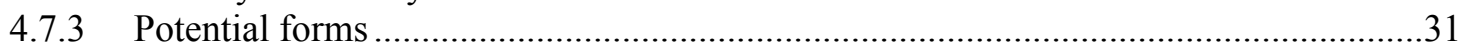

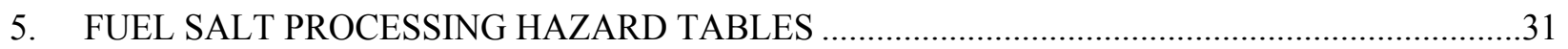

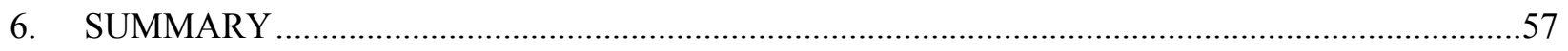





\section{LIST OF FIGURES}

Figure 1. Flow diagram of ARE fluoride salt production facilities (Figure 1 from ORNL-CF-54-6-

126).

Figure 2. MSRE era fluoride salt production facility layout..

Figure 3. Fluoride production facility, batch-processing unit (ORNL Photo 39428)

Figure 4. Beryllium salt production; operator wearing a fresh-air suit (ORNL Photo 70837) .....................

Figure 5. ARE fuel concentrate addition system layout (Figure 4.2 from ORNL-1845) ........................8

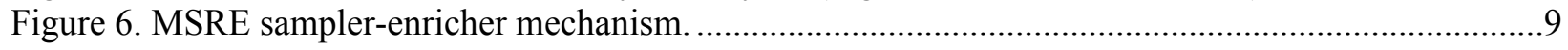

Figure 7. MSRE sampling and enriching capsules (ORNL Photo 71333). ............................................10

Figure 8. MSRE Uranium Stripping fuel processing system flowsheet. ................................................11

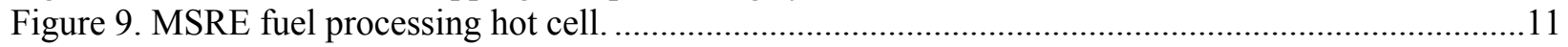

Figure 10. Schematic of the proposed chop-voloxidize-hydrofluorinate process flow sheet.....................19

Figure 11. Schematic of the proposed chemical decladding-voloxidize-hydrofluorinate process

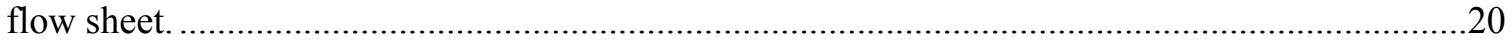

Figure 12. Concept for converting used fuel to fluoride salts by molten salt dissolution. ........................21

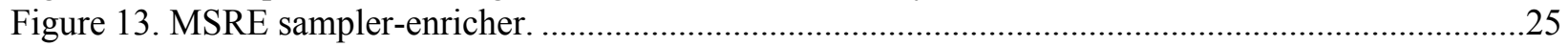

\section{LIST OF TABLES}

Table 1. Fuel salt optimization characteristics and rationale ..................................................................

Table 2. Table of analyses of $\mathrm{LiF}_{-} \mathrm{BeF}_{2}$ for MSRE coolant and flush salts (Thoma ORNL-4658)............13

Table 3a. Off-site nuclear fuel preparation and handling ......................................................................33

Table 3b. Operations conducted on site prior to reactor operation (initial criticality) ...............................35

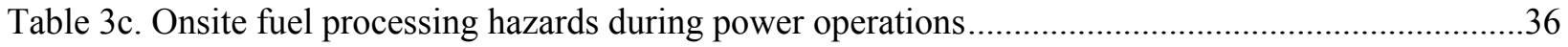

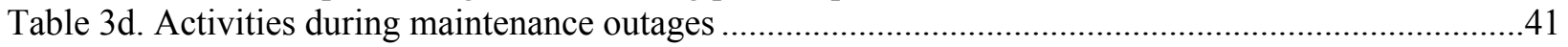

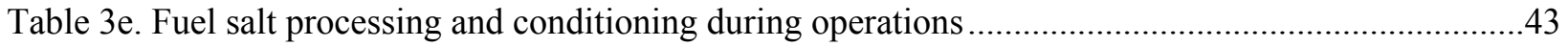

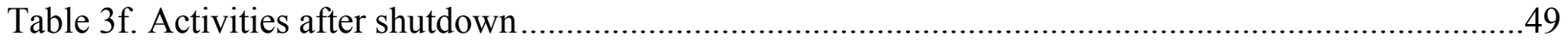

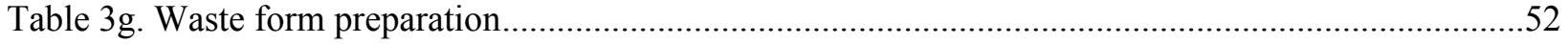





\section{ACRONYMS AND ABBREVIATIONS}

$\begin{array}{ll}\text { ADAMS } & \text { Agencywide Documents Access and Management System } \\ \text { ANSI } & \text { American National Standards Institute } \\ \text { ARE } & \text { Aircraft Reactor Experiment } \\ \text { CEA } & \text { Commissariat à l'Energie Atomique } \\ \text { CFR } & \text { US Code of Federal Regulations } \\ \text { CO } & \text { carbon monoxide } \\ \text { DOT } & \text { US Department of Transportation } \\ \text { FP } & \text { fission product } \\ \text { GMODS } & \text { glass material oxidation and dissolution system } \\ \text { HF } & \text { hydrogen fluoride } \\ \text { KI } & \text { potassium iodide } \\ \text { KOH } & \text { potassium hydroxide } \\ \text { LWR } & \text { light-water reactor } \\ \text { M } & \text { metals } \\ \text { MSBR } & \text { molten salt breeder reactor } \\ \text { MSR } & \text { molten salt reactor } \\ \text { MSRE } & \text { Molten Salt Reactor Experiment } \\ \text { NO } & \text { nitric oxide } \\ \text { NRC } & \text { US Nuclear Regulatory Commission } \\ \text { ORNL } & \text { Oak Ridge National Laboratory } \\ \text { OSHA } & \text { Occupational Safety and Health Administration } \\ \text { PEL } & \text { permissible exposure limit } \\ \text { PNNL } & \text { Pacific Northwest National Laboratory } \\ \text { TRL } & \text { technology readiness level } \\ \text { TRU } & \text { transuranic } \\ \text { TWA } & \text { time-weighted average }\end{array}$





\section{INTRODUCTION}

This document provides a review of the hazards associated with molten salt reactor fuel processing operations. Project objectives, scope, and an overview of the report are presented in the sections below.

\subsection{OBJECTIVES}

This project supports the US Nuclear Regulatory Commission (NRC) non-LWR Vision and Strategy Near-Term Implementation Action Plans (Agency-wide Documents Access and Management System [ADAMS] Accession No. ML17165A069). The main objective is to assure technical and regulatory readiness by identifying and resolving gaps in the regulatory framework for non-light water reactor (nonLWR) technologies and their associated fuel cycles. One of these gaps is the availability of aids for the review of hazards associated with fluid-fueled molten salt reactor (MSR) fuel processing operations, which is the subject of this work. Such operations involve hazards that are substantially different from those associated with uranium oxide fuel fabrication and handling.

\subsection{SCOPE OF WORK}

This report presents the results of an effort to identify hazards associated with MSR fuel processing operations and activities. The report describes processes for storing, synthesizing, using, treating, and disposing of MSR fuel salts and the hazards associated with each process. Many of these processes will be performed at a reactor facility as part of normal operations. However, some activities, such as bulk salt preparation for the initial reactor load and refueling aliquot preparation, appear more likely to be performed at a dedicated fuel salt processing facility. Processing hazards associated with MSR fuel salt preparation are largely independent of whether they are performed at offsite facilities or at the reactor site. Therefore, this document identifies both on- and off-site hazards.

Reactor operations associated with fuel salt processing are also addressed in this report. However, hazards associated with general reactor operations are beyond the scope of this effort. Additionally, common industrial hazards such as poor ergonomics, trips/falls, noise, electricity, movement of heavy or bulky materials, etc., are outside the report scope. The report also includes qualitative assessments of the maturity of likely fuel processing operations and activities, which may require both technology maturation and scale-up for industrial use. The report also addresses the consequences of potential hazards. These expert judgments convey the confidence of the present knowledge of the processes and identify the most hazardous aspects of the processes or operations.

MSR designs are not fully mature; nor are the designs for the primary and ancillary support systems for the synthesis and treatment of molten salt fuel. The types of processes and their hazards addressed in this report are extrapolated from experience at MSRs and from fuel salt laboratory-, test-, or operating-scale (for non-fuel salts) facilities. Therefore, this report is not a process hazards analysis (PHA), which would typically be performed on a specific design for a particular application. However, this document could inform the design process and subsequent PHA or other safety studies for deployed systems.

\subsection{REPORT OVERVIEW}

Section 2 of this report provides an overview of the types of fuel salts that are anticipated to be used in future MSRs and the rationale for selecting a salt type. An overview of the historic facilities and processes used to prepare fuel salt for experimental and reactor use is also provided.

Section 3 describes the processes and hazards associated with the synthesis of MSR fuel salt. Fuel salt synthesis is likely to take place at a dedicated fuel salt preparation facility. Fuel salt synthesis includes 
preparation of carrier salts and subsequent integration of fissile salt with the carrier salt. Section 4 describes the fuel salt processes and hazards associated with reactor site operations.

Section 5 presents summary tables of the hazards associated with MSR fuel processing operations and activities, along with qualitative assessments of the technical readiness of the processes, the potential consequences of the hazard to operations staff, and potential hazard mitigation methods. Section 6 summarizes the report.

\section{BACKGROUND}

This section provides a background information on the types of fuel salts likely to be employed in MSRs, including a description of the types of fuel salts used in MSRs and the general characteristics of reactors that would use those types of salts. Also, descriptions are provided of the historic facilities and operations used to prepare and process the fuel salt for experimental and reactor use.

The concept of liquid reactor fuel originated with Nobel Laureates Harold Urey and Eugene Wigner during the Manhattan Project as a means to obtain desirable reactor and fuel cycle characteristics. Shortly thereafter, R. C. Briant of Oak Ridge National Laboratory (ORNL) suggested that alkali halide salts could have thermophysical and thermochemical properties to enable high-temperature, low-pressure operation.

\section{$2.1 \quad$ TYPES OF FUEL SALTS}

MSR fuel salts consist of mixtures of fissile and possibly fertile materials, halides, and carrier salts. The primary purpose for carrier salts is to lower the melting point of the mixture, as the melting temperatures of the fissile and fertile halide salts are too high for practical use, and to be able to adjust the concentration of fissionable material to control criticality. MSRs will use one of three classes of fuel salt:

1. Fluorides with low concentrations of fissile and fertile materials

2. Fluorides in which the fissile and fertile materials make up a substantial portion of the salt

3. Chlorides in which fissile and fertile materials make up a substantial portion of the salt

Liquid fuel salt provides the opportunity to alter the salt composition as part of reactor operations. This can occur as a result of adding or removing fuel, fission products (FPs), chemistry adjustment materials, contaminants, or corrosion products. The fact that fuel salt serves as both fuel and coolant in MSRs establishes the performance objectives for fuel salt properties.

The specific composition of the reactor salt is selected by the designers to meet the plant's performance objectives. These objectives could include the amount of power to be produced and the role of the reactor in the fuel cycle as envisioned by its designers and operators.

During the historic Molten Salt Breeder Reactor (MSBR) Program, primary goals were corrosion control and breeding additional fissile resources from a thermal-spectrum ${ }^{232} \mathrm{Th} /{ }^{233} \mathrm{U}$ fuel cycle. A key step in this cycle was separation of ${ }^{233} \mathrm{~Pa}$ to decay in a low-flux region following neutron capture by ${ }^{232} \mathrm{Th}$. Therefore, the selected fuel salt was optimized for coupling with separations processing. Both the Molten Salt Reactor Experiment (MSRE) and the planned MSBR accomplished this by using less than one mole percent uranium in the fuel salt. The MSBR planned to include 12 mole percent fertile $\mathrm{ThF}_{4}$ to enable breeding. Overall, the MSRE fuel salt thermophysical properties were approximately those of the solvent salt. Modern designs that intend to employ the thermal spectrum ${ }^{232} \mathrm{Th} /{ }^{233} \mathrm{U}$ fuel cycle are anticipated to use a similar fuel salt. More details of the logic underlying the fuel salt selection process are provided in Chapter 12, "Chemical Aspects of Molten-Fluoride-Salt Reactor Fuels," in Fluid Fuel Reactors (developed for the Atomic Energy Commission). ${ }^{1}$ 
Table 1. Fuel salt optimization characteristics and rationale

\begin{tabular}{|l|l|}
\hline \multicolumn{1}{|c|}{ Property } & $\begin{array}{l}\text { Low-pressure operation; primary safety feature } \\
\text { High-temperature; more efficiency }\end{array}$ \\
\hline $\begin{array}{l}\text { Reasonably low melting point } \\
\left(<\sim 550^{\circ} \mathrm{C}\right)\end{array}$ & $\begin{array}{l}\text { Readily available, well-known structural alloys; pure actinide halides } \\
\text { have too high melting points for practical use }\end{array}$ \\
\hline $\begin{array}{l}\text { Dissolve or incorporate useful } \\
\text { amounts of fissile and fertile } \\
\text { materials if desired }\end{array}$ & $\begin{array}{l}\text { Sustains criticality; principally a concern for fast-spectrum fluoride } \\
\text { salt reactors due to limited actinide trifluoride solubility }\end{array}$ \\
\hline High radiolytic stability & $\begin{array}{l}\text { Required for in-core operation; desirable for long-term, } \\
\text { post-use storage }\end{array}$ \\
\hline $\begin{array}{l}\text { Chemical compatibility with } \\
\text { moderator and structural materials }\end{array}$ & $\begin{array}{l}\text { Construction and long-term operation using readily available, well- } \\
\text { known materials }\end{array}$ \\
\hline $\begin{array}{l}\text { Chemically unreactive with the } \\
\text { atmosphere and coolant fluids }\end{array}$ & $\begin{array}{l}\text { Safety characteristic to prevent accident cascade following } \\
\text { salt leakage }\end{array}$ \\
\hline Large volumetric heat capacity & $\begin{array}{l}\text { Efficient heat transfer; safety characteristic promoting effective } \\
\text { natural circulation cooling }\end{array}$ \\
\hline Low viscosity & $\begin{array}{l}\text { Efficient heat transfer; safety characteristic promoting effective } \\
\text { natural circulation cooling }\end{array}$ \\
\hline High thermal conductivity & $\begin{array}{l}\text { Efficient heat transfer; safety characteristic promoting effective } \\
\text { natural circulation cooling, as salts generally have low to moderate } \\
\text { thermal conductivity }\end{array}$ \\
\hline Large thermal expansion coefficient & $\begin{array}{l}\text { Safety characteristic promoting effective natural circulation cooling } \\
\text { and assisting with criticality control }\end{array}$ \\
\hline Low parasitic neutron capture & Maintains criticality and efficient fissile resource utilization \\
\hline Low long-lived solvent activation & $\begin{array}{l}\text { Avoids additional radiotoxicity from non-fuel portion of salt; }{ }^{36} \mathrm{Cl} \\
\text { production is a potential concern for chloride salts, S causes } \\
\text { corrosion }\end{array}$ \\
\hline $\begin{array}{l}\text { Safety characteristic to minimize potential source term; noble gas } \\
\text { FPs readily escape fuel salt, and noble metal FPs can plate out onto } \\
\text { structures or precipitate from the fuel salt }\end{array}$ \\
\hline
\end{tabular}

Thermal spectrum reactors that are intended to maximize their conversion ratio and thereby minimize their fissile resource requirements use fluoride fuel salts with the highest possible uranium content while maintaining a low melting point and chemical compatibility with available structural materials. Maximizing the uranium content minimizes the fuel salt volume within the core, minimizing parasitic neutron capture. The moderator is chosen to be graphite that has a lower parasitic neutron capture than fuel salt, so maximizing the ratio of graphite-to-fuel salt in the core improves fuel utilization. Another consideration for fuel salt selection is the availability of separated isotopes. LiF-UF 4 has advantageous properties as a fuel salt, maintaining a melting point below $550^{\circ} \mathrm{C}$ for a $\mathrm{UF}_{4}$ concentration of up to 32 mole percent, but it is only viable if highly separated ${ }^{7} \mathrm{Li}$ is available at a reasonable cost. Note that at higher concentrations of $\mathrm{UF}_{4}$ and other uranium-bearing salts, only a small fraction would be ${ }^{235} \mathrm{U}$.

Fast-spectrum reactors require a substantially higher concentration of fissile materials in their fuel salts to maintain criticality. While either fluoride- or chloride-based salts can be used, only chloride-based salts enable a sufficiently hard spectrum to enable re-fueling with natural uranium without resulting in actinide separation. ${ }^{2}$ These breed-and-burn fast-spectrum MSRs will maximize the amount of uranium in their fuel salt while preserving an acceptably low melt temperature. The phase diagram of $\mathrm{NaCl}^{-\mathrm{UCl}_{3}-\mathrm{a}}$ 
representative chloride fuel salt-shows a melting temperature of less than $550^{\circ} \mathrm{C}$ for $\mathrm{UCl}_{3}$ compositions of up to 35 mole percent. The neutronic efficiency of chloride salt reactors will also be impacted by the availability of isotopically selected chlorine. A high ${ }^{37} \mathrm{Cl}-\mathrm{to}_{-}{ }^{35} \mathrm{Cl}$ ratio will have decreased ${ }^{35} \mathrm{Cl}(n, p){ }^{35} \mathrm{~S}$ reactions as well as decreased parasitic neutron absorption and ${ }^{36} \mathrm{Cl}$ production.

\subsection{HISTORIC FUEL SALT PREPARATION FACILITIES}

While the feedstock chemicals for MSR fuel salts have been produced in large quantities, only two relatively small test MSRs have ever been operated: the Aircraft Reactor Experiment (ARE) in 1954, and the MSRE from 1965-69. Consequently, no large-scale fuel salt production facilities have ever been built. A description of the processes and equipment used to produce the MSRE's fluoride salts is provided by Shaffer. ${ }^{3}$ Similar information is available for the aircraft nuclear propulsion fluoride fuel preparation facility. ${ }^{4}$ The information presented below describes the ARE and MSRE fuel salt production facilities. Anticipated fuel salt fabrication processes are described in Sections 3 and 4, along with the hazards associated with these processes.

An important limitation of this report derives from the fact that large-scale MSRs have not been previously operated. Some systems and activities can be extrapolated from prior small-scale MSRs, and some can be inferred from larger scale halide salt use. However, there are no direct antecedents for key reactor-specific hazards such as inadvertent criticality during the initial transfer of fuel into the reactor vessel. For example, both the MSRE and ARE cores were initially loaded with flush salt to remove the native oxide layer. ARE staff members then assessed the oxide contamination and decided to keep the flush salt, while MSRE staff members drained the flush salt, cleaned it, and then refilled the fuel circuit. Fissile material concentrate was then gradually added to both circuits to achieve criticality. It does not appear practical to gradually add the much larger quantities of fissile concentrate needed for larger reactors. Commercial-scale reactors may not even perform a flush and fill sequence after emplacement. One potential approach is for smaller integral reactor vessels to (1) be loaded with a slightly subcritical fuel salt mixture at a fuel preparation facility, (2) be transported to the reactor site, and then (3) additional fissile material may be added after installation to achieve criticality. However, the initial fueling process and its attendant hazards remain undetermined.

The fuel and coolant salts for the ARE and MSRE were produced in the uranium processing facilities at the Y-12 National Security Complex in Oak Ridge, Tennessee. Fissile materials were taken from existing US Atomic Energy Commission stockpiles, and non-nuclear chemicals were obtained from commercial sources. The ${ }^{7} \mathrm{Li}$ used in MSRE was taken from the tailings of the Y-12 lithium isotope separation facilities and enriched further before use.

Fluoride and chloride fuel salts are chemically similar to salts used in other industries, and their preparation methods are similar. The most distinctive element of fuel salt preparation derives from the fact that the fuel salt becomes much more corrosive if it contains moisture, sulfur or free oxygen ions. Consequently, the MSR salt synthesis emphasizes the removal of moisture, sulfur and oxygen from commercial grade salts and precursor chemicals. Non-nuclear MSR feedstock chemicals were purchased from commercial suppliers and were re-dried and processed to remove oxides and sulfides before being incorporated into fuel salt.

The basic fuel salt purification process consisted of weighing and mixing the precursor materials and then bubbling a mixture of hydrogen and hydrogen fluoride through the salt until water evolution decreased to the desired level. Hydrogen bubbling was continued to remove residual hydrogen-fluoride and to reduce the structural metal fluorides corroded into the melt by the hydrogen fluoride. This resulted in suspended structural metal particles which were removed by filtering. The melt was then sparged with helium to remove residual hydrogen. 
The equipment configurations for ARE and MSRE fuel salt fabrication were similar. Both took place in the same building. Prior to the preparation of the MSRE salt mixtures, this facility had produced roughly $60,000 \mathrm{~kg}$ of fluoride mixtures of high chemical purity. A flow diagram of the fluoride salt production facilities for the ARE is shown in Figure 1.

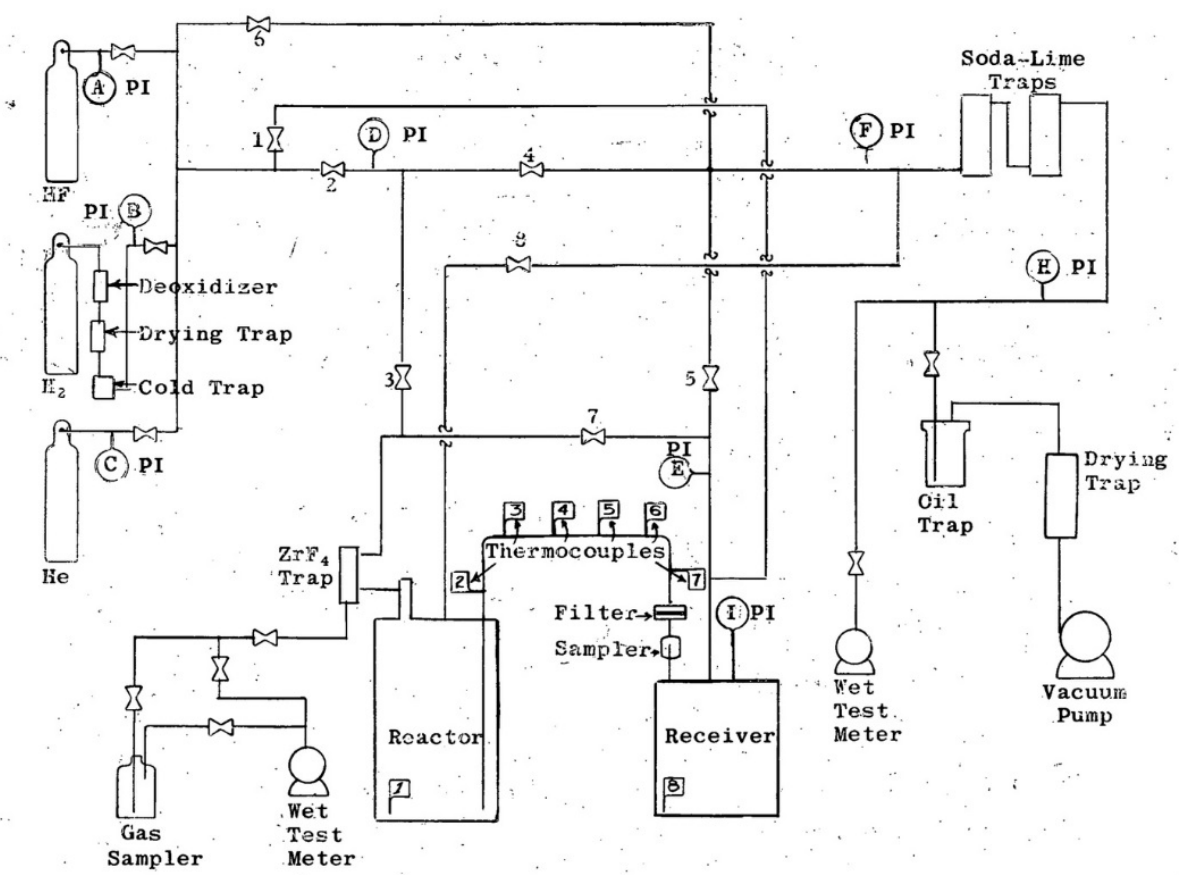

Figure 1. Flow diagram of ARE fluoride salt production facilities (Figure 1 from ORNL-CF-54-6-126).

The MSRE era fluoride salt production facility layout is shown in Figure 2. The fuel salt fabrication was separately enclosed, operated at a negative pressure, and separately ventilated due to beryllium toxicity. The MSRE fuel processing consisted of an arrangement of three cubicles. Cubicle 1 contained equipment for the weighing and mixing the loose fluoride salts. Cubicles 2 and 3 each contained a furnace where the mixture was treated, along with a receiver to which the purified melt was transferred for storage. Specific work areas within the production plant were compartmented and provided with direct exhaust air ducts and filtered makeup air. All exhaust air from the facility was passed through a bank of absolute filters before being discharged outside the building. 


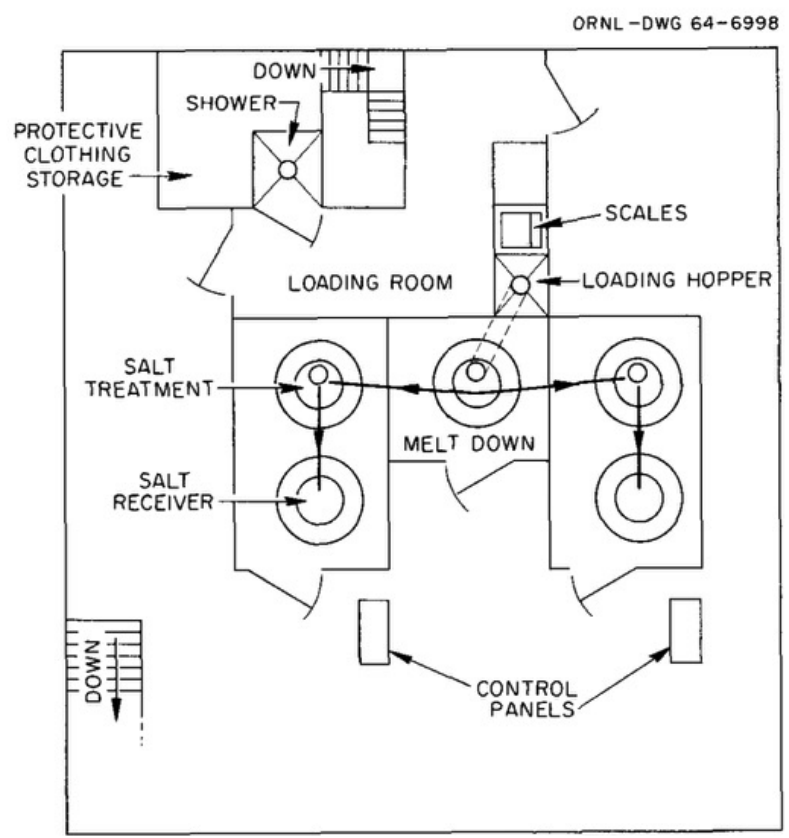

Figure 2. MSRE era fluoride salt production facility layout.

A photo of the fluoride salt production facilities for MSRE (circa 1963) is shown in Figure 3.

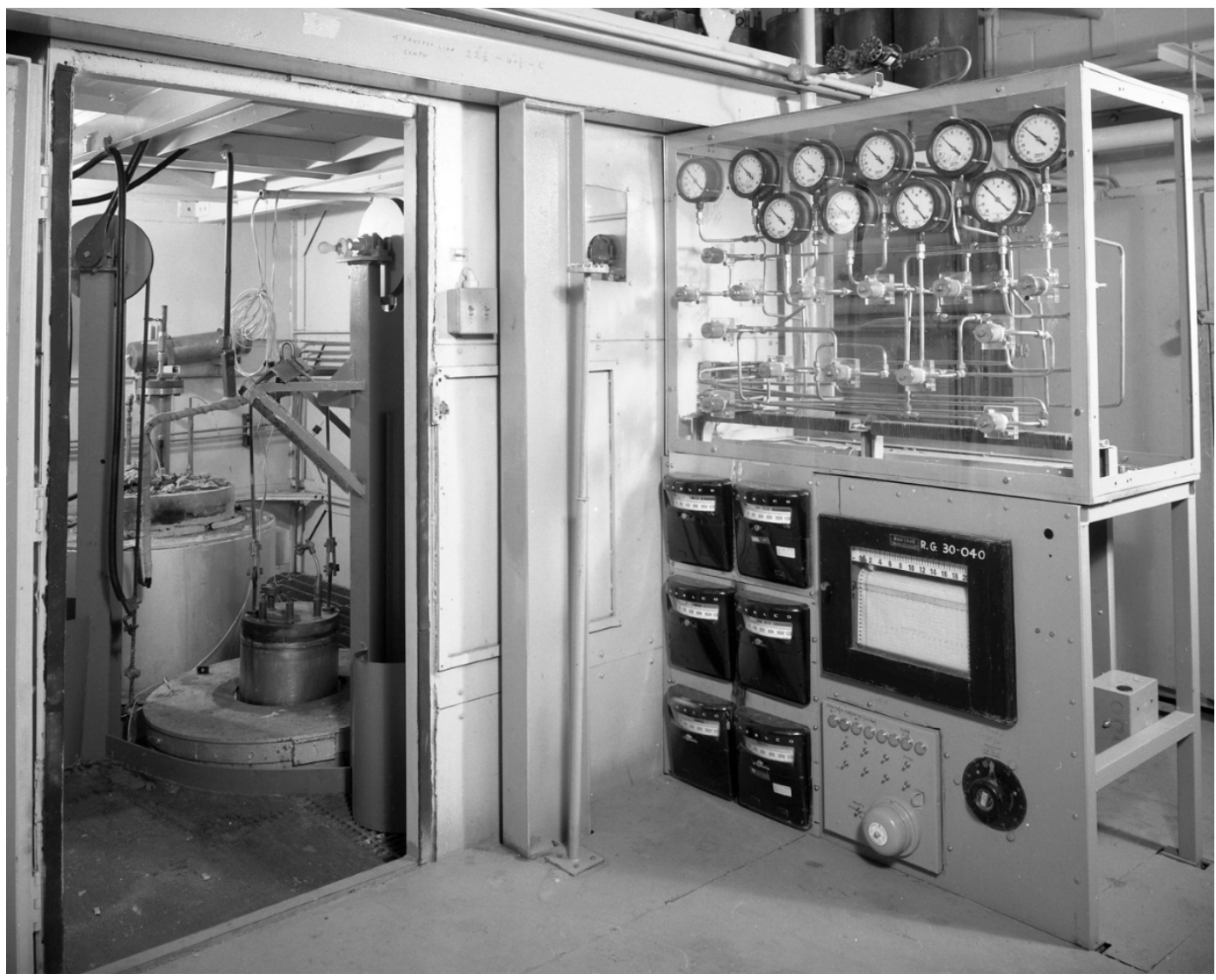

Figure 3. Fluoride production facility, batch-processing unit (ORNL Photo 39428). 
Due to the toxicity that could cause dermal and respiratory sensitization, berylliosis, or cancer via inhalation, operators were isolated from beryllium via a plastic fresh-air suit (Figure 4).

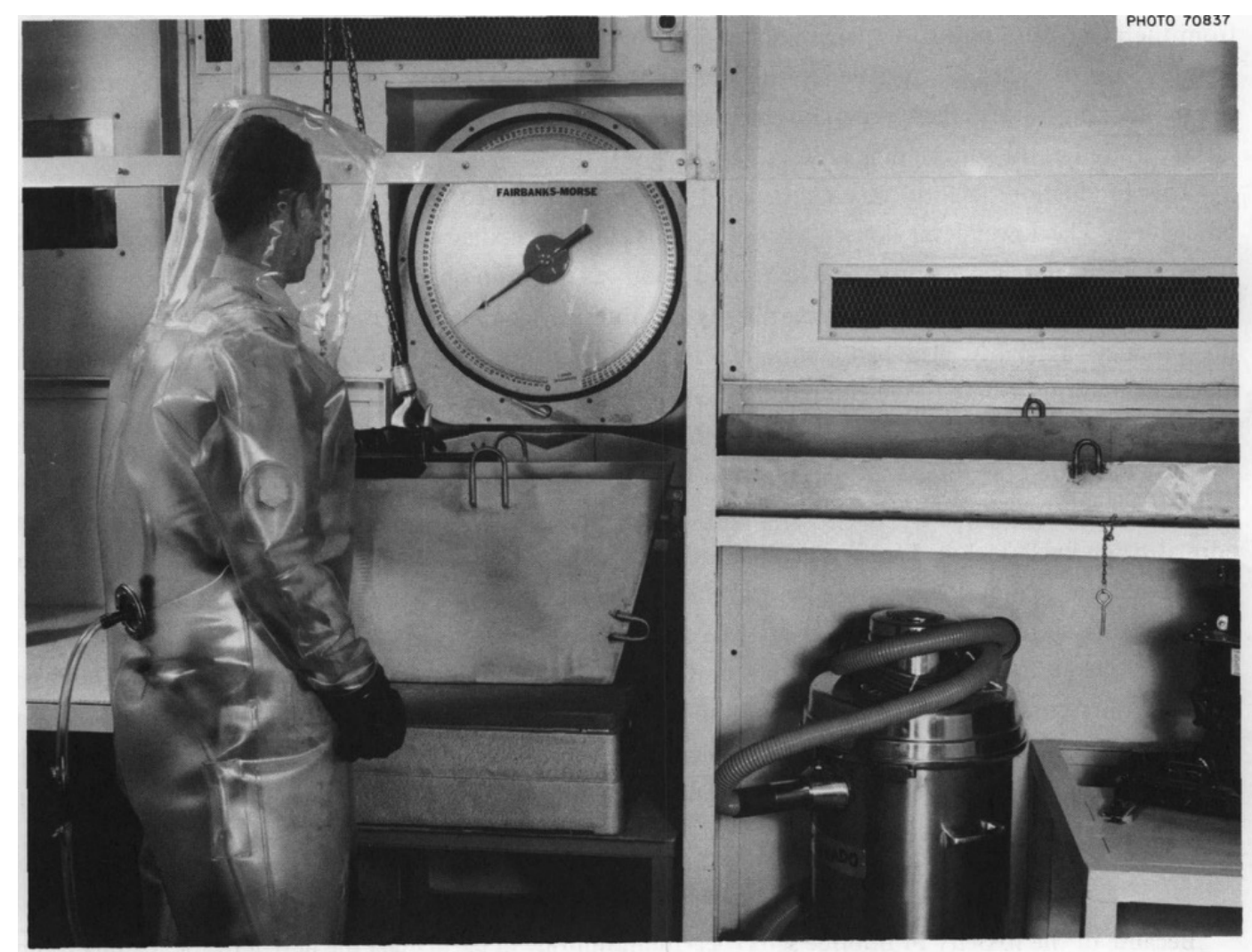

Figure 4. Beryllium salt production; operator wearing a fresh-air suit (ORNL Photo 70837).

\subsubsection{Fuel Loading at ARE}

At the ARE, $\mathrm{Na}_{2} \mathrm{UF}_{6}$ was added to an initially barren mixture of sodium and zirconium fluorides. The procedure to add the ARE fuel involved the successive connection of numerous small concentrate containers to an intermediate transfer pot. The pot was then connected to the fuel system, which injected the concentrate into the pump tank above the liquid level. Since the ARE was not optimized for breeding, its fuel salt contained a higher concentration of uranium. The ARE final fuel mixture consisted of 53.09 mole percent $\mathrm{NaF}, 40.73$ mole percent $\mathrm{ZrF}_{4}$, and 6.18 mole percent $\mathrm{UF}_{4}$, with ${ }^{235} \mathrm{U}$ enriched to 93.4 weight percent. The ARE fuel salt ${ }^{235} \mathrm{U}$ concentration was increased $8.8 \%$ over the course of operations (from $0.383 \mathrm{~g} / \mathrm{cc}$ to $0.416 \mathrm{~g} / \mathrm{cc}$ ) as operational power was increased. ${ }^{5}$ A diagram of the equipment used to introduce fuel concentrate into the ARE fuel system is shown in Figure 5. 


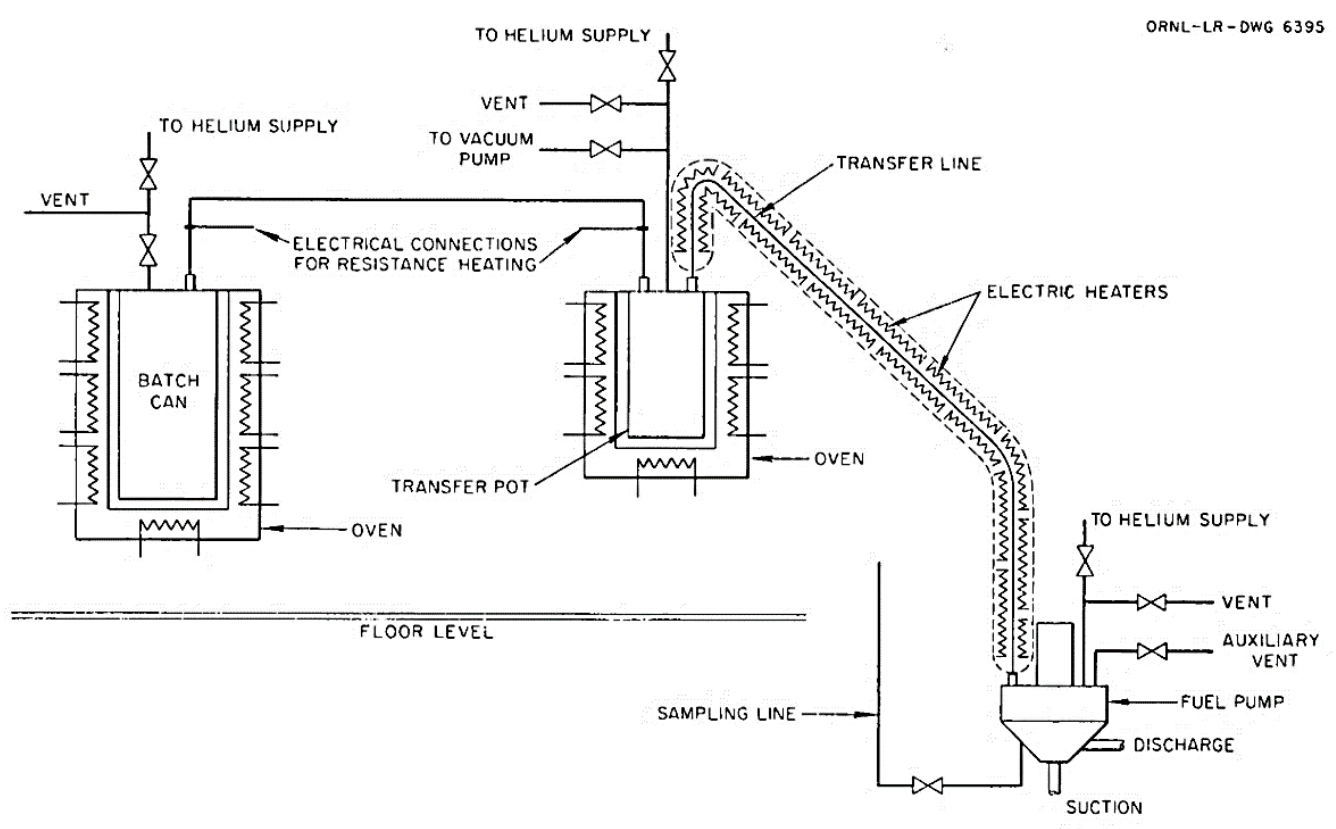

Figure 5. ARE fuel concentrate addition system layout (Figure 4.2 from ORNL-1845).

\subsubsection{Fuel Loading at MSRE}

The MSRE reactor fuel mixture nominally consisted of $65{ }^{7} \mathrm{LiF}, 29.1 \mathrm{BeF}_{2}, 5 \mathrm{ZrF}_{4}$, and $0.9 \mathrm{UF}_{4}(\mathrm{~mole}$ percent). At MSRE, ${ }^{7} \mathrm{LiF}_{-} \mathrm{UF}_{4}(73-27$ mole \%) was separately synthesized and incrementally dissolved into barren carrier salt to start and maintain nuclear operation. Both the MSRE coolant and the flush salt were a binary mixture of 66 mole percent $\mathrm{LiF}$ in $\mathrm{BeF}_{2}$. Initial operation employed 33 weight percent enriched uranium. The operational fuel salt volume was roughly 2,067 liters. All of the lithium used was assayed to be at least $99.99 \%{ }^{7} \mathrm{Li}$. In 1968 , the uranium was removed from the fuel salt and replaced with nearly pure ${ }^{233} \mathrm{U}$. The last few refueling capsules in 1969 contained $\mathrm{PuF}_{3}\left(94\right.$ weight percent $\left.{ }^{239} \mathrm{Pu}\right)$. The capsules were added to the salt as a solid via the sampler-enricher mechanism, Figure 6, which lowered capsules into the pump bowl. ${ }^{6}$ 


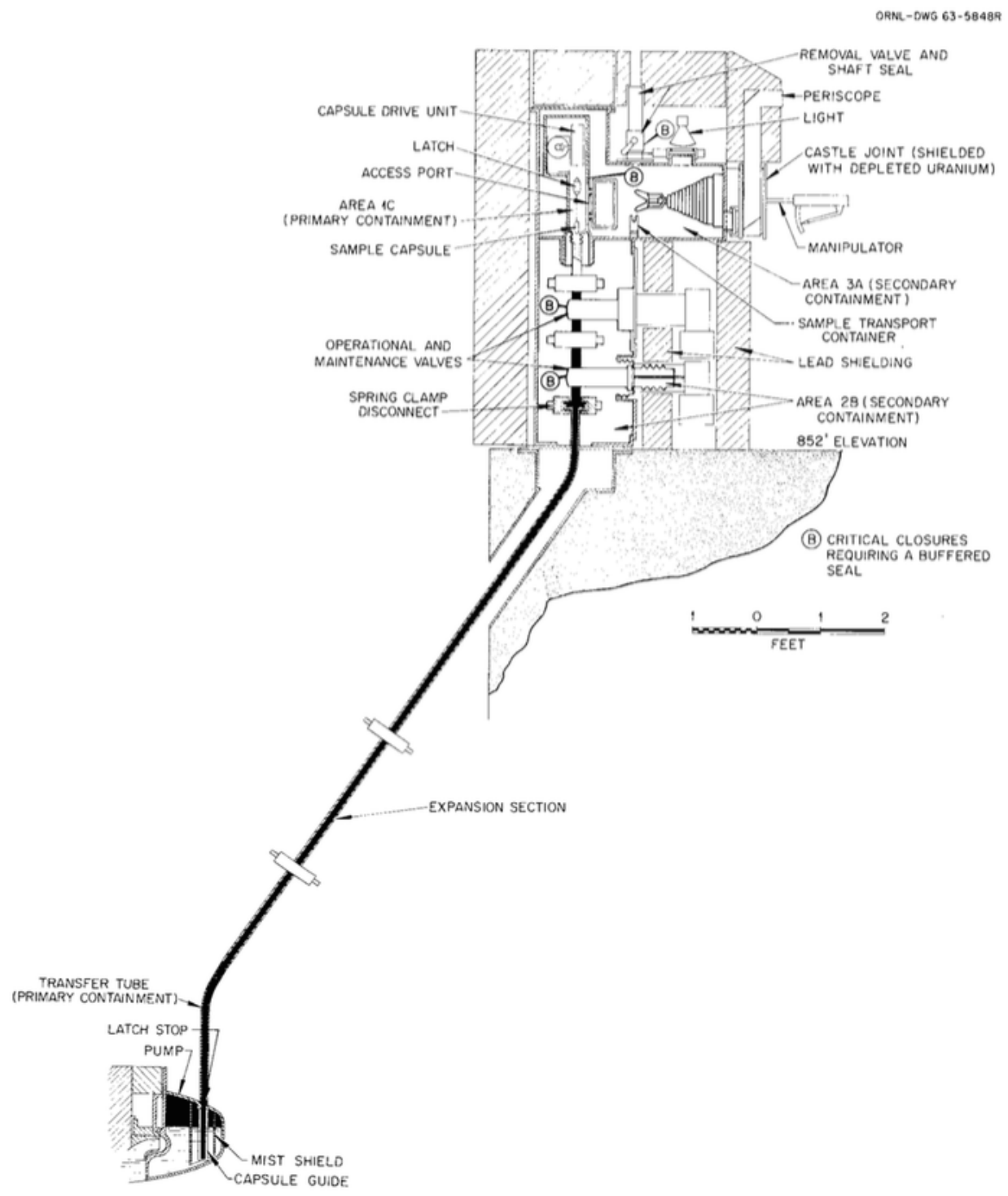

Figure 6. MSRE sampler-enricher mechanism.

The MSRE used different fuel salt capsules for different purposes. Sampling and enriching capsules are shown in Figure $7 .^{7}$ The fuel enriching capsules were constructed from nickel tubing with an outer diameter of $1.91 \mathrm{~cm}$ with hemispherical ends. Each filled capsule contained about $148 \mathrm{~g}$ of salt mixture. Special capsules with zirconium windows were used to expose powdered $\mathrm{PuF}_{3}$, (about $30 \mathrm{~g}$ of plutonium per capsule) to the salt in the pump bowl. ${ }^{8}$ 


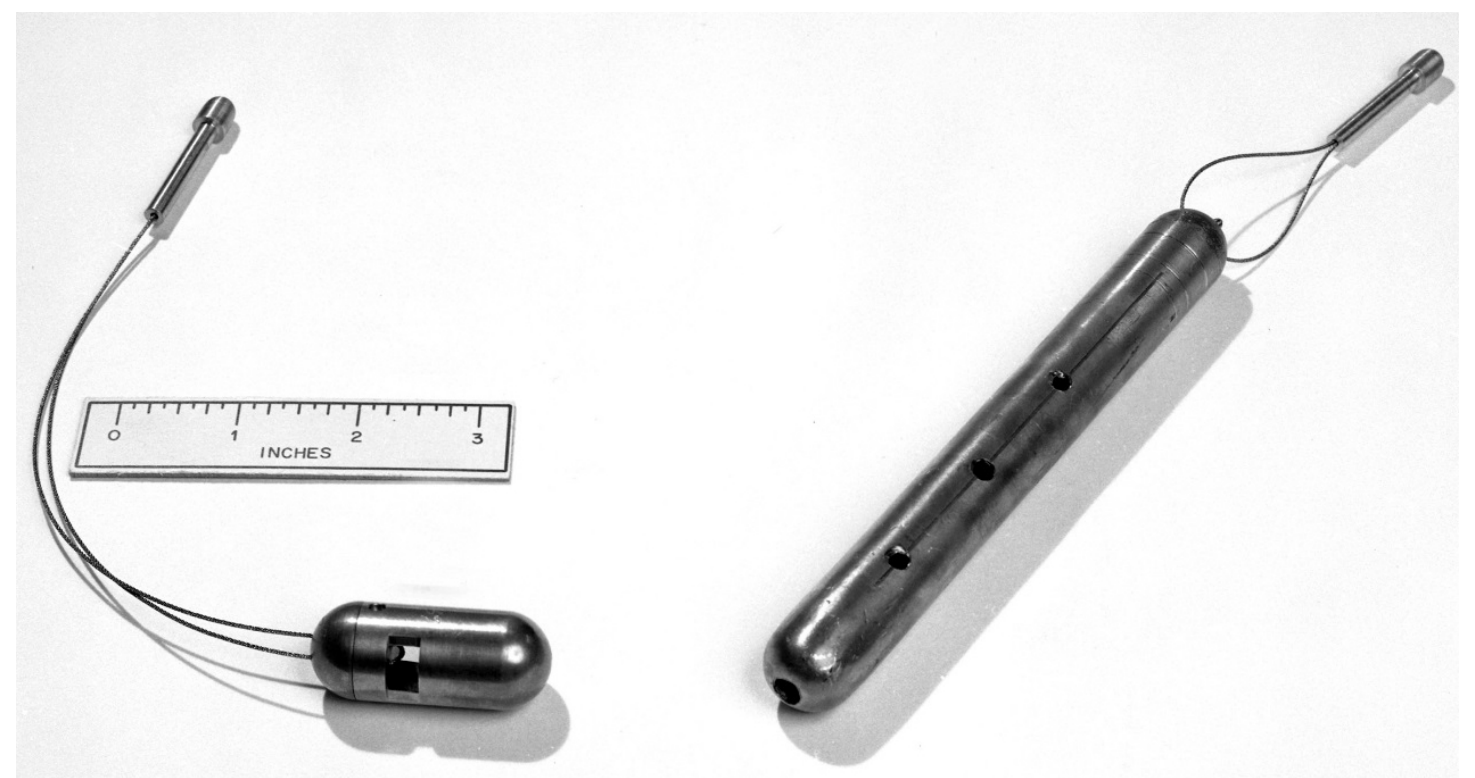

Figure 7. MSRE sampling and enriching capsules (ORNL Photo 71333).

\subsubsection{Stripping Uranium from MSRE Fuel and Flush Salts}

A primary purpose for development of the MSRE was to evaluate the changes in the reactor physics and chemistry that resulted from changing the fissile material type in the fuel salt. Accordingly, the original fuel salt containing a mixture of ${ }^{238} \mathrm{U}$ and ${ }^{235} \mathrm{U}$ was stripped and purified. The uranium was replaced by a smaller amount of nearly pure ${ }^{233} \mathrm{U}$ to provide equivalent reactivity. The facilities and procedures that were used to accomplish the uranium removal and fuel salt purification (oxide removal) are described in ORNL-TM-2578, ${ }^{9}$ which is the basis for the information in the following discussion.

The MSRE fuel salt processing facility was located in a small hot-cell within the MSRE building. The plant's first use was to remove the oxide from the flush salt $(115 \mathrm{ppm})$ that was initially circulated in the MSRE fuel circuit to strip the native oxide layer from the structural alloy surfaces.

The uranium recovery process consisted of fluorine sparging to volatilize the uranium, followed by decontamination of the gas stream with a $\sim 400^{\circ} \mathrm{C} \mathrm{NaF}$ bed, where chromium fluoride and most fission products were removed, and absorption of the $\mathrm{UF}_{6}$ on $93^{\circ} \mathrm{C} \mathrm{NaF}$ beds. The excess fluorine was removed using an aqueous scrubber. The corrosion product fluorides were reduced to the metals, which were filtered from the salt before the salt was returned to the reactor system. The flush salt contained $6.5 \mathrm{~kg}$ of uranium, and the fuel salt contained about $216 \mathrm{~kg}$ of uranium. Reduction and filtration produced carrier salt containing fewer impurities than the original salt. The recovered uranium was decontaminated from FPs by gross gamma and gross beta decontamination factors of $8.6 \times 10^{8}$ and $1.2 \times 10^{9}$, respectively. Identifiable uranium losses were less than $0.1 \%$. Since the first-phase MSRE fuel salt contained $66 \mathrm{wt} \%$ ${ }^{238} \mathrm{U}$ assay, a significant amount of ${ }^{239} \mathrm{Pu}$ was produced. At the time of processing, the plutonium concentration in the fuel salt was calculated to be $112 \mathrm{ppm}(560 \mathrm{~g})$. After fluorination, reduction, and return of the salt batch to the reactor drain tank, five salt samples that were withdrawn showed an average concentration of $110 \mathrm{ppm}$, demonstrating that the plutonium was not removed by the uranium stripping operation.

The flowsheet for the stripping process is shown in Figure 8. 


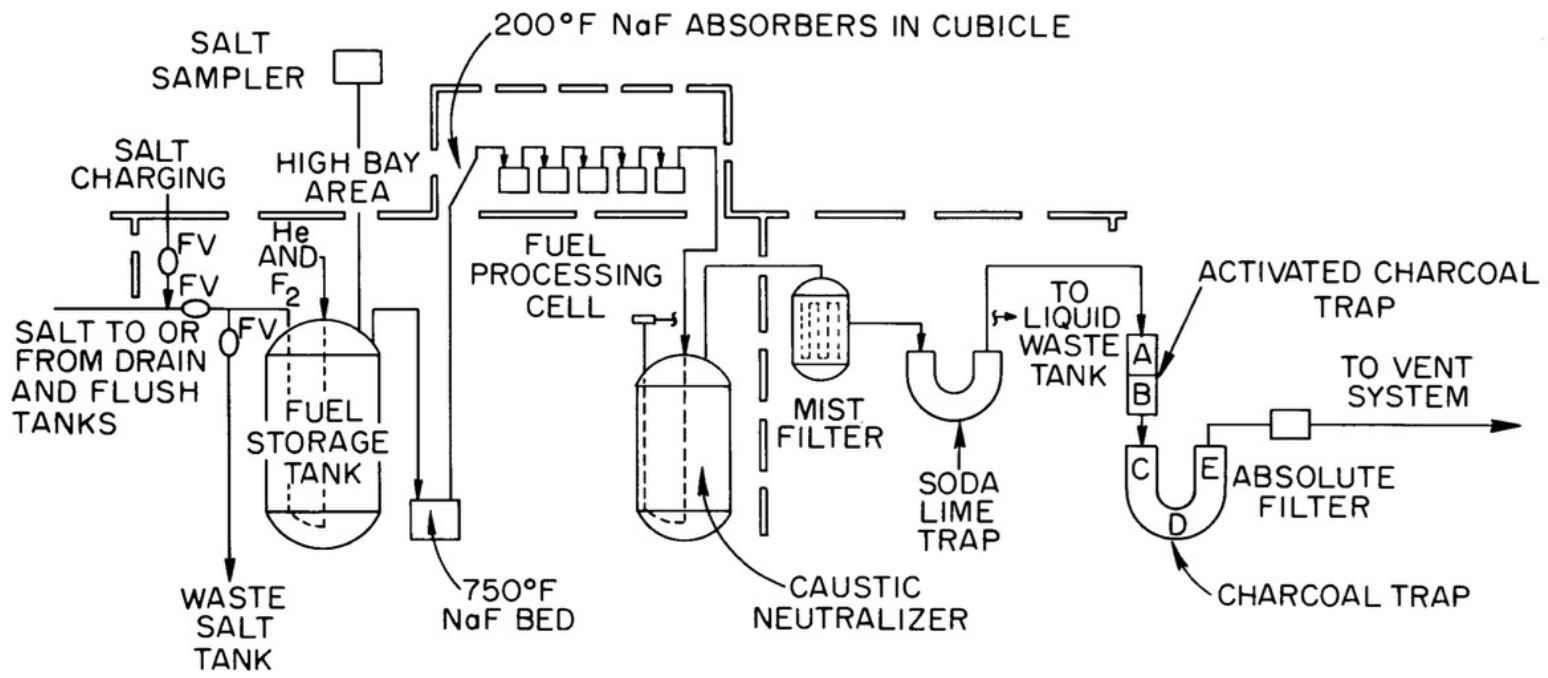

Figure 8. MSRE Uranium Stripping fuel processing system flowsheet.

Most of the processing equipment is located in the fuel processing cell shown in Figure 9. The processing cell $\left(3.96 \mathrm{~m} \times 3.96 \mathrm{~m} \times 5.18 \mathrm{~m}\right.$ deep) contains the fuel storage tank (fluorinator), the $400^{\circ} \mathrm{C} \mathrm{NaF}$ trap, the caustic scrubber, two remotely operated air valves, three salt freeze valves, and the blower for the absorber cubicle.

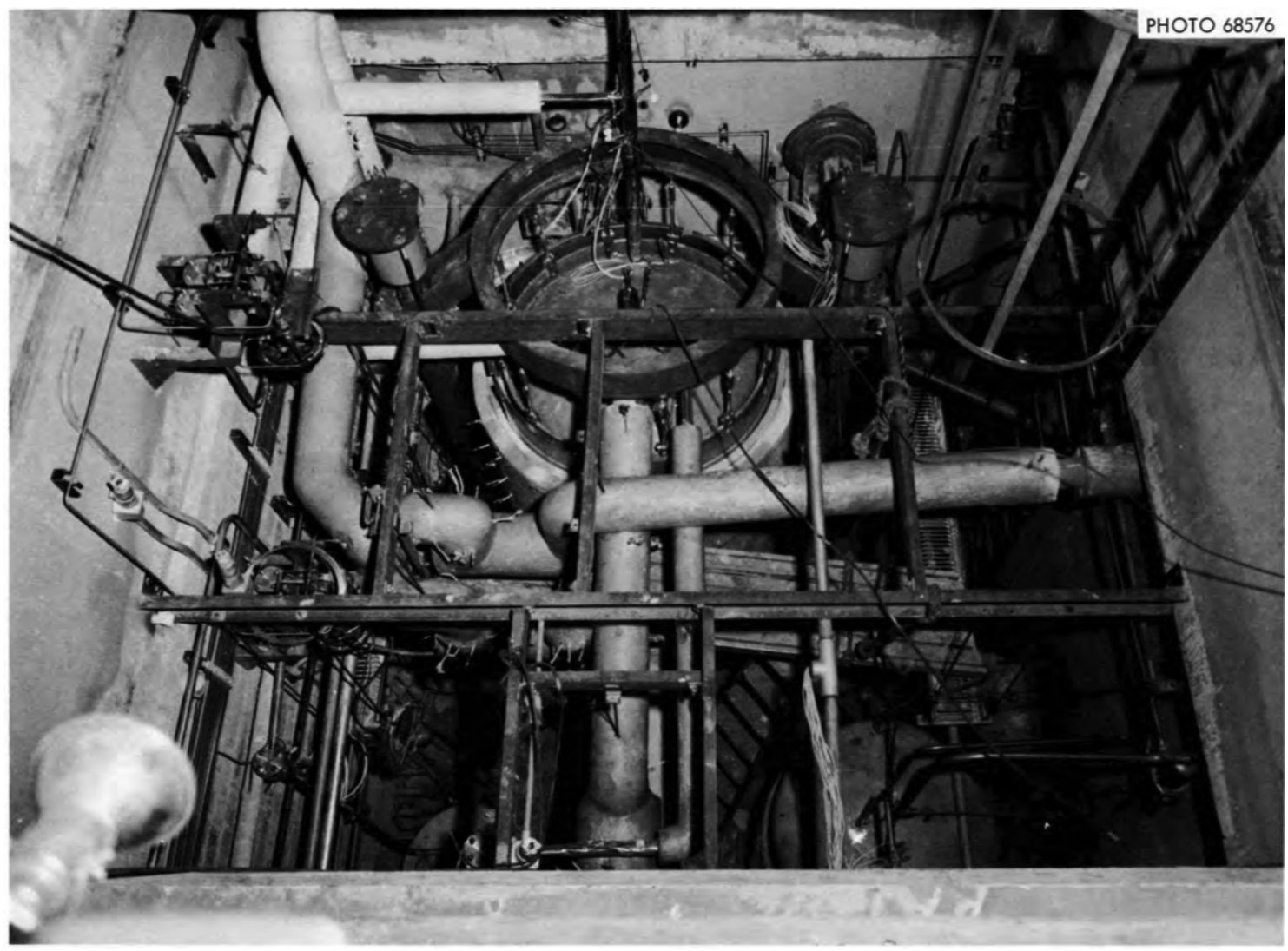

Figure 9. MSRE fuel processing hot cell. 


\section{NON-REACTOR SITE FUEL SALT PROCESSES AND HAZARDS}

This section describes the non-reactor fuel salt production processes and operations necessary to prepare the components of fuel salts, including the non-radioactive carrier salts and salts of fissile and fertile materials. Transportation of fuel salt to the reactor is also discussed.

\subsection{SALT COMPONENT SYNTHESIS}

\subsubsection{Non-actinides}

The carrier salts are common industrial salts, such as $\mathrm{NaCl}, \mathrm{NaF}, \mathrm{MgCl}_{2}, \mathrm{ZrF}_{4}, \mathrm{ZrCl}_{2}$, and LiF. Beryllium metal, widely used in electric devices, is prepared from $\mathrm{BeF}_{2}$. Also, lithium would need to be isotopically separated to be usable in fuel salt, as the neutron absorption cross section of ${ }^{6} \mathrm{Li}$ is too high for use in core. MSRE flush and coolant salts had a ${ }^{7} \mathrm{Li}$ abundance ranging from 99.991 to $99.994 \%$. The materials are anticipated to be commercially procured by the fuel salt synthesizer.

The lithium hydroxide-mercury amalgam column exchange-based (Colex) separation process was used in the United States in the $1950-60$ s on a large scale to separate ${ }^{6} \mathrm{Li}$ from ${ }^{7} \mathrm{Li}$ for the thermonuclear weapons program. The MSR program made use of the ${ }^{7} \mathrm{Li}$ resulting from the process that was not useful for weapons. This ${ }^{7} \mathrm{Li}$ was further separated again using the Colex process. As industrial-scale mercury usage presents large environmental contamination and health risks, alternative lithium isotope separation processes based on electromigration are being evaluated to support MSR and fusion technologies. Other methods involve selective capture of lithium isotopes with a crown ether, either presented as an immobile phase on a resin, or carried in an immiscible organic phase that is contacted by the aqueous lithium hydroxide phase.

While natural isotopic abundance chlorine could be used in fuel salt, using ${ }^{37} \mathrm{Cl}$ salts would improve the reactor neutron economy and decrease the production of ${ }^{36} \mathrm{Cl}$ (long half-life beta emitter) and ${ }^{35} \mathrm{~S}$ that causes corrosion. Isotopically separated chlorine is not available in large quantities commercially, as no large-scale use for specific chlorine isotopes has been established. However, several technologies that would be scalable to large size have been demonstrated in laboratory settings. Gas- phase isotopic separation for chlorine was first demonstrated at the laboratory scale in 1939 by thermal diffusion of $\mathrm{HCl}$ with several attempts into the 1950 s to increase the quantity produced by this method. ${ }^{10,11}$ Liquid-phase thermal diffusion is also a well understood process for chlorine isotope separation. ${ }^{12}$ In this process, the isotope separation was undertaken using $\mathrm{CCl}_{4}$ as a stable chlorine-bearing compound. The process was carried out in a metal vessel under a pressure of 5 bar to ensure that the $\mathrm{CCl}_{4}$ remained liquid. Chloroform and other impurities must be considered in the separation process. Room-temperature anion exchange chromatography has also been demonstrated for chlorine isotope separation. ${ }^{13}$ Elution of chlorine from the column is done by passing $\mathrm{AgNO}_{3}$ through the bed. Recently, significant chlorine isotope separation has been shown during $\mathrm{NaCl}$ crystallization under magnetic fields of $20-80 \mathrm{mT}$. ${ }^{14}$ All of the proposed techniques employ readily available materials at temperatures less than $100^{\circ} \mathrm{C}$, so they could be performed with commonly available tools and materials.

The primary purpose for salt purity requirements is to minimize salt corrosivity. The fission process produces comparatively large amounts of impurities in the fuel salt, somewhat contradicting the reactor physics rationale for high purity feedstock materials. Halide salts are hygroscopic and must be handled under an inert atmosphere during synthesis, mixing, and handling. Samples of the MSRE fuel mixture and (less frequently) the coolant mixture were analyzed routinely during all periods when salts were circulated in the reactor. On each occasion of its use, the flush salt also was analyzed. The concentrations of the salt constituents, oxide contaminants, and FP species were monitored on a continuing basis. ${ }^{15}$ Blankenship et al., describe the methods of salt testing before and during operation. ${ }^{16}$ 
Salt samples were taken to assess purity just before the reactor was loaded. Results for the average of 39 samples are given in Table 2 below, with the greatest variability in the trace elements. Before criticality, the MSRE fuel and coolant salt systems were heated to $650^{\circ} \mathrm{C}$ and purged with $\mathrm{HF} / \mathrm{H}_{2}$ in helium to remove moisture. The flush salt was also evaluated spectrochemically for $\mathrm{Al}, \mathrm{B}, \mathrm{Bi}, \mathrm{Ca}, \mathrm{Cu}, \mathrm{Mg}, \mathrm{Mn}, \mathrm{Na}$, $\mathrm{Pb}, \mathrm{Si}, \mathrm{Sn}$, and $\mathrm{Zr}$, and the $\mathrm{KBrF}_{4}$ method was used to measure the oxygen concentration.

Table 2. Table of analyses of $\mathrm{LiF}_{-} \mathrm{BeF}_{2}$ for MSRE coolant and flush salts (Thoma ORNL-4658).

\begin{tabular}{lcl}
\hline \multicolumn{1}{c}{ Element/isotope } & amount & \multicolumn{1}{c}{ units } \\
\hline Coolant Salt & & \\
Lithium-7 & $99.992 \pm 0.001$ & Isotopic purity (\%) \\
Lithium & $12.9 \pm 0.4$ & $\mathrm{Wt} \%$ \\
Beryllium & $9.8 \pm 0.2$ & $\mathrm{Wt} \%$ \\
Fluorine & $77.1 \pm 0.3$ & $\mathrm{Wt} \%$ \\
Chromium & $16 \pm 11$ & $\mathrm{ppm}$ \\
Nickel & $39 \pm 35$ & $\mathrm{ppm}$ \\
Iron & $121 \pm 33$ & $\mathrm{ppm}$ \\
Oxygen & 75 & $\mathrm{ppm}$ \\
& & $(\mathrm{by} \mathrm{KBrF}-$ three samples) \\
Flush $\mathrm{Salts}$ & & \\
& (ranges from analysis of 22 & \\
$\mathrm{Al}, \mathrm{Bi}, \mathrm{Ca}, \mathrm{Pb}, \mathrm{Zr}$ & samples) & \\
$\mathrm{Al}, \mathrm{Bi}, \mathrm{Cu}, \mathrm{Mg}, \mathrm{Na}, \mathrm{Pb}, \mathrm{Si}, \mathrm{Sn}, \mathrm{Zr}$ & & $\mathrm{ppm}$ \\
$\mathrm{B}, \mathrm{Bi}, \mathrm{Cu}, \mathrm{Mg}, \mathrm{Mn}, \mathrm{Pb}$ & $100-1500$ & $\mathrm{ppm}$ \\
\hline
\end{tabular}

Oxides are likely the most problematic contaminant. Oxide analysis in chloride salts is accomplished by titration. The analysis is more difficult in fluoride salts. The standard method is to use the reagent $\mathrm{KBrF}_{4}$, but MSRE staff found that the salt absorbed water in between sampling and analysis, making the method inaccurate.${ }^{17}$ An inert gas-fusion method was also considered. ${ }^{18}$ However, the staff at MSRE chose the reaction of

$$
\mathrm{O}^{2-}+2 \mathrm{HF}(\mathrm{g}) \Leftrightarrow \mathrm{H}_{2} \mathrm{O}+2 \mathrm{~F}^{-}
$$

as the means by which to measure oxygen content in the salt, as this was considered to be the method least affected by externalities, although not the most sensitive. In this method, the salt is heated to $700^{\circ} \mathrm{C}$, and the water evolved or the hydrogen fluoride (HF) consumed can then be measured. The water can be measured offline by Karl-Fischer titration or online with a moisture analyzer. HF can be measured after being captured in a downstream trap. Little development of oxide measurements in fluoride salts has been done since MSRE operation.

\subsubsection{Actinides}

\subsubsection{Uranium from enrichment plant}

All commercial uranium enrichment plants use $\mathrm{UF}_{6}$ as the feed material, so that is the likely starting compound for producing molten salt fuel containing enriched uranium. There are no unique hazards introduced into the enrichment plants related to using their product to produce molten salt fuel. 


\subsubsection{UF Uroduction $_{4}$ Produs}

Producing low enrichment $\mathrm{UF}_{4}$ salt for an MSR involves many of the same processes currently used when producing $\mathrm{UO}_{2}$ fuel for LWRs: uranium is mined, purified, converted to $\mathrm{UF}_{6}$, transported to an enrichment facility, enriched in ${ }^{235} \mathrm{U}$, and then transported to a fuel fabrication facility. When producing $\mathrm{UO}_{2}$ for an $\mathrm{LWR}$, the $\mathrm{UF}_{6}$ is converted to $\mathrm{UO}_{2}$ by one of several available processes, and then it is used to produce fuel pellets. All these processes are performed commercially on a large scale, and the hazards are well known. Many potential processes exist for producing $\mathrm{UF}_{4}$ for an MSR, which are described later in this report, but the most common process currently used involves reacting $\mathrm{UO}_{2}$ with $\mathrm{HF}$ in a kiln. This is the first step for producing $\mathrm{UF}_{6}$ from natural uranium oxides prior to enrichment, so the chemical hazards would be the same. The criticality concerns for producing and handling enriched $\mathrm{UF}_{4}$ would be the same as for producing $\mathrm{UO}_{2}$ from enriched $\mathrm{UF}_{6}$ at a fuel fabrication facility.

The primary chemical hazard for producing $\mathrm{UF}_{4}$ is the HF gas, which is toxic and corrosive. The Occupational Safety and Health Administration (OSHA) permissible exposure limit (PEL) for HF is 2.5 $\mathrm{mg} / \mathrm{m}^{3}$ (as F), over 8 hours. Fluorine gas, which is used to produce $\mathrm{UF}_{6}$ from $\mathrm{UF}_{4}$, is more toxic, with a recommended PEL of $0.2 \mathrm{mg} / \mathrm{m}^{3}$, so the current $\mathrm{UF}_{6}$ production facilities are more chemically hazardous than facilities that would only produce $\mathrm{UF}_{4} . \mathrm{UF}_{4}$ is much more chemically stable than $\mathrm{UF}_{6}$, and it has an insignificant vapor pressure, a very slight solubility in water, and reacts very slowly with moisture in the air. $\mathrm{UF}_{6}$ has a moderate vapor pressure $\left(109 \mathrm{~mm} \mathrm{Hg} @ 20^{\circ} \mathrm{C}\right)$ and reacts vigorously with water, so the product from a $\mathrm{UF}_{4}$ production facility is less dangerous than $\mathrm{UF}_{6}$ product.

Several alternate processes for converting enriched $\mathrm{UF}_{6}$ to $\mathrm{UF}_{4}$ without first converting the $\mathrm{UF}_{6}$ to $\mathrm{UO}_{2}$ have been tested on a small scale. These processes would be much more efficient in terms of HF usage and would produce less fluoride waste; however, only the carbon tetrachloride reduction and hydrogen reduction methods have been used on a commercial scale. ${ }^{19}$ These processes could also be used to produce $\mathrm{UF}_{4}$ from depleted $\mathrm{UF}_{6}$, which is the planned fuel for a few MSR designs.

Carbon Tetrachloride Process: The reduction of $\mathrm{UF}_{6}$ with $\mathrm{CCl}_{4}$ has been described by Nairn et al. $1958,{ }^{20}$ Collins et al. 1960, ${ }^{21}$ and Galkin et al. $1961 .{ }^{22}$ The reaction takes place in the condensed phase, with heating to $120-150^{\circ} \mathrm{C}$ to start the reaction. The reaction stoichiometry has a molar ratio $\mathrm{CCl}_{4}: \mathrm{UF}_{6}$ of $2: 1$ and may be written as

$$
\mathrm{UF}_{6}(s)+2 \mathrm{CCl}_{4}(l) \rightarrow \mathrm{UF}_{4}(s)+\mathrm{Cl}_{2}(g)+2 \mathrm{CCl}_{3} \mathrm{~F}(g) .
$$

Gaseous effluents include chlorine $\left(\mathrm{Cl}_{2}\right)$, freons $\left(\mathrm{CCl}_{\mathrm{x}} \mathrm{F}_{(4-\mathrm{x})}\right)$, and excess carbon tetrachloride $\left(\mathrm{CCl}_{4}\right)$. The reaction is exothermic, and if the reactants are confined in a batch reactor, the pressure increases to $\sim 200$ psi ( $\sim 14$ bar) with the production of gaseous products and the temperature increases slightly. Batch reactors are not the only way to implement this process, but they do tend to make material accountancy easier.

$\mathrm{CCl}_{4}$ is a suspected human carcinogen which may cause liver and kidney damage and central nervous system depression. The OSHA PEL is $10 \mathrm{ppm}$ time-weighted average (TWA), and $200 \mathrm{ppm}$ is immediately dangerous to life and health (IDLH). The off-gas is corrosive due to the $\mathrm{Cl}_{2}$ formed, which is also toxic (PEL TWA for 8 hours is $0.5 \mathrm{ppm}$ ).

NOx Process: The Goodyear Atomic Corporation investigated reactions between $\mathrm{UF}_{6}$ and nitrogen oxides $\left(\mathrm{NO}_{\mathrm{X}}\right)$ to prepare reduced uranium compounds in the late $1950 \mathrm{~s}$ and early $1960 \mathrm{~s} .{ }^{23,24,25}$ A simple two-step dry process can be used to make $\mathrm{UF}_{4}$. The initial reaction between $\mathrm{UF}_{6}$ and $\mathrm{NO}_{\mathrm{X}}$ forms a binary adduct consisting of a stable powdery solid. This intermediate is subsequently reduced to $\mathrm{UF}_{4}$ by reaction with hydrogen $\left(\mathrm{H}_{2}\right)$ or carbon monoxide $(\mathrm{CO})$. Examples of the reactions with NOx are shown below. 
The reaction of contacting solid or gaseous $\mathrm{UF}_{6}$ with nitric oxide $(\mathrm{NO})$, produces nitrosylium hexafluorouranate. In excess $\mathrm{NO}$, the reaction takes place rapidly at temperatures between 25 and $60^{\circ} \mathrm{C} .{ }^{21}$ The heat of the reaction is low. The product is a whitish-green solid with low vapor pressure $(<0.001$ bar at $25^{\circ} \mathrm{C}$ ).

$$
\mathrm{UF}_{6}(s \text { or } g)+\mathrm{NO}(g) \rightarrow \mathrm{NOUF}_{6}(s) \text {. }
$$

Another intermediate, nitrylium hexafluorouranate, also is made by reacting solid or gaseous $\mathrm{UF}_{6}$ with liquid or gaseous nitrogen dioxide $\left(\mathrm{NO}_{2}\right)$. The reaction is rapid, even at less than $0^{\circ} \mathrm{C}$, and occurs instantaneously between $25-60^{\circ} \mathrm{C}$, with a low heat of reaction:

$$
\mathrm{UF}_{6}(\text { s or } g)+\mathrm{NO}_{2}(l \text { or } g) \rightarrow \mathrm{NO}_{2} \mathrm{UF}_{6}(s)
$$

The nitrylium hexafluorouranate product is a yellowish-white solid with very low vapor pressure at $25^{\circ} \mathrm{C}$. Under excess $\mathrm{NO}_{2}$ or dinitrogen tetraoxide $\left(\mathrm{N}_{2} \mathrm{O}_{4}\right)$ the $\mathrm{NO}_{2} \mathrm{UF}_{6}$ converts to $\mathrm{NOUF}_{6}$.

$$
\mathrm{NO}_{2} \mathrm{UF}_{6}(s)+\mathrm{N}_{2} \mathrm{O}_{4}(l \text { or } g) \rightarrow \mathrm{NOUF}_{6}(s)+\mathrm{N}_{2} \mathrm{O}_{5}(\text { l or } g) \text {. }
$$

The dinitrogen pentaoxide $\left(\mathrm{N}_{2} \mathrm{O}_{5}\right)$ byproduct will convert to $\mathrm{NO}_{2} / \mathrm{N}_{2} \mathrm{O}_{4}$ and $\mathrm{O}_{2}$.

In the case of either mechanism, reaction of the $\mathrm{NOUF}_{6}$ adduct with hydrogen gas produces $\mathrm{UF}_{4}$ at $250^{\circ} \mathrm{C}$ to $350^{\circ} \mathrm{C}$ :

$$
\mathrm{NOUF}_{6}(s)+\mathrm{H}_{2}(g) \rightarrow \mathrm{UF}_{4}(s)+2 \mathrm{HF}(g)+\mathrm{NO}(g) .
$$

$\mathrm{NO}$ and $\mathrm{NO}_{2}$ are both toxic, with PEL TWAs for 8 hours of $25 \mathrm{ppm}$ and $0.2 \mathrm{ppm}$, respectively. The HF in the off gas is corrosive and toxic.

HBr, HCl or HI Process: $\mathrm{UF}_{6}$ will react with the hydrogen halides to produce $\mathrm{UF}_{4}$ and/or $\mathrm{UF}_{5}$ at moderate temperatures $\left(<100^{\circ} \mathrm{C}\right.$ for $\mathrm{HBr}$ and $\mathrm{HI}$, and $\sim 300^{\circ} \mathrm{C}$ for $\left.\mathrm{HCl}\right) \cdot{ }^{26,}{ }^{27} \mathrm{Using} \mathrm{HBr}$, the reaction is

$$
\mathrm{UF}_{6}(\mathrm{~g})+2 \mathrm{HBr}(\mathrm{g}) \rightarrow \mathrm{UF}_{4}(\mathrm{~s})+2 \mathrm{HF}(\mathrm{g})+\mathrm{Br}_{2}(\mathrm{~g})
$$

The off gas would be toxic and corrosive. $\mathrm{Br}_{2}$ has a PEL TWA for 8 hours of $0.1 \mathrm{ppm}$.

Hydrogen Process: $\mathrm{UF}_{6}$ will react with the hydrogen gas to form $\mathrm{UF}_{4}$ and $\mathrm{HF}$, but only at very high temperatures $\left(1,200-1,700^{\circ} \mathrm{C}\right) .{ }^{28}$ The reaction is exothermic, but only after the $\mathrm{UF}_{4}$ is condensed from the vapor, which occurs at about $1,300^{\circ} \mathrm{C}$. This process involves a very simple reaction with only one byproduct (HF), but the required temperature is much higher than for the alternate processes, and it must be tightly controlled. The HF in the off gas would be toxic and corrosive.

$$
\mathrm{UF}_{6}(\mathrm{~g})+\mathrm{H}_{2}(\mathrm{~g}) \rightarrow \mathrm{UF}_{4}(\mathrm{~s})+2 \mathrm{HF}(\mathrm{g})
$$

Currently it is not clear which of these processes would be chosen for large-scale production of $\mathrm{UF}_{4}$ from $\mathrm{UF}_{6}$, although the hydrogen reduction was used in the past. Both the NOx and $\mathrm{HBr}$ processes operate at mild conditions and should be relatively easy to run. Both nitrogen and oxygen concentrations must be kept very low in the molten salt fuel, which would be a concern if the NOx process were used. 
Different synthetic pathways to halogenated salts have the potential to have different contaminants of concern. For instance, the reduction of $\mathrm{UF}_{6}$ to $\mathrm{UF}_{4}$ through reaction with $\mathrm{CCl}_{4}$ may leave residual chlorine or chlorinated byproducts in addition to carbon. Halogenation of an oxide may leave residual oxide, as observed in MSRE fuel. Reduction of $\mathrm{UF}_{6}$ with $\mathrm{NO}$ or $\mathrm{NO}_{2}$ could leave residual nitrates. None of these results are desirable in salt systems, although additional purification steps are always possible to mitigate these issues. In the case of excess halogen, heating and sparging with inert gas is a method to remove residual acid gases. Oxides can be removed from fluorides by bubbling with $\mathrm{HF} / \mathrm{H}_{2}$. A number of methods have been identified to remove oxides from uranium chlorides. In all these cases, the reactive gases are hazardous, and processing facilities must provide the correct inert atmosphere and chemical containment required for safety and efficacy.

\subsubsection{3 $\mathrm{UCl}_{3}$ Production via High Temperature Techniques}

Chloride-based reactors have been designed to operate with uranium $\left(\mathrm{UCl}_{3}\right)$ or transuranic $\left(\mathrm{PuCl}_{3}, \mathrm{AmCl}_{3}\right.$, and $\mathrm{CmCl}_{3}$ ) fuels that are dissolved in a mixture of alkali or alkaline-earth chlorides, including $\mathrm{NaCl}$, $\mathrm{MgCl}_{2}$, and $\mathrm{CaCl}_{2}$. The production of $\mathrm{UCl}_{3}$ comes from the precursor $\mathrm{UCl}_{4}$, often from reduction in hydrogen. It will also be produced if $\mathrm{UCl}_{4}$ contacts heated metals. $\mathrm{UCl}_{4}$ can be made by chlorinating uranium oxides or uranium fluorides, namely $\mathrm{UF}_{6}$ and $\mathrm{UF}_{4} \cdot{ }^{29}$ Chlorinating agents include $\mathrm{CCl}_{4}$, hexachloropropene, $\mathrm{Cl}_{2}$, phosgene, or mixtures of $\mathrm{CO}$ with $\mathrm{Cl}_{2}{ }^{30}$ Most of the information on uranium chloride chemistry presented here comes from a review written by Larsen (1946) ${ }^{29}$ as much of the publicly available knowledge dates from the era leading up to and through World War II.

Traditional methods of $\mathrm{UCl}_{4}$ manufacturing involve a gas phase reaction or, it is accomplished by reaction in the liquid phase. These production routes require feedstock $\mathrm{UO}_{2}$ or a supply of $\mathrm{UF}_{6}$, the latter of which is currently at a surplus in the United States. The activity of the oxides to halogenation depends on the purity, oxidation state, and particle size of the powder. Freshly reduced oxides can be pyrophoric. Gasphase halogenation at high temperatures gives a dense, crystalline product. Liquid phase reactions go further to completion, as they are often autocatalytic.

Preparation of $\mathrm{UCl}_{4}$ from metallic uranium is possible through combustion in chlorine at $250-300^{\circ} \mathrm{C}$ or through reaction with $\mathrm{HCl}$, phosgene, or methyl chloride. The metal is converted to the hydride before combustion to improve yield. An example of a reaction with a uranium hydride is the heating $\mathrm{UH}_{3}$ in contact with $\mathrm{NH}_{4} \mathrm{Cl}$ for 30 hours at $300^{\circ} \mathrm{C}$ to make $\left(\mathrm{NH}_{4}\right)_{2} \mathrm{UCl}_{6}$, which in turn will decompose to $\mathrm{UCl}_{4}$ at $350^{\circ} \mathrm{C} .{ }^{31}$ However, processes involving hydrides are thought to be too complicated to be feasible on a large scale, as they require the use of pyrophoric uranium metal.

Gas-phase reactions comprise two categories, gas-solid or gas-liquid, the latter of which produces a molten salt directly. Gas-phase processes tend to leave a residual oxide because of poor contact between the halogenating reagent and the solid phase. Reagents include the agents listed earlier, along with short chain organics such as $\mathrm{CHCl}_{3}$, as well as those with chlorine atoms bonded to a carbon atom alpha-to-adouble-bonded carbon atom, such as hexachloropropene. In addition to chlorine, inorganic reagents such as sulfur chlorides (e.g., $\mathrm{S}_{2} \mathrm{Cl}_{2}, \mathrm{SOCl}_{2}$ ) have also been investigated, as has been $\mathrm{CCl}_{4}$ that was generated from passing $\mathrm{Cl}_{2}$ over a hot carbon bed. The vapors of the chlorinating agents are highly toxic. A sweep gas, such as $\mathrm{CO}_{2}$, may be added to the chlorinating agent.

The best-known gas-phase process for producing $\mathrm{UCl}_{4}$ is through the carbochlorination, ${ }^{26}$ or reaction of $\mathrm{CCl}_{4}$, with uranium oxide. ${ }^{26}$ This process has been used on an industrial scale. It is carried out at 350 $450^{\circ} \mathrm{C}$, and both continuous and batch processes have been developed. Reaction temperatures and selected reducing agents are optimized to produce more $\mathrm{UCl}_{4}$ than $\mathrm{UCl}_{5}$. The pure and finely powdered uranium oxide reagent is made from the steam hydrolysis of $\mathrm{UF}_{6}$, a process that generates a large amount of $\mathrm{HF}$, which is a reaction product that is both toxic and corrosive. The reaction with $\mathrm{CCl}_{4}$ can produce 
phosgene as a product (as well as $\mathrm{CO}$ and $\mathrm{Cl}_{2}$ ), and an accident with carbochlorination caused a casualty at the Y-12 National Security Complex in Oak Ridge, Tennessee. ${ }^{32}$ Chlorine byproduct is soluble in unreacted $\mathrm{CCl}_{4}$, making this residual mixture both toxic and corrosive.

Liquid-phase reactions include those at atmospheric pressure, those using a reflux column, and those in vessels sealed to operate at temperatures above the normal boiling point, with pressures of 3-20 bar. The reflux method uses a reagent such as hexachloropropene at $100^{\circ} \mathrm{C}$, from which the reaction product can be precipitated and filtered. Heating the mixture to $165^{\circ} \mathrm{C}$ increases the yield of $\mathrm{UCl}_{4}$ over $\mathrm{UCl}_{5}$. Sulfur chlorides can also be used at atmospheric pressure and $138^{\circ} \mathrm{C}$ (the boiling point of $\mathrm{S}_{2} \mathrm{Cl}_{2}$ ), but they tend to leave a sulfur residue in the $\mathrm{UCl}_{4} \cdot \mathrm{UO}_{3}$ refluxed with $\mathrm{SOCl}_{2}$ at $78.8^{\circ} \mathrm{C}$ makes the adduct $\mathrm{UCl}_{5} \cdot \mathrm{SOCl}_{2}$ that decomposes at $300^{\circ} \mathrm{C}$ to make $98 \% \mathrm{UCl}_{4}$. The reflux method has also been investigated with organic chlorinating agents other than hexachloropropene, but the latter was the only one that showed success as the boiling points are generally too low for the chlorination reaction to proceed. A pressurized vessel has been used with $\mathrm{CCl}_{4}$ at temperatures from $140-160^{\circ} \mathrm{C}$ in two steps: (1) making $\mathrm{UCl}_{5}$ from $\mathrm{UO}_{3}$, and (2) decomposing the $\mathrm{UCl}_{5}$ to $\mathrm{UCl}_{4}$. However, the process is very sensitive to impurities, and it makes pressurized phosgene, which is a chemical hazard. Compounds similar to $\mathrm{CCl}_{4}$, such as $\mathrm{CBrCl}_{3}$ and $\mathrm{CBr}_{2} \mathrm{Cl}_{2}$, will also produce $\mathrm{UCl}_{4}$ directly in a bomb reactor at $130^{\circ} \mathrm{C}$.

Metathesis reactions (or halogen/oxide exchange) can also take place in a fusion medium, a refluxing column, or in a bomb reactor. These processes have been investigated with mixed results, and yields tend to be poor for most metal chlorides. However, molten $\mathrm{BeCl}_{2}$ (at $500^{\circ} \mathrm{C}$ ) was shown to completely convert $\mathrm{UO}_{2}$ to $\mathrm{UCl}_{4}$ in 4 hours. The conversion of the fluoride is more efficient than the oxide. For instance, $\mathrm{AlCl}_{3}$ at $225^{\circ} \mathrm{C}$ will convert $\mathrm{UF}_{4}$ to $\mathrm{UCl}_{4}$ more efficiently than $\mathrm{UO}_{2}$ to $\mathrm{UCl}_{4}$ (only $30 \%$ after heating at $200^{\circ} \mathrm{C}$ for 12 hours). The $\mathrm{UF}_{4}$ reaction with $\mathrm{BCl}_{3}$ and $\mathrm{AlCl}_{3}$ at $600-700^{\circ} \mathrm{C}$ will give $\mathrm{UCl}_{4}$.

$\mathrm{UCl}_{4}$ is very hygroscopic and will deliquesce to a liquid and fume at room temperature. When heated in air, $\mathrm{UCl}_{4}$ will produce $\mathrm{HCl}(\mathrm{g})$ and $\mathrm{U}_{3} \mathrm{O}_{8}(\mathrm{~s})$. $\mathrm{UCl}_{4}$ will react with fluorine to produce $\mathrm{UF}_{6}$, and it will react with $\mathrm{HF}$ to produce $\mathrm{UF}_{4}$. $\mathrm{UCl}_{4}$ will react with metal oxides to form $\mathrm{UO}_{2}$ and uranium oxychlorides.

Purification of $\mathrm{UCl}_{4}$ or $\mathrm{UCl}_{3}$ uses reagents similar to those used for the conversion reactions discussed above.

\subsubsection{Low Temperature Uranium Chloride Salt Production Through Organic Precursors}

Aqueous preparation of $\mathrm{UCl}_{4}$ is possible by forming an oxychloride or hydrated chloride intermediate and then decomposing the intermediate into $\mathrm{UCl}_{4}$ and $\mathrm{UO}_{2}$. The separation is by volatility, preferentially removing the $\mathrm{UCl}_{4}$ as a vapor species. $\mathrm{UCl}_{4}$ is not soluble in many organic solvents, and it decomposes when mixed with alcohols, ketones, esters, and carboxylic acids. Removal of the oxygenated organics listed above by heating will also volatilize $\mathrm{HCl}$ and leave a uranium oxychloride residue. Organics can be used to salt out uranium-bearing salts from aqueous solution. Enough chlorinated solvent is added to an aqueous uranium-containing solution to form an azeotrope; then the mixture is heated, first driving off the water, and then the solvent. If heated to $650^{\circ} \mathrm{C}, \mathrm{UCl}_{4}$ can be sublimed from the $\mathrm{UOCl}_{2}$ salt residue left behind by the organic solvent, leaving behind $\mathrm{UO}_{2}$. This process has not been optimized.

Direct reaction of $\mathrm{CCl}_{4}$ with $\mathrm{UF}_{6}$ is also possible. It is a two-step process to make $\mathrm{UCl}_{4}$ that first involves adding $\mathrm{UF}_{6}$ to a chlorinated solvent such as $\mathrm{CCl}_{4}$ to make $\mathrm{UF}_{4}$ in solution. The step to produce $\mathrm{UCl}_{4}$ is more difficult, but it likely goes through a mixed fluoro-chloro-uranium intermediate that decomposes, generating $\mathrm{UF}_{4}$ and $\mathrm{UCl}_{4}$. Use of $\mathrm{BCl}_{3}$ or $\mathrm{AlCl}_{3}$ as chlorinating agents assists the process. The product has low oxygen content, as there is no introduction of oxide or oxyhalide as starting materials, but it may contain some chlorine that must be distilled from the product. 
Use of organic complexes or stabilizing reagents have been explored on the laboratory scale, starting with acetyl acetonate, ammonium benzoate, and various acetate complexes. Tetrahydrofuran has been investigated as a complexing agent, but its synthesis requires $10^{\circ} \mathrm{C}$ and the addition of $\mathrm{HgI}_{2}$ to prevent unwanted byproducts. ${ }^{33}$ Similar syntheses have been done by reacting $\mathrm{UH}_{4}$ or uranium turnings in diethyl ether to give products at high yield, including $\mathrm{UI}_{3}, \mathrm{UI}_{4}\left(\mathrm{O}\left(\mathrm{C}_{2} \mathrm{H}_{5}\right)_{2}\right)_{2}$, and $\mathrm{UI}_{4}\left(\mathrm{O}\left(\mathrm{C}_{4} \mathrm{H}_{9}\right)_{2}\right)$. ${ }^{34}$ Uranium (III) and (IV) iodide complexes with dioxane have been prepared by reaction at room temperature over seven days with $95 \%$ yield. ${ }^{35}$ Low heat $\left(50^{\circ} \mathrm{C}\right)$ shortened the reaction time to less than a day. The resulting $\mathrm{UI}_{4}\left(1,4\right.$-dioxane) and $\mathrm{UI}_{3}(1,4$-dioxane) complexes can be converted by several uranium halides, including uranium (III) and uranium (IV) compounds. The dioxane complexes have already provided the building blocks for other uranium (III) compounds, as discussed in a recent report of the synthesis of pyridine complexes of $\mathrm{U}(\mathrm{III})$ compounds under mild conditions such as $\left[\mathrm{UCl}_{3}(\mathrm{py})_{4}\right]$ from the 1,4-dioxane suspension of $\left[\mathrm{UCl}_{4}\right]$ and magnesium turnings at $100^{\circ} \mathrm{C} .{ }^{36}$ These new synthetic methods have not been tested on a large scale, but if testing is successful, this should provide a safer approach than the standard approaches to uranium chloride chemistry that require high temperatures and hazardous reagents.

\subsubsection{Thorium Fluoride}

The fluorination of thoria can be carried out in the same manner as for urania, with exposure to fluorine or $\mathrm{HF}$. An alternative route that takes place at room temperature involves the mechanical contact between $\mathrm{ThO}_{2}$ and $\mathrm{NH}_{4} \mathrm{HF}_{2}$ to initiate the reaction between them. Products were observed after two hours, forming a fluorinated $[\mathrm{NH} 4]_{2} \mathrm{ThF}_{8} \cdot 2 \mathrm{H} 2 \mathrm{O} .{ }^{37}$ The process was sensitive to the presence of water, producing the oxyfluorides. Improvements to yield were achieved with heating the reagents to $250^{\circ} \mathrm{C}$ for 12 hours in a closed container, followed by heating the salt to $400^{\circ} \mathrm{C}$ for three hours to remove $\mathrm{NH}_{3}$ and $\mathrm{H}_{2} \mathrm{O}$. Purity was assessed by differential scanning calorimetry, showing a single peak at $1,110^{\circ} \mathrm{C} .{ }^{38}$

Safe handling of thorium fluorides and the materials used to prepare them will be similar to the measures used for preparation of uranium fluoride compounds.

\subsubsection{Transuranics from used LWR fuel}

There are a number of processes available to convert spent fuel, which is mostly $\mathrm{UO}_{2}$, into $\mathrm{UF}_{4} \cdot{ }^{39}$ First the spent fuel must be removed from the cladding and converted into a powder so that subsequent reactions will occur at a reasonable rate. The traditional method for reprocessing spent fuel uses a large shear to cut the fuel assemblies or the individual fuel pins (after removing the hardware) into small pieces and then leaching with nitric acid to dissolve the spent fuel. The uranium and plutonium can then be separated from the FPs, precipitated, and converted to oxides. The oxides can then be hydrofluorinated to produce fluoride salts for an MSR. An alternative to dissolving the spent fuel is voloxidation, a process in which the spent fuel pieces are heated with air, oxygen, or $\mathrm{NO}_{\mathrm{X}}$ to convert the $\mathrm{UO}_{2}$ to $\mathrm{U}_{3} \mathrm{O}_{8}$ or $\mathrm{UO}_{3}$. The conversion renders the higher oxides into powders that can be separated from the cladding pieces by sieving. The Zircaloy cladding can also be removed chemically by high-temperature chlorination (350$400^{\circ} \mathrm{C}$ ) using $\mathrm{HCl}$ or $\mathrm{Cl}_{2}$ and vaporizing the zirconium from Zircaloy as $\mathrm{ZrCl}_{4}$. The fuel could then be voloxidized to convert the pellets into powder, followed by hydrofluorination to produce $\mathrm{UF}_{4}$. Both the spent fuel and Zircaloy cladding can be converted into fluoride salts for use in an MSR. The details of the three processes for converting the spent fuel directly into fluoride salts are shown below. For all these processes, most of the actinides and FPs from the spent fuel would also be fluorinated and remain in the MSR fuel salt. Volatile FPs would end up in the off gas. 


\section{Chop-Voloxidize-Hydrofluorinate Process}

Figure 10 shows the proposed flow sheet for the $\mathrm{UO}_{2}$ to $\mathrm{UF}_{6}$ conversion process. The steps in this process are well developed and have been deployed in full-scale facilities in other countries. ${ }^{39}$ The Zircaloy cladding hulls from the spent fuel must be disposed of as high-level waste or be extensively cleaned for low-level waste disposal. The voloxidation step may use $\mathrm{NO}$ and $\mathrm{NO}_{2}$, which are both toxic, with PEL TWA for 8 hours of $25 \mathrm{ppm}$ and $0.2 \mathrm{ppm}$, respectively. Flammable hydrogen gas will be used in the chemical reduction step, and corrosive HF will be used in the hydrofluorination step. These two processes could be combined in one reactor.

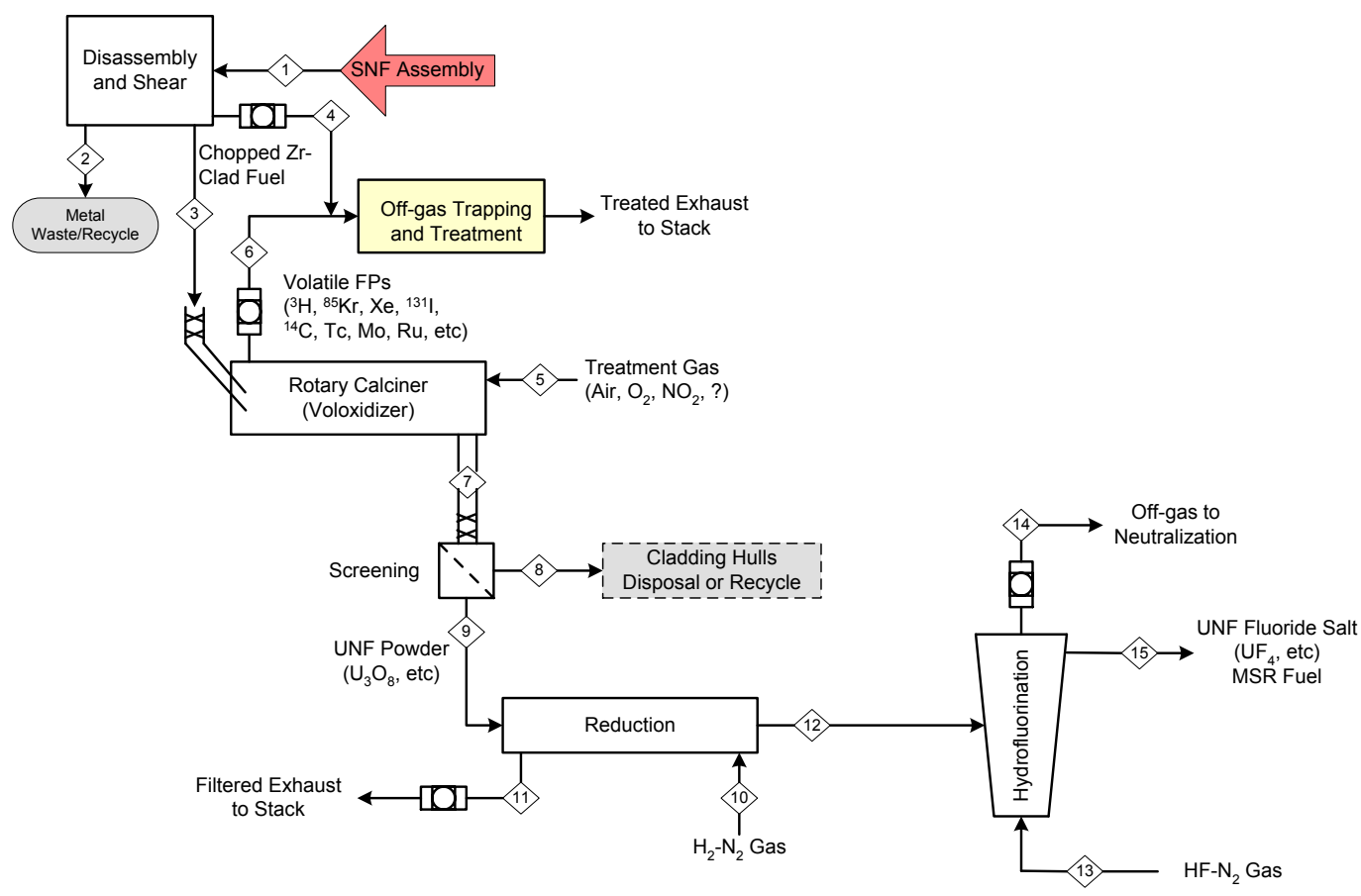

Figure 10. Schematic of the proposed chop-voloxidize-hydrofluorinate process flow sheet. ${ }^{39}$

A variation on this process, which is being evaluated by several MSR vendors, is to use a fluoride flame reactor to convert the uranium oxides produced by the voloxidizer into uranium fluorides. ${ }^{40,41}$ This process normally produces a $\mathrm{UF}_{6}$ stream that can be recovered separately from the nonvolatile actinide and FP fluorides. This process uses $\mathrm{F}_{2}$ gas, which is very corrosive and toxic, with a recommended PEL of $0.2 \mathrm{mg} / \mathrm{m}^{3}$.

Another potential variation is to use $\mathrm{NF}_{3}$ as the fluorinating agent rather than $\mathrm{HF}$. $\mathrm{NF}_{3}$ is much less corrosive and toxic than $\mathrm{F}_{2}$, but it is a strong fluorinating agent at higher temperatures. Thermodynamic calculations performed at Pacific Northwest National Laboratory (PNNL) show that the reaction between $\mathrm{NF}_{3}$ and $\mathrm{UO}_{2}$ to produce $\mathrm{UF}_{6}$ is favorable. ${ }^{42}$ This process is being evaluated for removing various oxides from MSR fuel but could possibly be used to produce the initial salt from spent fuel.

\section{Chemical Decladding-Voloxidize-Hydrofluorinate Process}

Starting with irradiated $\mathrm{UO}_{2}$, the Zircaloy cladding can be removed using chemical methods. It will react with anhydrous chlorine $\left(\mathrm{Cl}_{2}\right)$, anhydrous hydrogen chloride $(\mathrm{HCl})$ at $350-400^{\circ} \mathrm{C}$, or thionyl chloride at near room temperature to produce volatile $\mathrm{ZrCl}_{4} \cdot{ }^{39}$ The fuel remains intact and ready for the voloxidation and hydrofluorination. The decladding process is the main difference between the flow sheet shown in 
Figure 11 and the one shown previously in Figure 10. During the chemical decladding, tritium trapped in the cladding will be released into the off-gas system as ${ }^{3} \mathrm{HCl}$ (or TCl). Chlorine, $\mathrm{HCl} / \mathrm{TCl}$, and thionyl chloride are all toxic and corrosive, with PEL TWA limits of 1 ppm, 5 ppm and 2 ppm, respectively. Thionyl chloride decomposes above $140^{\circ} \mathrm{C}$, producing sulfur dioxide and hydrogen chloride, which are toxic and corrosive. It also reacts violently with water. The chemical hazards for the remaining steps would be the same as those used for the previous process.

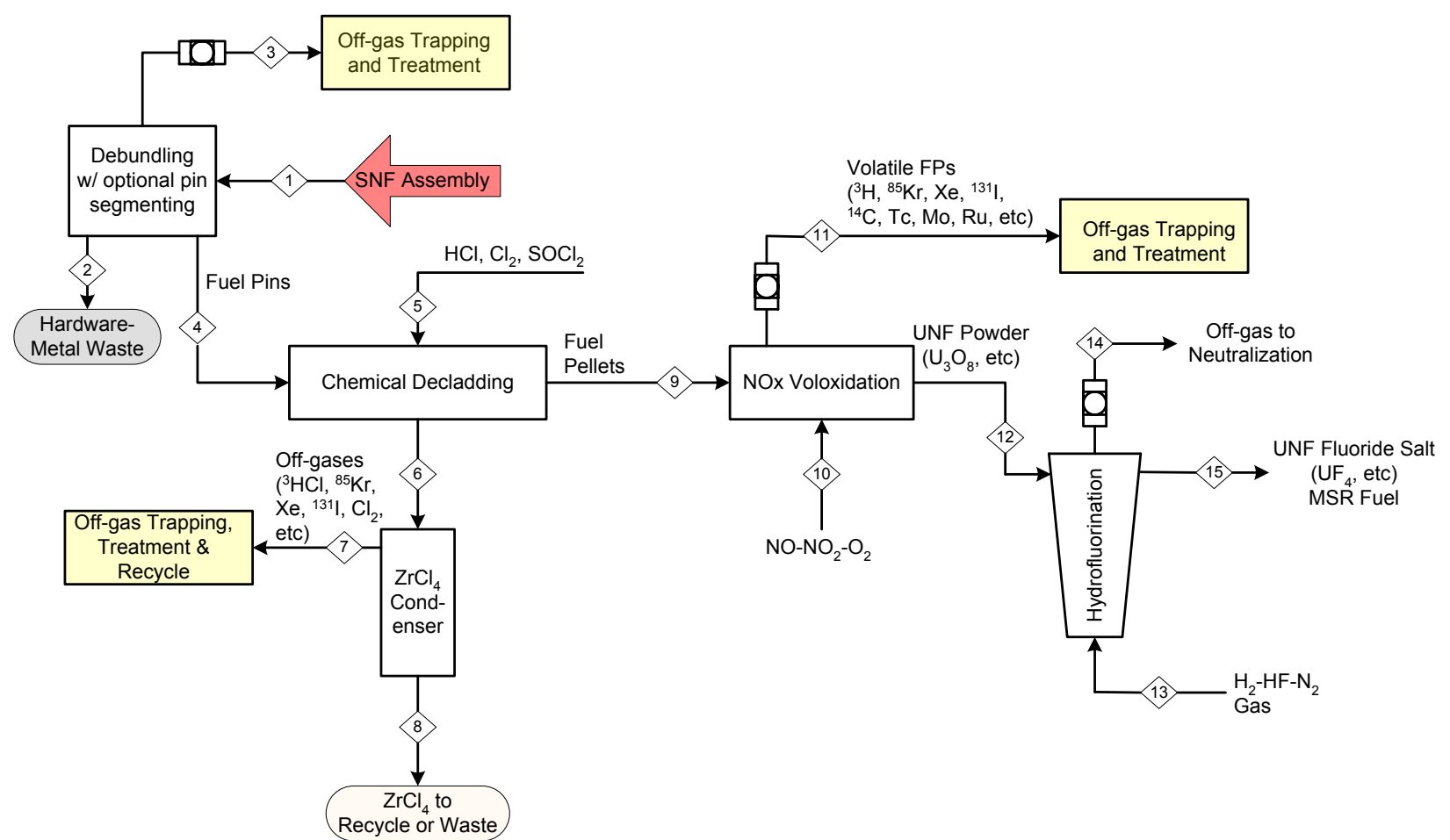

Figure 11. Schematic of the proposed chemical decladding-voloxidize-hydrofluorinate process flow sheet. ${ }^{39}$

\section{Dissolution of Fuel and Cladding in Molten Salt Process}

Spent $\mathrm{UO}_{2}$ fuel can be converted to fluoride salts by hydrofluorination in a molten salt. ${ }^{43}$ The zirconiumuranium-based fuel elements are dissolved in a molten fluoride salt at $600-700^{\circ} \mathrm{C}$, in which the oxides are converted to fluorides using anhydrous HF. To recover uranium from the spent fuel, the salt can be treated with with $\mathrm{F}_{2}$ to remove uranium as volatile $\mathrm{UF}_{6}$ in a fluorination process. Two fluoride molten salts were used in these experiments: $\mathrm{NaF}-\mathrm{ZrF}_{4}$ and $\mathrm{LiF}-\mathrm{NaF}$. At $600^{\circ} \mathrm{C}$, the $\mathrm{NaF}-\mathrm{ZrF}_{4}$ remained molten for compositions ranging from 40-60 to $60-40 \mathrm{~mol} \%$, and it could accommodate significant amounts of uranium. The $57-43 \mathrm{~mol} \% \mathrm{LiF}-\mathrm{NaF}$ has a liquidus temperature of $675^{\circ} \mathrm{C}$ and can dissolve zirconium up to a concentration of $55 \mathrm{~mol} \%$. Other salts may serve the same purpose, but this requires more testing.

A flow sheet was developed by Taylor et al. (2019), shown in Figure 12. This process flow diagram shows the removal of stainless-steel hardware and conversion of fuel pins to fluoride salts. ${ }^{39}$ Several variations of the process are possible, such as the development of a fuel pin cutting step to make lengths that are more easily handled. Some of these variations are listed below the figure and are taken from the same Taylor (2019) report. 


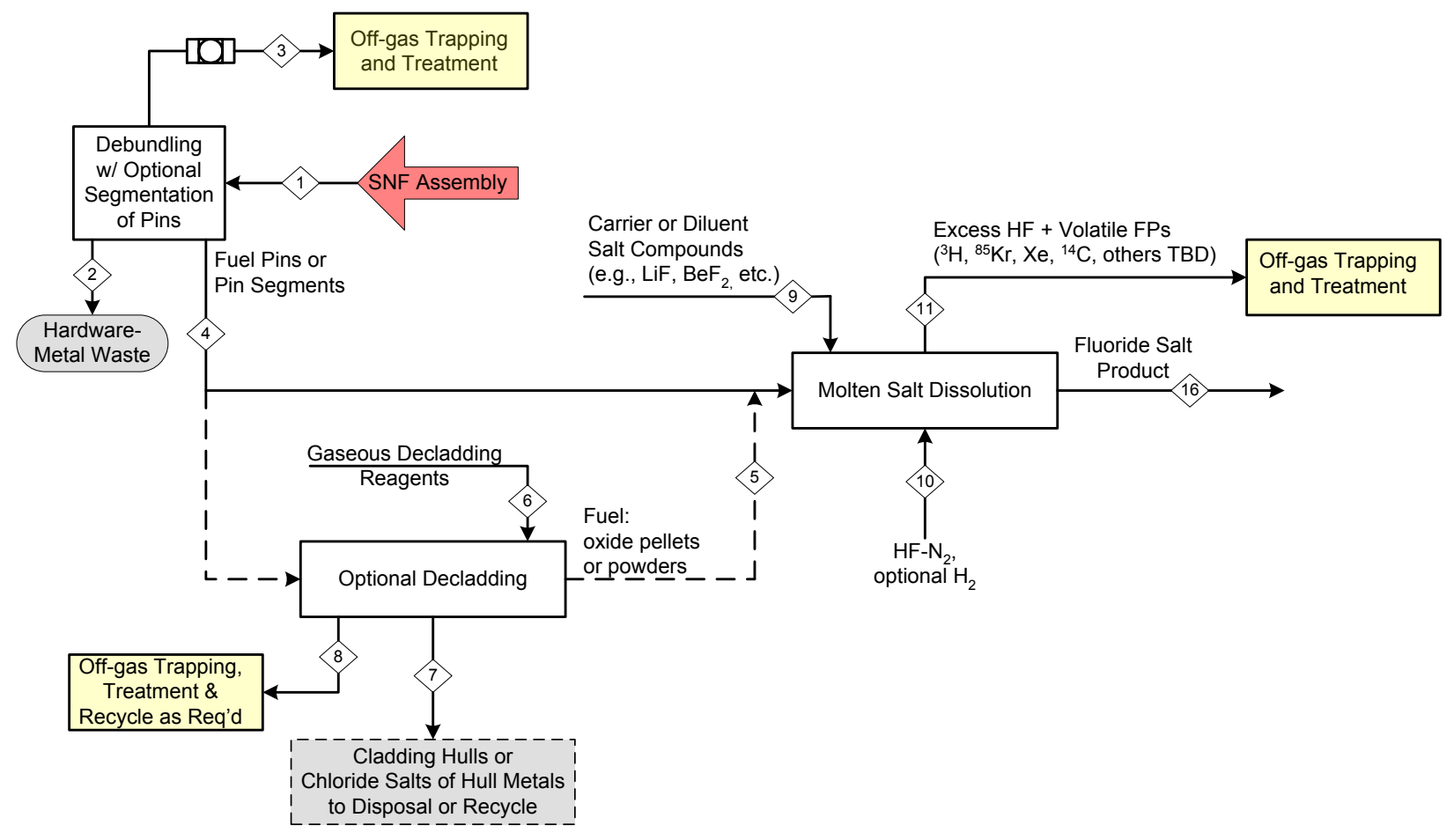

Figure 12. Concept for converting used fuel to fluoride salts by molten salt dissolution. ${ }^{39}$

1. The co-conversion of fuel and cladding is essentially the process shown in Figure 12. The first step removes the stainless-steel hardware after which the fuel pins can be segmented to reduce the scale of the molten salt bath used in processing. The Zircaloy-clad fuel is then converted to fluorides in a molten salt bath. Fluoride salts are added to make the proper ratio of carrier salt and used LWR fuel in the hydrofluorination flux, although it may be possible to use only the fluorides of the clad fuel $\left(\mathrm{UF}_{4}-\mathrm{ZrF}_{4}\right)$. Zircaloy generates a significant amount of hydrogen (and tritium) in the off-gas stream. Flammable hydrogen poses a risk that will require stringent engineering controls. The fluoride salt product will contain a higher concentration of $\mathrm{ZrF}_{4}$ than for the fuel salt used in MSRE. This process uses toxic and corrosive HF bubbled into a hot salt bath.

2. As discussed earlier, a chemical decladding step can be used to remove the zirconium, the primary constituent of the cladding before converting the fuel. The advantage of this process is that the declad $\mathrm{UO}_{2}$ fuel pellets can be converted to $\mathrm{UF}_{4}$ with $\mathrm{HF}$ without the concern of producing hydrogen. Because Zircaloy is not present, carrier salt must be added to provide a fluxing agent. Fission product oxides will be converted to fluorides. Tritium and volatile fission products released to the off-gas must be trapped for disposal. The hazards of this process would be the same as those associated with the chemical decladding process described above, along with the hazards for the HF and hot salt bath described in item 1 .

3. Decladding can also be done by voloxidation, following segmentation of fuel pins to improve the efficiency. The fuel is oxidized, and in air will convert $\mathrm{UO}_{2}$ to $\mathrm{U}_{3} \mathrm{O}_{8}$, and in $\mathrm{NO}_{\mathrm{X}}$, convert the $\mathrm{UO}_{2}$ to $\mathrm{UO}_{3}$. The higher oxides form powders that can be separated from the larger cladding pieces by sieving. Neither $\mathrm{U}_{3} \mathrm{O}_{8}$ nor $\mathrm{UO}_{3}$ is converted to $\mathrm{UF}_{4}$ with $\mathrm{HF}$; rather an oxyfluoride is produced. To achieve the production of $\mathrm{UF}_{4}$ from $\mathrm{U}_{3} \mathrm{O}_{8}$ or $\mathrm{UO}_{3}$, hydrofluorination using both $\mathrm{HF}$ and $\mathrm{H}_{2}$ is required. ${ }^{3}$ Tritium and other volatile fission products will have already been removed by the voloxidation process, so their release is not an issue in the subsequent hydrofluorination. Generated 
water vapor will not be contaminated with tritium. Because the voloxidized fuel is in powder form, the combination dissolution and hydrofluorination step will be rapid.

\subsection{SYNTHESIS OF MSR FUEL SALT}

The fuel salt for an MSR will be a combination of the fissile salt, usually $\mathrm{UF}_{4}$ or $\mathrm{UCl}_{3}$, with nonradioactive diluent or carrier salts, such as $\mathrm{LiF}, \mathrm{ZrF}_{4}, \mathrm{NaF}$, and $\mathrm{BeF}_{2}$ or $\mathrm{NaCl}, \mathrm{CaCl}_{2}$ and $\mathrm{MgCl}_{2}$. It is likely that the company producing the fuel salt will produce the fissile salt, purchase the non-radioactive salts from commercial sources, and then combine them to produce the fuel salt mixture. For the MSRE, all the fuel salt components were mixed at the reactor site, but this is considered unlikely for a power reactor. The fuel salt will likely be produced by an off-site company, as is done for the fuel assemblies used in an LWR, and then loaded in the reactor. Depending on the MSR design, the fuel salt may contain other components, such as fertile salts (U or Th) for breeder MSRs. Reuse of spent LWR fuel may mean that actinides and fission products are present in the fuel. These components would have little effect on the chemistry and chemical hazards of the fuel salt, but they will impose major radiation hazards. The salt production company providing the fuel salt will likely also be asked to supply small packages of salt containing much higher concentrations of the fissile material (refueling aliquots). These will be added to burner type MSRs during operation as needed to maintain reactivity.

\subsection{PACKAGING AND TRANSPORT OF ENRICHED UF 6 AND UF 4}

American National Standards Institute (ANSI) N14.1-2001 provides criteria for packaging uranium hexafluoride $\left(\mathrm{UF}_{6}\right)$ for transport. It includes specific information on design and fabrication requirements for the procurement of new $\mathrm{UF}_{6}$ packaging. This standard also defines the requirements for in-service inspections, cleanliness, and maintenance for packaging in service. The standard requires that $\mathrm{UF}_{6}$ enriched to greater than $1.0 \mathrm{wt} \%$ shall be packaged in accordance with the US Department of Regulations (DOT) regulations of Title 49 US Code of Federal Regulations (CFR) Parts 173 [5] and 178 [6] or in other NRC or DOE certified package designs. These packages consist of an inner $\mathrm{UF}_{6}$ cylinder (excluding Type $48 \mathrm{G}$ and $48 \mathrm{H}$, which are limited to $1.0 \mathrm{wt} \%$ assay or less) plus an outer protective package.

Packaging and shipment of enriched $\mathrm{UF}_{6}$ to be used for producing $\mathrm{UF}_{4}$ for molten salt reactors is no different than packaging and shipment of $\mathrm{UF}_{6}$ to be used for producing $\mathrm{UO}_{2}$ reactor fuel, so there are no new hazards. $\mathrm{UF}_{4}$ is hygroscopic and forms $\mathrm{UF}_{4} \cdot 0.75 \mathrm{H}_{2} \mathrm{O}$, albeit slowly.

$\mathrm{UF}_{4}$ has similar transportation hazards to those for $\mathrm{UO}_{2}$, except that $\mathrm{UF}_{4}$ can have a very slow reaction with water to produce uranyl fluoride $\left(\mathrm{UO}_{2} \mathrm{~F}_{2}\right)$ and $\mathrm{HF}$. Criticality concerns would be the same, and the packaging requirements should be the same or very similar. The packaging for $\mathrm{UF}_{4}$ may need to be rated for an underlying hazard of corrosivity, which is not the case for $\mathrm{UO}_{2} . \mathrm{UF}_{4}$ and fuel salt mixtures that will be used in an MSR must be kept free of moisture and oxygen contamination, which greatly increases the corrosivity of the mixture. The packaging must be designed to exclude moisture, and the fuel salt must be loaded under inert conditions. The packaging must also be designed to prevent criticality during transportation and storage.

\section{REACTOR SITE FUEL PROCESSES AND HAZARDS}

This section describes processes and operations to maintain the fuel salt within its required specifications. Chemical aspects of reactor operation are described, as well as nuclear operations and the operations of various support systems and functions necessary for the reactor to operate efficiently and safely within its design and regulatory specifications. 


\subsection{LIQUID-SALT OPERATIONS}

An MSR operates as a chemical reactor as well as a nuclear reactor. During burnup, the FPs will accumulate in the fuel salt and will circulate throughout the core. Many of the salts' physical behaviors will depend on temperature gradients and chemical environment, the latter being governed by the chemical potentials of fuel salt components. Fission will gradually produce a more oxidizing environment. If a fluoride-based salt is being used, then activation and decay will produce oxygen and nitrogen. These processes, particularly fission, will change the redox state of the salt, in some cases changing the chemical form of FPs and the ratio of uranium redox species. The composition of the salt will affect the corrosion rates of reactor materials, the volatility of some chemical species, and the precipitation and plating of others on the internal surfaces of the reactor.

MSRs operate at high temperatures, well above the melting point of the salt $\left(<550^{\circ} \mathrm{C}\right)$. Normal operating conditions are typically $650^{\circ} \mathrm{C}$ or higher. Off-normal events may have temperatures exceeding $800^{\circ} \mathrm{C}$.

Salts have relatively low viscosities, and some salts wet metal surfaces, tending to creep up vessel walls and making them difficult to contain. Reactor materials need to be able to maintain structural integrity at high temperatures. Molten salt mechanical joints frequently leak, primarily due to creep of the bolts providing the sealing force. Diffusion of tritium and helium through metals is increased at high temperatures. On the other hand, elevated temperatures mean that chemical processes occur quickly and are not limited by chemical kinetics but can be described using chemical thermodynamics. At operating temperature, recombination within the salt dominates radiolytic damage production. Finally, high temperatures mean that physical property data used to describe salt thermal property data and transport are difficult to collect and have substantial uncertainty.

MSRs operate at pressures just above ambient, as the vapor pressures of the salts are very low under normal operation. A breech in the reactor vessel means that the salt will ooze through a crack and solidify rather than experiencing a pressurized mechanical break-up into a spray of aerosolized particles and gases such as in an LWR severe accident. Molten salts are hygroscopic and are readily contaminated by air exposure, but they do not have any energetic chemical reactions with air or water. Consequently, it is useful to employ an inert containment environment to minimize the potential for contamination during any maintenance activities in which the salt boundary is broken. The containment floor will almost certainly be made of stainless steel to prevent hot salt from directly interacting with concrete in the event of a severe accident.

Moving fissile material through a heat transfer loop results in additional safety issues. Any inhomogeneities in the concentration of the fissile material will lead to variations in reactivity. As some fuels melt incongruently and some fuel salts operate near fissile material solubility limits, over cooling accidents may result in solidifying fissile materials at the coldest part of the heat transfer loop. The actinide trifluorides have limited solubility and at low temperatures, their joint solubility is much less than their individual solubilities. ${ }^{44,45,46}$ Off-line fuel handling or recovery of actinides will pose similar concerns about inadvertent criticality. Also, salt vapors, mists, and aerosols released at the fuel's surface will plate out on the walls of the cover-gas system.

Undissolved (noble) FPs will plate out onto surfaces. The largest surface is the heat exchanger. These highly radioactive materials will likely constitute the largest potential dose to personnel during maintenance/replacement activities and may result in long-term fouling of the heat exchange surfaces.

\subsection{FUEL LOADING}

The process for loading fuel into the salt reactor is distinctly different from that of solid fuel reactors. For example, solid fuel reactors cannot be overfilled. On the other hand, solid fuel reactors must have 
sufficient excess reactivity available to maintain criticality until their next refueling interval. MSRs will only have the reactivity necessary for current operation and will be nearly continuously refueled (or defueled in the case of breeders), making inadvertent criticality less likely. Fuel salt will arrive at the reactor site in a solid form in standardized containers. The salt will be melted prior to being introduced into the fuel salt circuit. The multiple containers of fuel salt will likely be combined into a salt maintenance/storage vessel within containment near the reactor vessel. From there, the fuel salt will be hydraulically transferred into the fuel salt circuit.

An alternative method for initial fueling of an MSR (apart from the concentrate salt addition method discussed in Section 2.2) would be to externally heat the core materials and the fuel salt to above operating temperature, after which the fuel salt would be introduced into the core. This process would avoid criticality during fueling because of the strong negative reactivity temperature feedback.

Refueling systems for future MSRs have not yet undergone final design, or if designed, then not publicly disclosed. Consequently, descriptions of specific mechanisms or hazards is not yet possible. However, the general requirements for introducing to and/or removing fuel salt from an MSR limit the potential methods and mechanisms for refueling. Refueling will likely be performed by adding and/or removing premeasured aliquots of fuel salt into the fuel salt circuit at the time intervals required to compensate for burning/breeding. (Metering liquid fuel salt is much more complicated than changing the interval at which premeasured quantities of fuel salt are added.) Uniform individual fuel salt portions will likely be prepared at the fuel salt facility and melted or dissolved into the fuel salt circuit as needed to maintain criticality. For example, if the plant is operating at $100 \%$ power, then a fuel aliquot may be added every shift, but if the plant is operating at reduced power, then fuel addition would occur less frequently. Planned reductant addition methods to compensate for fuel salt oxidation due to fission have not yet been selected. The refueling salt may be in a reducing state, or a separate reductant (likely Be or $\mathrm{Mg}$ ) will be added to the fuel salt circuit. A recent review lists several means to achieve redox control: gas sparging, adding a reductant, and using redox buffers. ${ }^{47}$ The plant will likely receive a significant quantity (months) of fuel portions so as to minimize the frequency of fuel shipping and the requirement to break containment to introduce additional material. Remote systems would be employed to select an individual aliquot and transfer it into the fuel salt circuit.

At the MSRE, the same system was used for sampling and for enrichment through the gas-locked system, as discussed in the section on online sampling and shown in the schematic below. ${ }^{48}$ The enriching capsule was capable of adding $90 \mathrm{~g}$ of ${ }^{235} \mathrm{U}$ to the reactor. Because the primary and secondary containment barriers had to be breached to add the fuel, the system was set up so that two barriers were always present between the core and the atmosphere, as well as between the sample and the atmosphere. Pressurization was used to determine if the penetrations in the barriers were closed at the required times to maintain an inert gas buffer. The enriching capsule was made of nickel tubing and was drilled with holes to allow the salt to escape. Operational details are given by Gallaher and in the summary report compiled by Guymon. ${ }^{49}$ The device was functional, but modifications were made in response to problems encountered during operation. One modification allowed for the use of magnetic alloys for the keys and capsules. This allowed the keys and capsules to be retrieved or manipulated if they came out of alignment. Repair of the drive unit required shut down and draining of the reactor. However, the enrichment-sampler was deemed a success and was operational at the end of the MSRE project. 


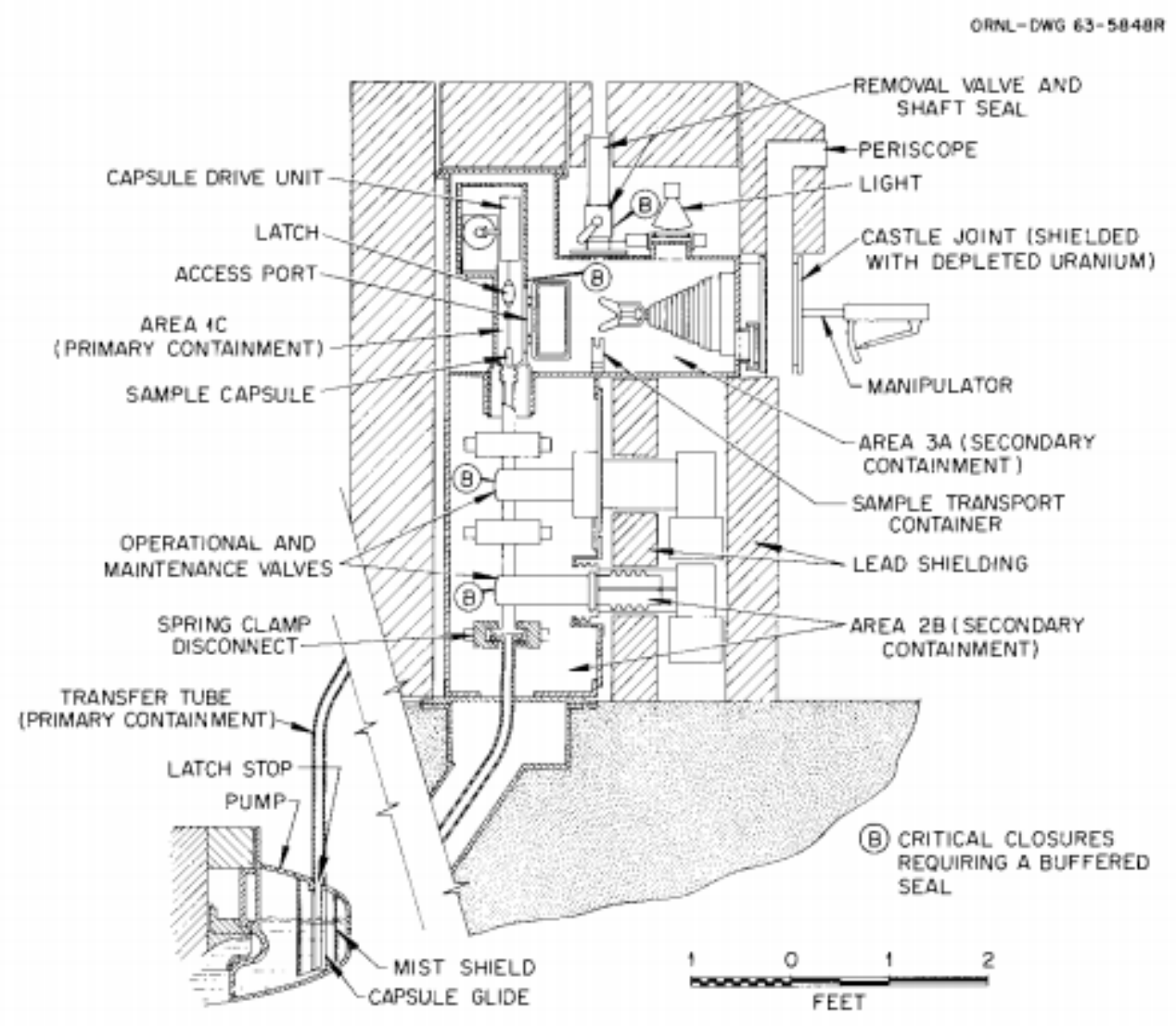

Figure 13. MSRE sampler-enricher. ${ }^{46}$

\subsection{FUEL SAMPLING}

MSR operators will periodically need to sample the fuel salt. MSRE surveillance sampling methods were reviewed in the ORNL progress report compiled by Briggs. ${ }^{50}$ These samples included specimens immersed in the salt: graphite, Hastelloy-N tensile bars, and wires for monitoring the flux. Salt samples were also extracted from the reactor for analysis in nearby facilities. A sampler-enricher was developed for adding material and taking salt from MSRE. ${ }^{48}$ The sampling vessel was inserted into the pump surge tank, and molten salt was collected in a scoop. The vessel was introduced into the core through an antechamber that was evacuated or purged to prevent air from contacting the salt during introduction of the vessel. A carousel was used so that multiple samples could be taken during a cycle.

\subsection{OFF-GAS SYSTEM}

Fission gases and aerosols will be released from the fuel salt into the cover gas. The location of the free surface within the fuel salt loop will depend on the reactor design. While the MSRE included its free surface within the pump bowl, a free surface could instead be provided in a dedicated component located at the high point of the fuel salt loop. As the released materials are highly radioactive, the fuel salt cover gas system is part of first layer of radionuclide containment.

The radionuclides transported with the cover gas will release substantial thermal energy, resulting in a need to provide decay heat removal for the cover gas system. Roughly $40 \%$ of FPs transition through a gaseous element in their decay chains. The amount of thermal loading in the cover gas system will depend 
strongly on the degree to which the short-lived fission gases evolve from the salt. If the short-lived FPs are retained in the fuel salt, then their decay heat will contribute to the fuel salt's thermal load. However, if the short-lived FPs transport with the cover gas, then the cover gas system will have a much higher thermal load. Whether fission gases should be aggressively stripped from the fuel salt is a design choice, so no general conclusions can yet be reached about the cover gas thermal performance requirements.

A general summary of the technologies for an MSR off-gas system was recently developed by Riley and colleagues, ${ }^{51}$ much of it based on MSRE operational experience. ${ }^{52}$ The paper specifies the species that are expected to be found in the headspace of an MSR, including salt aerosols, noble gases, reactive gases, tritium, volatile and semi-volatile halides, and activation products. These species will be swept through a set of traps for decay and storage using a helium sparging gas. Various methods for trapping and immobilizing the gaseous species were described as follows:

1. Molten hydroxide scrubber for particulates, aerosols, reactive gases, and halides

2. Immobilized zeolite for capture of tritium (and hydrogen), which can be recombined to form $\mathrm{HTO}$ (and $\mathrm{H}_{2} \mathrm{O}$ ).

3. Silver-functionalized packed beds to capture residual iodine and other halides

4. Cryogenic capture and release of non-radioactive gases such as $\mathrm{N}_{2}$ and $\mathrm{O}_{2}$ generated by radiolysis

5. Capture and separation of noble gas FPs through cryogenic distillation, activated carbon, metalorganic frameworks

Some of these systems were tested at MSRE, and others were tested at the laboratory scale. Implementation of an off-gas system has been considered for reactor operations and for associated fuel processing. Some examples are given in the discussion below.

In MSRE, a flow of helium through the fuel pump bowl was used to flush FPs to activated charcoal beds. ${ }^{53}$ Helium was also used to move salt from one tank to another, and the gas was also passed through the charcoal beds. The helium was treated by passing it through a hot titanium sponge with specifications set at $<1 \mathrm{ppm}_{2}$ and $<6 \mathrm{ppm} \mathrm{H}_{2} \mathrm{O}$. However, the pressure in the cover gas system was difficult to control because of the deposition of solids and tar in the off-gas throttling valve and filter. ${ }^{54}$ The solids were derived from the coolant salt and from Hastelloy-N mixed with oil that had seeped into the system down the shafts of the fuel pump and coolant pump (including ${ }^{89} \mathrm{Sr},{ }^{140} \mathrm{Ba},{ }^{140} \mathrm{La},{ }^{103} \mathrm{Ru},{ }^{132} \mathrm{Te}$, and ${ }^{137} \mathrm{Cs}$ as measured by gamma spectrometry). Spectrochemistry showed lithium, beryllium, and zirconium. A filter deliberately placed to remove solids in the off-gas mainly trapped solid daughters of noble gas FPs. However, other FPs also form solids during operation and can be swept from the salt. These include tellurium, molybdenum, ruthenium, niobium, and antimony. Niobium can build up after reactor shutdown, as it is the daughter of ${ }^{95} \mathrm{Zr} .{ }^{239} \mathrm{Pu}$ is not volatile and remained in the salt.

The stripping efficiency of the helium flow from the pump bowl and graphite was tested by the injection of ${ }^{85} \mathrm{Kr}$. The void fraction in the salt was $0.6 \% .{ }^{55}$ The authors recommended chemical surveillance of the reactor during operation for (1) oxide contaminants in the fuel salt, (2) corrosion, (3) oils and hydrocarbons, and (4) isotopic composition of uranium and plutonium through grab samples. ${ }^{56}$ Areas that need to be sampled are the gas phase above the fuel salt, the salt itself (to ascertain its oxide content and its redox potential), and the outflow of online processing streams (to check for species such as bismuth).

The off-gas system for a molten salt breeder reactor design was described by Kasten. ${ }^{57}$ In the MSBR, both the fissile and fertile streams were to be recycled, with Pa removal by liquid bismuth from the fertile loop. Uranium was to be cycled online over 30 days as volatile $\mathrm{UF}_{6}$. A slip stream of the $\mathrm{UF}_{6}$ would pass through a scrubber to remove volatile FPs and then would be recycled to the reactor. The volatilization of the $\mathrm{UF}_{6}$ and the diluent $\mathrm{LiF} / \mathrm{BeF}_{2}$ at $500^{\circ} \mathrm{C}$ would leave behind a slag of rare earths. Reduction of the $\mathrm{UF}_{6}$ to $\mathrm{UF}_{4}$ with hydrogen reduces and precipitates metals $(\mathrm{Cr}, \mathrm{Fe}$, and $\mathrm{Ni}$ ) that would be filtered and sent to 
waste. The off-gas system would serve both the reactor and the processing plant and would include a $\mathrm{NaF}-\mathrm{MgF}_{2}$ sorber operating at $100-400^{\circ} \mathrm{C}$, as well as a cold trap operating at $70^{\circ} \mathrm{C}$. The reactor was designed so that the residence time of entrained fission gases was less than one minute. The gases would be removed by sparging the salt with an inert gas. Key safety features included continuous cooling of the processing equipment and concerns about criticality. Xenon and krypton would be stripped from the fuel salt by sparging with an inert gas such as helium. The processing of $U_{F}$ by volatility included the use of hydrogen and fluorine, gases that must be kept separate. In the off-gas flowsheet, fission product gases would be allowed to decay and then would be passed through water-cooled charcoal beds that retain ${ }^{135} \mathrm{Xe}$ for 48 hours. ${ }^{85} \mathrm{Kr}$ would be captured on a molecular sieve and cooled by liquid nitrogen, and then it could be transferred into a tank for storage, regenerating the sieves. The purge gas would be filtered, compressed to $40 \mathrm{psia}$, and returned to the reactor, or alternatively, vented. Design details were lacking in two important respects. One area where design details are lacking is in the effective capture of tritium, which needs more study, as has been reiterated in a review of the MSRE experience. ${ }^{48}$ The second area of concern is that aerosol capture must be achieved using cold traps or filtering, and these separations must also be able to remove contamination from organics coming from the lubrication of pump machinery.

Fluorine volatility was used to recover uranium in MSRE. ${ }^{58}$ In the MSRE fuel processing facility, the fuel $\left(<30^{\circ} \mathrm{C}\right.$ above the liquidus) was collected in a storage tank and exposed to fluorine in helium. The off-gas included $\mathrm{UF}_{6}$, excess fluorine, helium, $\mathrm{MoF}_{6}$ ( $\mathrm{FP}$ and resulting from corrosion), $\mathrm{CrF}_{4}$ and $\mathrm{CrF}_{5}$ from corrosion of the tank, $\mathrm{IF}_{7}$, and the fluorides of tellurium, niobium, ruthenium, and antimony. The gas then passed through a $\mathrm{NaF}$ trap kept at $400^{\circ} \mathrm{C}$ that retained most of the FPs, including $\mathrm{NbF}_{5}$. The gas that now included $\mathrm{UF}_{6}$, fluorine, helium, $\mathrm{MoF}_{6}, \mathrm{IF}_{7}, \mathrm{TeF}_{6}$ and traces of the other FPs then was passed through a series of $\mathrm{NaF}$ absorbers heated from $90-120^{\circ} \mathrm{C}$ to retain the $\mathrm{UF}_{6}$ but not the other gases. In MSRE, the off-gas without uranium was sent through a molten hydroxide $(2 \mathrm{M} \mathrm{KOH} / \mathrm{KI})$ scrubber to capture the fluorine and residual FP fluorides. The caustic scrubber captured the iodine, but this method was not as effective at eliminating tellurium from the gas flow. A final series of filters and traps polished the gas before venting it through the stack, including alumina to remove volatile tellurium hexafluoride. A flame arrester was included because of the generation of oxygen ( $25 \%$ of the fluorine) in the molten salt scrubber.

In future designs, the unreacted fluorine can be recycled through a surge chamber by a positive displacement pump. Kasten proposed a $\mathrm{NaOH}-\mathrm{KOH}$ scrubber ${ }^{59}$ operating as a continuous countercurrent packed bed. A slip stream of the hydroxide could be sent to waste, enabling online replenishment. The scrubber's off-gas could be contacted with steam to hydrolyze FPs such as tellurium, the oxides and hydroxides could then be filtered. The processing off-gas and the reactor off-gas could undergo similar final treatment steps if they co-located in the same facility. Handling of hydroxide mixtures has been considered, along with their use as media for thermal energy storage. ${ }^{60,61}$

Proper handling of the off-gas system will be important to reactor operation and site safety. Configuration of the off-gas system to confine fission gases and trap particulates means that it will be operating continuously and also that on-line maintenance will be required. Maintenance will have to be performed with remote handling because of the quantity of radioactive elements. In some cases, such as if a hydroxide scrubber is used, there will be a chemical hazard, but this is being used in other industries, and similar safety protocols can be used. Replaceable components of the off-gas system such as filter beds or hydroxide salt will need to be contained on site in the same manner as for used fuel before preparation for permanent disposal. ${ }^{85} \mathrm{Kr}$ may be separated and sold as a byproduct of operation. ${ }^{62}$ The greatest technical challenge for reactor developers will be in assessing off-gas performance during reactor operation. Gamma spectroscopy is used for current reactor designs, but the background in an MSR off-gas may reduce the effectiveness of gamma analysis. Online sampling methods for FP compounds such as the use of optical spectroscopy are being considered. Laser-induced breakdown spectroscopy and laser-induced 
fluorescence analyses have been shown to be effective in determining metals loading in industrial environments such as flue gas emissions. ${ }^{63}$

\subsection{INSOLUBLE FISSION PRODUCT FILTERING}

Some of the FPs produced in the MSR will be insoluble in the molten salt, so they will require filtration for removal. The filter is likely to be made from porous metal such as Hastelloy and will likely be placed in a recirculating side stream from the reactor core. The filter will require periodic changing, which will involve pulling the filter out of the salt, allowing any remaining salt inside the filter to drain, installing a new filter, and then packaging the old filter for disposal. The dose rate on the old filter will be very high due to the insoluble FPs and any residual fuel salt remaining on the filter. All these operations must be performed without allowing significant amounts of moist air to contact the molten salt. Prior to changing the filter, the recirculating salt flow should be turned off, and it may be possible to drain the salt from the recirculation loop. The historic MSR program provides basic information on the design and performance of large molten salt mechanical filters. ${ }^{64}$ Design of the filter, the filter holder, and the filter removal equipment for commercial-scale MSRs to allow for remote removal and replacement remains a significant challenge.

\subsection{SOLUBLE FISSION PRODUCT SEPARATION}

\subsubsection{Chlorides}

Burn-up produces a myriad of elements in molten salts, but electrorefining provides a method to selectively separate metals. This method has mostly been studied in the context of pyroprocessing in chloride salts. ${ }^{65}$ In pryoprocessing, the actinides are removed at the cathode, leaving FPs such as rare earths in the melt. The volatile FPs (e.g., Cs, I, and the noble gases) are removed during the head-end processing. To increase the solubility of metallic FPs by converting them into chlorides, an oxidizing agent such as $\mathrm{UCl}_{3}$ can be added to a chloride melt if it is not already present, with the uranium being

plated out as the metal. ${ }^{66}$ Besides the hazards already noted when using chloride and fluoride salts - such as elevated temperatures and corrosivity-electrorefining processes are likely to have fewer chemical hazards than salt preparation, such as those processes discussed in Section 3. This is because the salts are already in the halide form. However, the radiolytic hazards will be considerable due to working with spent fuel. Therefore, operations must be performed remotely, and the collected materials must be stored appropriately for recycling (in the case of the carrier salts) or waste disposal (FPs).

\subsubsection{Fluorides}

There has not been much electrorefining work performed on fluoride salts in the context of nuclear fuel remediation; however, the aluminum industry has been achieving separations in fluoride salts since the $1880 \mathrm{~s} .{ }^{67}$ For a fluoride salt in which many of the metals $(\mathrm{M})$ are in the form of $\mathrm{MF}_{3}$, contact with a reducing agent - a soluble metal solvent such as aluminum or an aluminum-copper alloy-allows precipitation of the metal on the cathode. A liquid metal such as bismuth has also been used as an electrode in fluoride salt separations ${ }^{68}$ or as an immiscible extractant phase in a centrifugal contactor. ${ }^{69}$ Aluminum has also been considered for use in separating lanthanides from actinides. ${ }^{70}$ In the case of used nuclear fuel, once the actinide has been removed, the other metals such as the rare earths can be separated from the salt. This has been demonstrated using the hydrofluorination of oxide fuel by the French Commissariat à l'Energie Atomique (CEA). ${ }^{71}$ More recently, an electrochemical cell was used to separate samarium and gadolinium in $\mathrm{LiF}-\mathrm{BeF}_{2}$ by plating the metals onto insoluble electrodes: molybdenum and nickel, respectively. ${ }^{72}$ Glassy carbon served to contain the melt and also acted as a counter electrode. Platinum was used as the pseudo-reference electrode. However, this method of separation requires research before it can be used for an MSR. For instance, the Czech study found that gadolinium formed 
an alloy with nickel that may also have contained some beryllium. The small electrochemical window of the $\mathrm{LiF}-\mathrm{BeF}_{2}$ melt meant that the samarium reduction was limited to one electron: $\mathrm{Sm}^{3+}$ to $\mathrm{Sm}^{2+}$. However, the relative simplicity of working with molten material under argon and generating solidified products leaves reductive extraction as one of the safer separation methods that can be carried out to remove FPs from the salt.

\subsubsection{Vacuum Distillation}

Tests were conducted at ORNL to assess the relative volatility of FPs in $\mathrm{LiF}_{-} \mathrm{BeF}_{2}{ }^{73}$, the removal of LiF$\mathrm{BeF}_{2}-\mathrm{ZrF}_{4}$ from MSRE salt. ${ }^{74}$, and recovery of unburned fuel ${ }^{233} \mathrm{UF}_{4}, \mathrm{LiF}_{-} \mathrm{BeF}_{2}$, and $\mathrm{LiF}_{-} \mathrm{ThF}_{4}$ in the MSBR. ${ }^{75}$ Results from these experiments were used to inform the design of the waste handling system of the MSBR. ${ }^{76}$ Vacuum distillation achieves better separation at lower temperatures.

The apparatus had four components, all made of Hastelloy-N: (1) a feed tank, (2) an annular still, (3) a condenser, and (4) a holding vessel. The apparatus was certified to handle external pressures of $1 \mathrm{~atm}$ at temperatures ranging from $600^{\circ} \mathrm{C}$ (for the feed tank) to close to $1,000^{\circ} \mathrm{C}$ (the still). The apparatus was mounted above a catchment vessel in case of leaks. An Inconel filter was used upstream to remove metal particles from the salt before it entered the apparatus. A filter was also placed in the line to the vacuum pump. Valves and piping that did not contact the salt were made of stainless steel. Instrumentation included conductivity probes to measure salt levels, pressure taps, ionization chamber radiation monitors on the filters and liquid nitrogen trap, and Geiger counters on the pumps. Discrete sampling during the process involved filling a vessel with $10 \mathrm{~g}$ of condensed salt. The vessels were manipulated in the vertical direction by a sampling tool and in the horizontal plane with a turntable. The sampling chamber was alternatively purged with argon or evacuated to minimize contamination of the distillation process with air.

An experiment with irradiated MSRE salt followed commissioning tests with pure salt and simulants. The isotopes that were followed included ${ }^{95} \mathrm{Zr},{ }^{144} \mathrm{Ce},{ }^{147} \mathrm{Pm},{ }^{155} \mathrm{Eu},{ }^{91} \mathrm{Y},{ }^{90} \mathrm{Sr}$, and ${ }^{137} \mathrm{Cs}$. The relative volatilities of the rare earths were higher than expected at 0.01 to 0.001 . However, the concentrations in the distilled salt were reduced to about $3 \%$ of the initial values, and $95 \%$ of the ${ }^{7} \mathrm{Li}$ was recovered.

Chemical hazards from vacuum distillation are likely lower than in other methods. However, pressure and vacuum envelopes must be manipulated and maintained to achieve the desired separations. Processing of slag from the distillation, filters, and other equipment must be performed remotely, as these will be highly radioactive. Online sampling to assess performance would also be desirable, as the tests with MSRE salt showed that experimentally determined volatilities were different from calculated values, as they were higher for lanthanides and lower for ${ }^{137} \mathrm{Cs}$ than expected.

A variation on vacuum distillation includes a prior reaction to the distillation step. This was tested on a chloride mixture, LiCl-KCl-rare earth chlorides. ${ }^{77}$ The salt was reacted with a mixture of lithium and potassium phosphates that immobilized the rare earth chlorides as phosphates in the mixture, facilitating the separation of the carrier $\mathrm{LiCl}-\mathrm{KCl}$ salt.

\subsubsection{Oxidative Precipitation}

Removal of rare earths from $\mathrm{LiCl}-\mathrm{KCl}$ salt can be achieved by using oxidative precipitation. This has been demonstrated at bench scale by sparging with oxygen at $750^{\circ} \mathrm{C}$ for several hours. Rare earths are precipitated as the oxides or oxychlorides. ${ }^{78}$ Introduction of pure oxygen into the chemical reactor will require precautions to minimize the possibility of combustion or explosion. However, once volatiles have been removed during the head-end process, the precipitate should be ready for waste disposal in the appropriate container. 


\subsubsection{Melt Crystallization}

Purification through freeze-thaw cycles is a well-known method for purifying substances. Melt crystallization was demonstrated at the bench scale to remove $\mathrm{LiCl}$ from simulated $\mathrm{FPs}$, namely $\mathrm{CsCl}$ and $\mathrm{SrCl}_{2}$, which have lower melting points. ${ }^{79}$ Using this method, $\mathrm{LiCl}$ frozen onto a cold finger might be separated from the bulk of FPs. Salt transfer and handling may be more complicated than in the previously discussed examples of using gaseous or liquid separations, but the possibility of having a release of material from the vessel is likely lower when using this process.

\subsection{WASTE FORM PREPARATION}

Wastes from an MSR will include those generated during salt preparation or purification prior to irradiation; those generated during operation such as through sampling, analysis, online processing, filter change-out, or off-gas management; those generated at the end of a fueling cycle; and those generated at the end of reactor operation. Many of the radiological hazards will be similar to those for operation of other nuclear power plants, so these will not be discussed in detail. The unique aspects of MSR wastes relate to the chemistry of the salt and the possible needs for actinide recovery and preparation of stable waste forms.

\subsubsection{Actinide recovery}

Salt separation processes can be used to remove the volatile FPs and recover carrier salts. Actinides can also be recovered either for reuse in a reactor or for segregated disposal. Recovery of used LWR fuel in a molten salt has been discussed earlier, Section 3.1.2.6., and the CEA has used hydrofluorination to process oxide from used nuclear fuel. ${ }^{80}$ Additionally, pyroprocessing has been used to extract actinides from $\mathrm{LiCl}-\mathrm{KCl}^{81}$, In a molten salt pyroprocess, actinides are collected at the cathode under an applied electrochemical potential. As fuel in the MSR is already in the salt form, a similar process could readily be applied.

Other industries are interested in recovery of metals from fluoride salts. For instance, extraction of rare earth elements from a fluoride salt electrolytic slag has been considered as a way to recover these valuable materials that would otherwise be lost. Various methods include dissolution in acid, roasting with $\mathrm{Ca}(\mathrm{OH})_{2}$ at temperatures up to $1000^{\circ} \mathrm{C}$, heating with $\mathrm{NaOH}$ at temperatures up to $500^{\circ} \mathrm{C}$ to form hydroxides, and silicate roasting to form water-insoluble rare earth silicates. In the silicate roasting case, after a roast of 1.5 hours at $850^{\circ} \mathrm{C}$, the lanthanides were converted to the silicate minerals. ${ }^{82}$ The soluble fluoride salt components were removed by washing. Recovery of lanthanides was stated to be over $90 \%$. Studies involving formation of uranyl silicates have been carried out, but this was done under hydrothermal conditions. ${ }^{83,84}$ An advantage of separations in the molten state is that large volumes of acidic waste water are not generated as found in actinide separations based on PUREX-type processes.

Electrochemical methods were mentioned earlier in the context of FP removal from salts. The separation of uranium by FLiNaK was studied jointly by a group in the Czech Republic and Slovakia. ${ }^{85}$ They were able to achieve some success in depositing uranium on a working nickel electrode, but only up to 25 mass $\%$. The process was very sensitive to the presence of oxygen in the salt.

\subsubsection{Radiolytic stability}

Besides the issue with solubility, another important reason to remove the halide from the salt is to impart radiolytic stability to the waste form. Dehalogenation would allow the use of waste forms that have already been assessed for high-level nuclear waste. Reaction with phosphates such as phosphoric acid, ammonium phosphate, or lithium-potassium phosphate converts the metallic chlorides to phosphate 
glasses, liberating ammonium chloride that can easily be removed, as it has a high volatility. This process has been demonstrated at the bench scale for chloride salts, and it is anticipated that it could work for fluoride salts based on thermodynamic stabilities. ${ }^{86}$ Rare-earth phosphates form a stable mineral, monazite or xenotine. Trapping of salt cations in zeolites is also being explored. ${ }^{87}$

\subsubsection{Potential forms}

Because of its solubility in water, the MSR salt is not a good medium for immobilization. Therefore, conversion to another form is necessary. Options include glass, ceramic, glass-ceramic, ${ }^{88}$ glass-bonded ceramic, and ceramic-metallic forms. Waste form possibilities were reviewed by Riley. ${ }^{51}$ Residue from pyroprocessing can be incorporated into a fluoride glass-ceramic waste from. Dehalogenation produces oxides, phosphate glasses, or borosilicate glasses. Zeolites can be hot pressed into low porosity ceramics. Phosphate minerals can be mixed with a glass to form a glass-composite material. The Glass Material Oxidation and Dissolution System (GMODS) developed for radioactive waste can handle many different materials, such as, metals, ceramics, and organics.$^{89,90}$ The material is dissolved in a mixture of glass and sacrificial molten lead oxide, oxidizing the transition metals and forming a glass waste form. Reduced metallic lead is recovered from the bottom of the furnace for recycling through the process. It is possible that this one-step process could also be applied to molten salts, but this has not yet been tested. There are many options for molten salt waste forms. These have not been demonstrated at the pilot scale, but several converge on technologies that have already been tested for pyroprocessing and other activities. The primary hazards are the high radiological fields and contamination that will necessitate processing in shielded facilities. Thus, operations and maintenance must be optimized for remote handling.

Waste structural materials will also be generated during reactor decommissioning. Graphite will be a major waste form in the case of thermal salt reactors, and it may be the limiting factor of the reactor lifetime. The graphite will be contaminated with FPs captured by recoil and fluoride from the salt itself. The graphite may also have a significant loading of tritium from activation of lithium in the core. Recovery of graphite by removing the tritium has been proposed and would greatly reduce the volume of the waste. ${ }^{91}$ Options for removal of tritium and other FPs have been evaluated by CARBOWASTE, and handling of graphite will follow procedures developed for other in-core graphite materials. ${ }^{92}$

Metals from the reactor core will also comprise a waste material and will be laden with reduced FP metals that plate out on colder surfaces in the core. Measures to decontaminate and reduce the size of metal waste include removal of entrained salt from structural materials including leachable FPs such as technetium. Any decontamination activity will be performed with remote handling but can take advantage of salt water solubility, so it is within the scope of current handling of nuclear materials. ${ }^{93}$

\section{FUEL SALT PROCESSING HAZARD TABLES}

Many of the MSR hazards discussed herein are common with other nuclear reactors, but specifics resulting from reactor design features such as molten fuel salt can change the relative importance of these concerns. Also, MSRs have distinctive attributes not found in other reactor types. This section provides a brief overview of an MSR's fuel hazards due to the liquid nature of its fuel. Fuel salt hazards are not limited to the core. They exist in all phases of operation, from initial fueling to waste storage and handling.

General reactor hazards such as change in reactivity margin due to mobile delayed neutron precursors are outside the scope of this report. In addition, categories of hazards such as exposure to radiation, the possibility of contamination, handling actinides in the form of oxides, and exposure to lead and graphite, are not explicitly listed in the hazard tables, as these are well known to nuclear regulators and reactor operators. 
Table 3 presents a compilation of identified MSR fuel salt processing hazards. Table 3 is divided into a series of sub-tables, each presenting fuel salt processing hazards of a different phase of MSR operation.

- Table 3a describes off-site nuclear fuel preparation and handling.

- Table $3 \mathrm{~b}$ describes onsite activities prior to criticality.

- Table $3 \mathrm{c}$ presents onsite hazards when the reactor is operating.

- Table $3 \mathrm{~d}$ describes activities during maintenance outages.

- Table 3e presents fuel salt processing and conditioning during operation.

- Table $3 \mathrm{f}$ presents hazards of activities after shutdown.

- Table $3 \mathrm{~g}$ presents hazards of waste form generation.

The hazard tables are all formatted the same: Each row refers to an activity such as a chemical process or monitoring activity. The activity is briefly described in the first column. The second column describes the salt or component being processed and the goals of the process. A reference to location in this report that provides additional details and context about the process is given in the third column. The fourth column lists important hazards associated with the activity. The state of knowledge about each activity is given in the fifth column in terms of its technical readiness level (TRL), ${ }^{94}$ and the $6^{\text {th }}$ column gives a qualitative assessment of the potential severity of the hazard to operations staff. In cases where multiple hazards are identified, the ranking is based on the most severe hazard. The final column lists ways that the hazards can be mitigated.

Many of the activities and hazards listed in Tables $3 \mathrm{a}-\mathrm{g}$ are repeated several times, i.e., monitoring of the off-gas system. This redundancy is deliberate, allowing each set of operations or each row within a set of operations to be considered individually. 
Table 3a. Off-site nuclear fuel preparation and handling

\begin{tabular}{|c|c|c|c|c|c|c|}
\hline $\begin{array}{l}\text { Physical or } \\
\text { chemical process }\end{array}$ & $\begin{array}{l}\text { Salt type and } \\
\text { process objective }\end{array}$ & $\begin{array}{l}\text { Relevant } \\
\text { report } \\
\text { sections }\end{array}$ & Key hazards & $\begin{array}{c}\begin{array}{c}\text { Qualitative } \\
\text { assessment }\end{array} \\
\text { TRL: } 1 \text { (low) } \\
\text { to } 9 \text { (high) }\end{array}$ & $\begin{array}{c}\text { Qualitative } \\
\text { severity } \\
\text { judgment } \\
\text { Rank: } 1 \text { (low) } \\
\text { to } 5 \text { (high) } \\
\end{array}$ & Mitigation strategies \\
\hline $\begin{array}{l}\text { - Salt synthesis } \\
\text { - Colex }\end{array}$ & ${ }^{7} \mathrm{Li}$ production & 3.1 .1 & $\begin{array}{l}\text { - Mercury: } \\
\text { - caustic (LiOH) }\end{array}$ & $\begin{array}{l}\text { 6: downgraded } \\
\text { due to lack of } \\
\text { practice for } \\
50+\text { years }\end{array}$ & 5 & $\begin{array}{l}\text { - Alternatives to using mercury are } \\
\text { being assessed }\end{array}$ \\
\hline $\begin{array}{l}\text { - Salt synthesis } \\
\text { - Electromigration }\end{array}$ & ${ }^{7} \mathrm{Li}$ production & 3.1 .1 & - Heat & 3 & 2 & \\
\hline $\begin{array}{l}\text { - Salt synthesis } \\
\text { - Crown ether } \\
\end{array}$ & ${ }^{7} \mathrm{Li}$ production & 3.1 .1 & $\begin{array}{l}\text { - Organic chemicals: } \\
\text { - caustic }\left(\mathrm{LiOH}_{\mathrm{aq}}\right) \\
\end{array}$ & 3 & 2 & \\
\hline $\begin{array}{l}\text { - Salt synthesis } \\
\text { - Liquid diffusion }\end{array}$ & ${ }^{37} \mathrm{Cl}$ production & 3.1 .1 & $\begin{array}{l}\text { - } \mathrm{CCl}_{4} \text {, chloroform } \\
\text { - Pressure: } 5 \text { bar }\end{array}$ & 3 & 4 & \\
\hline $\begin{array}{l}\text { - Salt synthesis } \\
\text { - Anion exchange } \\
\text { chromatography }\end{array}$ & ${ }^{37} \mathrm{Cl}$ production & 3.1 .1 & $\begin{array}{l}\text { - } \mathrm{HNO}_{3} \\
\text { - } \mathrm{AgNO}_{3}\end{array}$ & 3 & 2 & \\
\hline $\begin{array}{l}\text { - Salt synthesis } \\
\text { - } \mathrm{NaCl} \\
\text { crystallization } \\
\end{array}$ & ${ }^{37} \mathrm{Cl}$ production & 3.1 .1 & $\begin{array}{l}\text { - } 20-80 \mathrm{mT} \\
\text { magnetic field }\end{array}$ & 3 & 2 & \\
\hline $\begin{array}{l}\text { - Salt synthesis } \\
\text { - } \text { Reduction with } \\
\mathrm{CCl}_{4}\end{array}$ & $\begin{array}{l}\text { Conversion: } \\
\mathrm{UF}_{6} \text { to } \mathrm{UF}_{4}\end{array}$ & 3.1 .2 & $\begin{array}{l}\text { - Uranium } \\
\text { contamination } \\
\text { - } \mathrm{CCl}_{4}, \mathrm{Cl}_{2}, \mathrm{COCl}_{2} \\
\end{array}$ & 5 & 3 & $\begin{array}{l}\text { - Standard contamination control for } \\
\text { unirradiated materials } \\
\text { - Neutralize acidic and toxic gases }\end{array}$ \\
\hline $\begin{array}{l}\text { - Salt synthesis } \\
\text { - Reduction with } \\
\mathrm{NO}_{\mathrm{X}}\end{array}$ & $\begin{array}{l}\text { Conversion: } \\
\mathrm{UF}_{6} \text { to } \mathrm{UF}_{4}\end{array}$ & 3.1 .2 & $\begin{array}{l}\text { - Uranium } \\
\text { contamination } \\
\text { - } \mathrm{NO}_{\mathrm{X}}, \mathrm{NOF}, \mathrm{HF}, \mathrm{H}_{2} \\
\end{array}$ & 3 & 5 & $\begin{array}{l}\text { - Standard contamination control for } \\
\text { unirradiated materials } \\
\text { - Neutralize acidic and toxic gases }\end{array}$ \\
\hline $\begin{array}{l}\text { - Salt synthesis } \\
\text { - Fluorination }\end{array}$ & $\begin{array}{c}\text { Conversion: } \\
\text { oxides to fluorides }\end{array}$ & 3.1 .2 & $\begin{array}{l}\text { - } \mathrm{HF}, \mathrm{H}_{2} \\
\text { - } \mathrm{UO}_{2+\mathrm{x}}, \mathrm{ThO}_{2} \\
\text { contamination } \\
\end{array}$ & 9 & 4 & $\begin{array}{l}\text { - Standard contamination control for } \\
\text { unirradiated materials }\end{array}$ \\
\hline $\begin{array}{l}\text { - Salt synthesis } \\
\text { - Reaction with } \\
\mathrm{NH}_{4} \mathrm{HF}_{2} \\
\end{array}$ & $\begin{array}{l}\text { Conversion: } \\
\text { oxides to fluorides }\end{array}$ & 3.1 .2 & $\begin{array}{l}\text { - } \mathrm{ThO}_{2} \text { contamination } \\
\text { - } 400^{\circ} \mathrm{C} \\
\text { - } \mathrm{NH}_{4} \mathrm{~F}, \mathrm{NH}_{4} \mathrm{HF}_{2} \\
\end{array}$ & 3 & 2 & $\begin{array}{l}\text { - Standard contamination control for } \\
\text { unirradiated materials }\end{array}$ \\
\hline
\end{tabular}


Table 3a. Off-site nuclear fuel preparation and handling (continued)

\begin{tabular}{|c|c|c|c|c|c|c|}
\hline $\begin{array}{c}\text { Physical or } \\
\text { chemical process }\end{array}$ & $\begin{array}{c}\text { Salt type and } \\
\text { process objective }\end{array}$ & $\begin{array}{c}\text { Relevant } \\
\text { report } \\
\text { sections }\end{array}$ & Key hazards & $\begin{array}{c}\text { Qualitative } \\
\text { assessment } \\
\text { TRL: 1 (low) } \\
\text { to } 9 \text { (high) } \\
\end{array}$ & $\begin{array}{c}\text { Qualitative } \\
\text { severity } \\
\text { judgment } \\
\text { Rank: } 1 \text { (low) } \\
\text { to } 5 \text { (high) } \\
\end{array}$ & Mitigation strategies \\
\hline $\begin{array}{l}\text { - Salt purification } \\
\text { Hydrofluorination }\end{array}$ & $\begin{array}{c}\text { Removal of } \\
\text { oxides/hydroxides } \\
\text { from fluoride salts }\end{array}$ & 3.1 .1 & $\begin{array}{l}\text { - } \mathrm{H}_{2} / \mathrm{HF} \\
\text { - } \mathrm{Be} \text { if present as the } \\
\mathrm{BeF}_{2} \text { salt component } \\
\text { - } \mathrm{Heat}\left(650^{\circ} \mathrm{C}\right) \\
\quad \text { Contamination if } \\
\text { actinides present }\end{array}$ & 7 & 4 & $\begin{array}{c}\text { Standard contamination control for } \\
\text { unirradiated materials }\end{array}$ \\
\hline $\begin{array}{l}\text { - Salt purification } \\
\text { - Chlorination }\end{array}$ & $\begin{array}{c}\text { Removal of } \\
\text { oxides/hydroxides } \\
\text { from chloride salts }\end{array}$ & 3.1 .1 & $\begin{array}{l}\text { - } \mathrm{CCl}_{4}, \mathrm{Cl}_{2}, \mathrm{COCl}_{2} \text {, } \\
\mathrm{HCl} \\
\text { - Heat } \\
\text { - Contamination if } \\
\text { actinides present }\end{array}$ & 7 & 5 & $\begin{array}{l}\text { - Standard contamination control for } \\
\text { unirradiated materials }\end{array}$ \\
\hline $\begin{array}{l}\text { - Packaging and } \\
\text { transportation }\end{array}$ & $\begin{array}{l}\text { Actinides and } \\
\text { nonfissile } \\
\text { components }\end{array}$ & 3.3 & $\begin{array}{l}\text { - Contamination if } \\
\text { actinides present } \\
\text { - Air-sensitive } \\
\text { - Be (if present as } \\
\left.\mathrm{BeF}_{2}\right)\end{array}$ & 9 & 3 & - Double barrier container \\
\hline
\end{tabular}


Table 3b. Operations conducted on site prior to reactor operation (initial criticality)

\begin{tabular}{|c|c|c|c|c|c|c|}
\hline $\begin{array}{c}\text { Physical or chemical } \\
\text { process }\end{array}$ & $\begin{array}{c}\text { Salt type and } \\
\text { process objective }\end{array}$ & $\begin{array}{l}\text { Relevant } \\
\text { report } \\
\text { sections }\end{array}$ & Key hazards & $\begin{array}{c}\text { Qualitative } \\
\text { assessment } \\
\text { TRL: } 1 \text { (low) } \\
\text { to } 9 \text { (high) } \\
\end{array}$ & 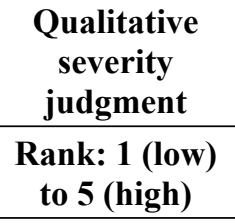 & Mitigation strategies \\
\hline $\begin{array}{l}\text { - Receipt of materials at } \\
\text { reactor site }\end{array}$ & $\begin{array}{l}\text { Actinides and } \\
\text { nonfissile } \\
\text { components }\end{array}$ & 3.3 & $\begin{array}{l}\text { - Contamination } \\
\text { - Air sensitive } \\
\text { - Be (if present as } \\
\left.\mathrm{BeF}_{2}\right)\end{array}$ & 9 & 2 & - Double barrier container \\
\hline $\begin{array}{l}\text { - Onsite storage prior to } \\
\text { loading }\end{array}$ & $\begin{array}{l}\text { Actinides and } \\
\text { nonfissile } \\
\text { components }\end{array}$ & 3.3 & $\begin{array}{l}\text { - Contamination } \\
\text { - Air sensitive } \\
\text { - } \mathrm{Be}(\text { if present as } \\
\left.\mathrm{BeF}_{2}\right) \\
\end{array}$ & 9 & 1 & - Double barrier container \\
\hline $\begin{array}{l}\text { - Preparation for use } \\
\text { - Making aliquots for } \\
\text { loading }\end{array}$ & $\begin{array}{l}\text { Actinide fluoride } \\
\text { and chloride salts }\end{array}$ & $\begin{array}{c}2.2 .1,2.2 .2 \\
3.2\end{array}$ & $\begin{array}{l}\text { - Contamination } \\
\text { - Air sensitive } \\
\text { - Criticality }\end{array}$ & 5 & 3 & $\begin{array}{l}\text { - Inert gas flush when transferring } \\
\text { salts } \\
\text { - Double barrier }\end{array}$ \\
\hline $\begin{array}{l}\text { - Core load prior to } \\
\text { criticality }\end{array}$ & $\begin{array}{l}\text { Nonfissile fluoride } \\
\text { and chloride salts }\end{array}$ & 2.2 & $\begin{array}{l}\text { - Air sensitive } \\
\text { - } \mathrm{Be}(\text { if present as } \\
\mathrm{BeF}_{2} \text { ) }\end{array}$ & 7 & 2 & $\begin{array}{l}\text { - Inert gas flush when transferring } \\
\text { salts } \\
\text { - Double barrier }\end{array}$ \\
\hline - Initial core load & $\begin{array}{c}\text { Fissile components } \\
\text { of fluoride and } \\
\text { chloride salts }\end{array}$ & 2.2 .1 & $\begin{array}{l}\text { - Contamination } \\
\text { - Air sensitive } \\
\text { - Criticality }\end{array}$ & 5 & 4 & $\begin{array}{l}\text { - Inert gas flush } \\
\text { - Double barrier }\end{array}$ \\
\hline $\begin{array}{l}\text { Online sampling of salt } \\
\text { during loading }\end{array}$ & $\begin{array}{c}\text { Fluorides, } \\
\text { chlorides, fuel salt, } \\
\text { coolant salt, flush } \\
\text { salt composition, } \\
\text { and mixing by } \\
\text { density } \\
\text { measurement }\end{array}$ & $4.2,4.3$ & $\begin{array}{l}\text { - Contamination } \\
\text { - Air sensitive } \\
\text { - Criticality } \\
\text { - Be (if present as } \\
\left.\mathrm{BeF}_{2}\right)\end{array}$ & 4 & 5 & $\begin{array}{l}\text { - Gamma, densitometer, control } \\
\text { rod measurements } \\
\text { - Inert gas flush } \\
\text { - Double barrier containment }\end{array}$ \\
\hline
\end{tabular}


Table 3c. Onsite fuel processing hazards during power operations

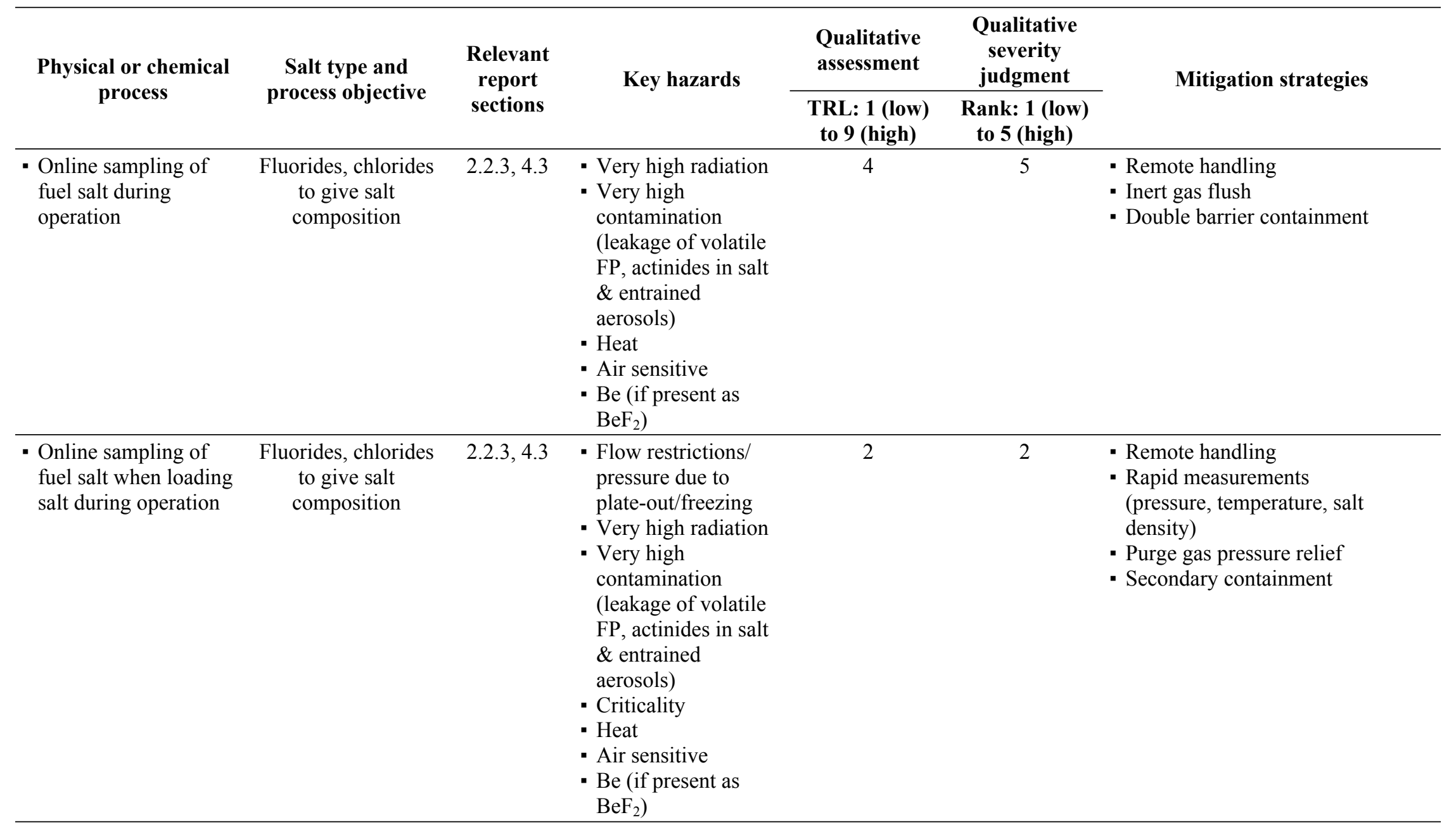


Table 3c. Onsite fuel processing hazards during power operations (continued)

\begin{tabular}{|c|c|c|c|c|c|c|}
\hline \multirow{2}{*}{$\begin{array}{c}\text { Physical or chemical } \\
\text { process }\end{array}$} & \multirow{2}{*}{$\begin{array}{c}\text { Salt type and } \\
\text { process objective }\end{array}$} & \multirow{2}{*}{$\begin{array}{c}\text { Relevant } \\
\text { report } \\
\text { sections }\end{array}$} & \multirow[t]{2}{*}{ Key hazards } & $\begin{array}{l}\text { Qualitative } \\
\text { assessment }\end{array}$ & $\begin{array}{c}\text { Qualitative } \\
\text { severity } \\
\text { judgment } \\
\end{array}$ & \multirow[t]{2}{*}{ Mitigation strategies } \\
\hline & & & & $\begin{array}{l}\text { TRL: } 1 \text { (low) } \\
\text { to } 9 \text { (high) }\end{array}$ & $\begin{array}{l}\text { Rank: } 1 \text { (low) } \\
\text { to } 5 \text { (high) }\end{array}$ & \\
\hline 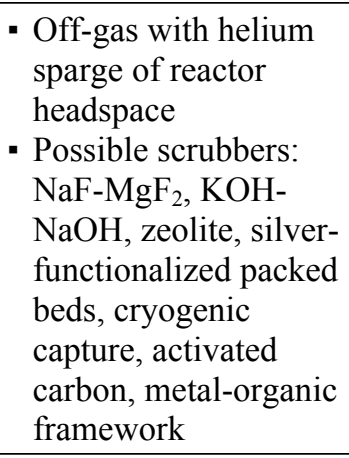 & $\begin{array}{l}\text { Fluoride, chlorides } \\
\text { to reduce fission } \\
\text { gas build-up in the } \\
\text { headspace and to } \\
\text { reduce emissions }\end{array}$ & 4.4 & $\begin{array}{l}\text { - Flow } \\
\text { restrictions/pressure } \\
\text { - Very high radiation } \\
\text { - Heat }\end{array}$ & 2 & 4 & $\begin{array}{l}\text { - Remote and rapid measurements } \\
\text { for rad and process variables } \\
\text { (temperature, pressure, flow etc. } \\
\text { - Purge gas pressure relief } \\
\text { - Secondary containment }\end{array}$ \\
\hline $\begin{array}{l}\text { - Online sampling of } \\
\text { off-gas }\end{array}$ & Fluorides, chlorides & 4.4 & $\begin{array}{l}\text { - Flow restrictions/ } \\
\text { pressure } \\
\text { - Very high radiation } \\
\text { - Very high } \\
\text { contamination } \\
\text { (leakage of volatile } \\
\text { FP, actinides in } \\
\text { entrained salt } \\
\text { aerosols) } \\
\text { - Heat } \\
\text { - Halogens } \\
\text { - } \mathrm{Be}_{\text {(if present as }} \\
\mathrm{BeF}_{2} \text { ) }\end{array}$ & 2 & 2 & $\begin{array}{l}\text { - Remote handling and rapid } \\
\text { measurements for rad and process } \\
\text { variables } \\
\text { (temperature pressure, flow, etc.) } \\
\text { - Purge gas pressure relief } \\
\text { - Secondary containment }\end{array}$ \\
\hline $\begin{array}{l}\text { - Salt filtering } \\
\text { - Online removal of } \\
\text { precipitates }\end{array}$ & $\begin{array}{c}\text { Fluoride } \\
\text { (FP + graphite), } \\
\text { chloride salts (FP) }\end{array}$ & 4.5 & $\begin{array}{l}\text { - Flow restrictions/ } \\
\text { pressure } \\
\text { - Very high radiation }\end{array}$ & 2 & 3 & $\begin{array}{l}\text { Rapid online measurements for } \\
\text { process variables } \\
\text { (temperature, pressure, salt flow, } \\
\text { etc.) }\end{array}$ \\
\hline
\end{tabular}


Table 3c. Onsite fuel processing hazards during power operations (continued)

\begin{tabular}{|c|c|c|c|c|c|c|}
\hline \multirow{2}{*}{$\begin{array}{c}\text { Physical or chemical } \\
\text { process }\end{array}$} & \multirow{2}{*}{$\begin{array}{l}\text { Salt type and } \\
\text { process objective }\end{array}$} & \multirow{2}{*}{$\begin{array}{c}\text { Relevant } \\
\text { report } \\
\text { sections }\end{array}$} & \multirow[t]{2}{*}{ Key hazards } & $\begin{array}{l}\text { Qualitative } \\
\text { assessment }\end{array}$ & $\begin{array}{c}\text { Qualitative } \\
\text { severity } \\
\text { judgment }\end{array}$ & \multirow[t]{2}{*}{ Mitigation strategies } \\
\hline & & & & $\begin{array}{l}\text { TRL: } 1 \text { (low) } \\
\text { to } 9 \text { (high) }\end{array}$ & $\begin{array}{c}\text { Rank: } 1 \text { (low) } \\
\text { to } 5 \text { (high) }\end{array}$ & \\
\hline $\begin{array}{l}\text { - Refueling } \\
\text { - Reductant addition }\end{array}$ & $\begin{array}{l}\text { Chlorides: } \mathrm{Mg} \text {, } \\
\text { redox compensation }\end{array}$ & 2.2 .2 & $\begin{array}{l}\text { - Mg pyrophoricity } \\
\text { - Very high radiation } \\
\text { - Very high } \\
\text { contamination } \\
\text { (leakage of volatile } \\
\text { FP, actinides in salt) } \\
\text { - Heat } \\
\text { - Halogens } \\
\text { - Corrosive } \\
\text { - Flow restrictions in } \\
\text { sparge }\end{array}$ & 2 & 5 & $\begin{array}{l}\text { - Remote handling } \\
\text { - Rapid online measurements for } \\
\text { process variables } \\
\text { (temperature, pressure flow, etc.) } \\
\text { - Pressure relief } \\
\text { - Secondary containment }\end{array}$ \\
\hline $\begin{array}{l}\text { - Refueling } \\
\text { - Reductant addition }\end{array}$ & $\begin{array}{l}\text { Fluorides: Be, } \\
\text { redox compensation }\end{array}$ & 2.2 .2 & $\begin{array}{l}\text { - } \mathrm{Be} \text { as } \mathrm{Be}, \mathrm{BeF}_{2} \\
\text { - Very high radiation } \\
\text { - Very high } \\
\text { contamination } \\
\text { (leakage of volatile } \\
\text { FP, actinides in salt) } \\
\text { - Heat } \\
\text { - Halogens } \\
\text { - Corrosive } \\
\text { - Flow restrictions in } \\
\text { helium sparge }\end{array}$ & 2 & 5 & $\begin{array}{l}\text { - Remote handling } \\
\text { - Rapid online measurements for } \\
\text { process variables (temperature, } \\
\text { pressure, flow, etc.) } \\
\text { - Pressure relief } \\
\text { - Secondary containment }\end{array}$ \\
\hline
\end{tabular}


Table 3c. Onsite fuel processing hazards during power operations (continued)

\begin{tabular}{|c|c|c|c|c|c|c|}
\hline $\begin{array}{c}\text { Physical or chemical } \\
\text { process }\end{array}$ & $\begin{array}{c}\text { Salt type and } \\
\text { process objective }\end{array}$ & $\begin{array}{l}\text { Relevant } \\
\text { report } \\
\text { sections }\end{array}$ & Key hazards & $\begin{array}{c}\text { Qualitative } \\
\text { assessment } \\
\text { TRL: } 1 \text { (low) } \\
\text { to } 9 \text { (high) }\end{array}$ & $\begin{array}{c}\begin{array}{c}\text { Qualitative } \\
\text { severity } \\
\text { judgment }\end{array} \\
\text { Rank: } 1 \text { (low) } \\
\text { to } 5 \text { (high) } \\
\end{array}$ & Mitigation strategies \\
\hline $\begin{array}{l}\text { - Refueling } \\
\text { - Fissile material } \\
\text { addition }\end{array}$ & $\begin{array}{l}\text { Chlorides, e.g., } \\
\mathrm{UCl}_{3}\end{array}$ & 2.2 .2 & $\begin{array}{l}\text { - Very high radiation } \\
\text { - Very high } \\
\text { contamination } \\
\text { (leakage of volatile } \\
\text { FP, actinides in salt) } \\
\text { - Heat } \\
\text { - Halogens } \\
\text { - Corrosive } \\
\text { - Flow restrictions in } \\
\text { sparge } \\
\text { - Accountability }\end{array}$ & 2 & 5 & $\begin{array}{l}\text { - Remote handling } \\
\text { - Rapid online measurements for } \\
\text { process variables (temperature, } \\
\text { pressure, flow, etc.) } \\
\text { - Pressure relief } \\
\text { - Secondary containment }\end{array}$ \\
\hline $\begin{array}{l}\text { - Refueling } \\
\text { - Fissile material } \\
\text { addition }\end{array}$ & Fluorides, e.g., $\mathrm{UF}_{4}$ & $2.2 .2,2.2 .3$ & $\begin{array}{l}\text { - } \text { Be as } \mathrm{BeF}_{2} \\
\text { - Very high radiation } \\
\text { - Very high } \\
\text { contamination } \\
\text { (leakage of volatile } \\
\text { FP, actinides in salt) } \\
\text { - Heat } \\
\text { - Halogens } \\
\text { - Corrosive } \\
\text { - Flow restrictions in } \\
\text { helium sparge } \\
\text { - Accountability }\end{array}$ & 5 & 5 & $\begin{array}{l}\text { - Remote handling } \\
\text { - Rapid online measurements for } \\
\text { process variables (temperature, } \\
\text { pressure, flow, etc.) } \\
\text { - Pressure relief } \\
\text { - Secondary containment }\end{array}$ \\
\hline
\end{tabular}


Table 3c. Onsite fuel processing hazards during power operations (continued)

\begin{tabular}{|c|c|c|c|c|c|c|}
\hline \multirow{2}{*}{$\begin{array}{c}\text { Physical or chemical } \\
\text { process }\end{array}$} & \multirow{2}{*}{$\begin{array}{c}\text { Salt type and } \\
\text { process objective }\end{array}$} & \multirow{2}{*}{$\begin{array}{l}\text { Relevant } \\
\text { report } \\
\text { sections }\end{array}$} & \multirow[t]{2}{*}{ Key hazards } & $\begin{array}{l}\text { Qualitative } \\
\text { assessment }\end{array}$ & $\begin{array}{c}\text { Qualitative } \\
\text { severity } \\
\text { judgment }\end{array}$ & \multirow[t]{2}{*}{ Mitigation strategies } \\
\hline & & & & $\begin{array}{l}\text { TRL: } 1 \text { (low) } \\
\text { to } 9 \text { (high) }\end{array}$ & $\begin{array}{l}\text { Rank: } 1 \text { (low) } \\
\text { to } 5 \text { (high) }\end{array}$ & \\
\hline $\begin{array}{l}\text { - Defueling } \\
\text { - Spent fuel removal } \\
\text { (small amounts) }\end{array}$ & $\begin{array}{l}\text { Chlorides and } \\
\text { fluorides }\end{array}$ & 2.2 .2 & $\begin{array}{l}\text { - Very high radiation } \\
\text { - Very high } \\
\text { contamination } \\
\text { (leakage of volatile } \\
\text { FP, actinides in salt) } \\
\text { - Heat } \\
\text { - Halogens } \\
\text { - Corrosive } \\
\text { - Flow restrictions in } \\
\text { - sparge } \\
\text { - Accountability } \\
\text { - Be (if present as } \\
\mathrm{BeF}_{2} \text { ) }\end{array}$ & 2 & 5 & $\begin{array}{l}\text { - Remote handling } \\
\text { - Rapid online measurements for } \\
\text { process variables (temperature, } \\
\text { pressure, flow, etc.) } \\
\text { - Pressure relief } \\
\text { - Secondary containment } \\
\text { - Recycle/waste stream established } \\
\text { prior to operation }\end{array}$ \\
\hline
\end{tabular}


Table 3d. Activities during maintenance outages

\begin{tabular}{|c|c|c|c|c|c|c|}
\hline \multirow{2}{*}{$\begin{array}{c}\text { Physical or chemical } \\
\text { process }\end{array}$} & \multirow{2}{*}{$\begin{array}{c}\text { Salt type and } \\
\text { process objective }\end{array}$} & \multirow{2}{*}{$\begin{array}{c}\text { Relevant } \\
\text { report } \\
\text { sections }\end{array}$} & \multirow[t]{2}{*}{ Key hazards } & $\begin{array}{l}\text { Qualitative } \\
\text { assessment }\end{array}$ & $\begin{array}{c}\text { Qualitative } \\
\text { severity } \\
\text { judgment }\end{array}$ & \multirow[t]{2}{*}{ Mitigation strategies } \\
\hline & & & & $\begin{array}{l}\text { TRL: } 1 \text { (low) } \\
\text { to } 9 \text { (high) }\end{array}$ & $\begin{array}{c}\text { Rank: } 1 \text { (low) } \\
\text { to } 5 \text { (high) } \\
\end{array}$ & \\
\hline $\begin{array}{l}\text { - Off-gas with helium } \\
\text { sparge of process head } \\
\text { space } \\
\text { - Possible scrubbers: } \\
\mathrm{NaF}-\mathrm{MgF}_{2}, \mathrm{KOH}- \\
\mathrm{NaOH}, \text { zeolite, silver- } \\
\text { functionalized packed } \\
\text { beds, cryogenic } \\
\text { capture, activated } \\
\text { carbon, metal-organic } \\
\text { framework }\end{array}$ & $\begin{array}{l}\text { Fluorides, chlorides } \\
\text { to reduce fission } \\
\text { gas build-up in } \\
\text { headspace and } \\
\text { reduce emissions }\end{array}$ & 4.4 & $\begin{array}{l}\text { - Flow restrictions/ } \\
\text { pressure } \\
\text { - Very high radiation } \\
\text { - Heat }\end{array}$ & 2 & 5 & $\begin{array}{l}\text { - Remote, rapid analysis of } \\
\text { process variables, scrubbers, } \\
\text { hold-up beds } \\
\text { - Purge gas pressure relief } \\
\text { - Secondary containment }\end{array}$ \\
\hline $\begin{array}{l}\text { - Online sampling of } \\
\text { off-gas }\end{array}$ & Fluorides, chlorides & 4.4 & $\begin{array}{l}\text { - Flow restrictions/ } \\
\text { pressure } \\
\text { - Very high radiation } \\
\text { - Very high } \\
\text { contamination } \\
\text { (leakage of volatile } \\
\text { FP, actinides in } \\
\text { entrained salt } \\
\text { aerosols) } \\
\text { - Heat } \\
\text { - Halogens } \\
\text { - Be (if present as } \\
\left.\mathrm{BeF}_{2}\right)\end{array}$ & 2 & 4 & $\begin{array}{l}\text { - Remote handling and rapid } \\
\text { online measurements for process } \\
\text { variables (temperature, pressure, } \\
\text { flow, etc.) } \\
\text { - Pressure relief } \\
\text { - Secondary containment }\end{array}$ \\
\hline
\end{tabular}


Table 3d. Activities during maintenance outages (continued)

\begin{tabular}{|c|c|c|c|c|c|c|}
\hline \multirow{2}{*}{$\begin{array}{c}\text { Physical or chemical } \\
\text { process }\end{array}$} & \multirow{2}{*}{$\begin{array}{c}\text { Salt type and } \\
\text { process objective }\end{array}$} & \multirow{2}{*}{$\begin{array}{c}\text { Relevant } \\
\text { report } \\
\text { sections }\end{array}$} & \multirow[t]{2}{*}{ Key hazards } & $\begin{array}{l}\text { Qualitative } \\
\text { assessment }\end{array}$ & $\begin{array}{c}\text { Qualitative } \\
\text { severity } \\
\text { judgment }\end{array}$ & \multirow[t]{2}{*}{ Mitigation strategies } \\
\hline & & & & $\begin{array}{c}\text { TRL: } 1 \text { (low) } \\
\text { to } 9 \text { (high) }\end{array}$ & $\begin{array}{c}\text { Rank: } 1 \text { (low) } \\
\text { to } 5 \text { (high) }\end{array}$ & \\
\hline $\begin{array}{l}\text { - Salt filtering } \\
\text { - Maintenance/ } \\
\text { replacement } \\
\text { of filters }\end{array}$ & $\begin{array}{c}\text { Fluoride, } \\
\text { chloride salts }\end{array}$ & 4.5 & $\begin{array}{l}\text { - Very high radiation } \\
\text { - Very high } \\
\text { contamination } \\
\text { (leakage of volatile } \\
\text { FP, actinides in } \\
\text { entrained salt) } \\
\text { - Heat } \\
\text { - Halogens } \\
\text { - Be (if present as } \\
\mathrm{BeF}_{2} \text { ) }\end{array}$ & 2 & 5 & $\begin{array}{l}\text { - Remote handling } \\
\text { - Rapid online measurement of } \\
\text { process variables (temperature, } \\
\text { pressure, etc.) } \\
\text { - Secondary containment }\end{array}$ \\
\hline
\end{tabular}


Table 3e. Fuel salt processing and conditioning during operations

\begin{tabular}{|c|c|c|c|c|c|c|}
\hline \multirow{2}{*}{$\begin{array}{c}\text { Physical or chemical } \\
\text { process }\end{array}$} & \multirow{2}{*}{$\begin{array}{c}\text { Salt type and } \\
\text { process objective }\end{array}$} & \multirow{2}{*}{$\begin{array}{l}\text { Relevant } \\
\text { report } \\
\text { sections }\end{array}$} & \multirow[t]{2}{*}{ Key hazards } & $\begin{array}{l}\text { Qualitative } \\
\text { assessment }\end{array}$ & $\begin{array}{c}\text { Qualitative } \\
\text { severity } \\
\text { judgment }\end{array}$ & \multirow[t]{2}{*}{ Mitigation strategies } \\
\hline & & & & $\begin{array}{c}\text { TRL: } 1 \text { (low) to } \\
9 \text { (high) }\end{array}$ & $\begin{array}{l}\text { Rank: } 1 \text { (low) } \\
\text { to } 5 \text { (high) }\end{array}$ & \\
\hline $\begin{array}{l}\text { - Salt processing online } \\
\text { - Actinide recovery, } \\
\text { protactinium and FP } \\
\text { separation. } \\
\text { - Control of redox } \\
\text { chemistry if required. } \\
\text { - Processing options } \\
\text { given in sections below } \\
\text { Salt returned to reactor }\end{array}$ & Fluorides & $2.2 .3,4.6 .2$ & $\begin{array}{l}\text { - Very high radiation } \\
\text { - Very high } \\
\text { contamination } \\
\text { (leakage of volatile } \\
\text { FP, actinides in salt) } \\
\text { - Heat } \\
\text { - Halogens } \\
\text { - Corrosive } \\
\text { - Off-gas handling } \\
\text { - Be as BeF } 2 \\
\text { - Rad waste generation }\end{array}$ & 2 & 5 & $\begin{array}{l}\text { - Remote handling } \\
\text { - Rapid online measurements for } \\
\text { process variables } \\
\text { (temperature, etc.) } \\
\text { - Secondary containment } \\
\text { - Shielded waste storage }\end{array}$ \\
\hline $\begin{array}{l}\text { - Salt processing online } \\
\text { - Actinide recovery and } \\
\text { FP separation } \\
\text { - Adding } \mathrm{UCl}_{3} \text { to } \\
\text { solubilize metallic FPs } \\
\text { - Processing options } \\
\text { given in sections below } \\
\text { - Salt returned to reactor }\end{array}$ & Chlorides & 4.6 .1 & $\begin{array}{l}\text { - Very high radiation } \\
\text { - Very high } \\
\text { contamination } \\
\text { (leakage of volatile } \\
\text { FP, actinides in salt) } \\
\text { - Heat } \\
\text { - Halogens } \\
\text { - Corrosive } \\
\text { - Off-gas handling } \\
\text { - UCl }{ }_{3} \text {, precipitation U } \\
\text { metal } \\
\text { - Rad waste generation }\end{array}$ & 2 & 5 & $\begin{array}{l}\text { - Remote handling } \\
\text { - Rapid online measurements for } \\
\text { process variables } \\
\text { (temperature, etc.) } \\
\text { - Secondary containment } \\
\text { - Shielded waste storage }\end{array}$ \\
\hline
\end{tabular}


Table 3e. Fuel salt processing and conditioning during operations (continued)

\begin{tabular}{|c|c|c|c|c|c|c|}
\hline \multirow{2}{*}{$\begin{array}{c}\text { Physical or chemical } \\
\text { process }\end{array}$} & \multirow{2}{*}{$\begin{array}{c}\text { Salt type and } \\
\text { process objective }\end{array}$} & \multirow{2}{*}{$\begin{array}{c}\text { Relevant } \\
\text { report } \\
\text { sections }\end{array}$} & \multirow[t]{2}{*}{ Key hazards } & $\begin{array}{l}\text { Qualitative } \\
\text { assessment }\end{array}$ & $\begin{array}{c}\text { Qualitative } \\
\text { severity } \\
\text { judgment } \\
\end{array}$ & \multirow[t]{2}{*}{ Mitigation strategies } \\
\hline & & & & $\begin{array}{l}\text { TRL: } 1 \text { (low) to } \\
9 \text { (high) }\end{array}$ & $\begin{array}{l}\text { Rank: } 1 \text { (low) } \\
\text { to } 5 \text { (high) }\end{array}$ & \\
\hline $\begin{array}{l}\text { - Salt processing } \\
\text { - Electrochemical }\end{array}$ & Chlorides & $4.6 .1,4.7 .1$ & $\begin{array}{l}\text { - Very high radiation } \\
\text { - Very high } \\
\text { contamination } \\
\text { (leakage of volatile } \\
\text { FP, actinides in salt) } \\
\text { - Heat } \\
\text { - Halogens } \\
\text { - Corrosive } \\
\text { - Off-gas handling } \\
\text { - Electrical }\end{array}$ & 5 & 5 & $\begin{array}{l}\text { - Remote handling } \\
\text { - Rapid online measurements for } \\
\text { process variables } \\
\text { (temperature, etc.) } \\
\text { - Secondary containment } \\
\text { - Shielded waste storage }\end{array}$ \\
\hline $\begin{array}{l}\text { - Salt processing } \\
\text { - Electrochemical }\end{array}$ & Fluorides & $4.6 .2,4.7 .1$ & $\begin{array}{l}\text { - } \mathrm{Be} \text { as } \mathrm{BeF}_{2} \\
\text { - Very high radiation } \\
\text { - Very high } \\
\text { contamination } \\
\text { (leakage of volatile } \\
\quad \text { FP, actinides in salt) } \\
\text { - Heat } \\
\text { - Halogens } \\
\text { - Corrosive } \\
\text { - Off-gas handling } \\
\text { - Electrical }\end{array}$ & 2 & 5 & $\begin{array}{l}\text { - Remote handling } \\
\text { - Rapid online measurements for } \\
\text { process variables } \\
\text { (temperature, etc.) } \\
\text { - Secondary containment } \\
\text { - Shielded waste storage }\end{array}$ \\
\hline $\begin{array}{l}\text { - Salt processing } \\
\text { - Fluorination }\end{array}$ & Fluorides & 2.2 .3 & $\begin{array}{l}\text { - } \mathrm{F}_{2}, \mathrm{Be} \text { as } \mathrm{BeF}_{2} \\
\text { - Very high radiation } \\
\text { - Very high } \\
\text { contamination } \\
\text { (leakage of volatile } \\
\text { FP, actinides) } \\
\text { - Heat } \\
\text { - Halogens } \\
\text { - Corrosive } \\
\text { - Off-gas handling }\end{array}$ & 2 & 5 & $\begin{array}{l}\text { - Remote handling } \\
\text { - Rapid online measurements for } \\
\text { process variables } \\
\text { (temperature, etc.) } \\
\text { - Secondary containment } \\
\text { - Shielded waste storage }\end{array}$ \\
\hline
\end{tabular}


Table 3e. Fuel salt processing and conditioning during operations (continued)

\begin{tabular}{|c|c|c|c|c|c|c|}
\hline \multirow{2}{*}{$\begin{array}{c}\text { Physical or chemical } \\
\text { process }\end{array}$} & \multirow{2}{*}{$\begin{array}{c}\text { Salt type and } \\
\text { process objective }\end{array}$} & \multirow{2}{*}{$\begin{array}{l}\text { Relevant } \\
\text { report } \\
\text { sections }\end{array}$} & \multirow[t]{2}{*}{ Key hazards } & $\begin{array}{l}\text { Qualitative } \\
\text { assessment }\end{array}$ & $\begin{array}{l}\text { Qualitative } \\
\text { severity } \\
\text { judgment }\end{array}$ & \multirow[t]{2}{*}{ Mitigation strategies } \\
\hline & & & & $\begin{array}{l}\text { TRL: } 1 \text { (low) to } \\
9 \text { (high) }\end{array}$ & $\begin{array}{l}\text { Rank: } 1 \text { (low) } \\
\text { to } 5 \text { (high) }\end{array}$ & \\
\hline $\begin{array}{l}\text { - Salt processing } \\
\text { - Reductive extraction }\end{array}$ & Chlorides & 4.6 .1 & $\begin{array}{l}\text { - Very high radiation } \\
\text { - Very high } \\
\text { contamination } \\
\text { (leakage of volatile } \\
\text { FP) } \\
\text { - Precipitation of U } \\
\text { metal } \\
\text { - Heat } \\
\text { - Halogens } \\
\text { - Corrosive } \\
\text { - Off-gas handling } \\
\text { - Electrical } \\
\end{array}$ & 2 & 5 & $\begin{array}{l}\text { - Remote handling } \\
\text { - Rapid online measurements for } \\
\text { process variables } \\
\text { (temperature, etc.) } \\
\text { - Secondary containment } \\
\text { - Shielded waste storage }\end{array}$ \\
\hline $\begin{array}{l}\text { - Salt processing } \\
\text { - Reductive extraction }\end{array}$ & Fluorides & 4.6 .2 & $\begin{array}{l}\text { - } \mathrm{BeF}_{2} \\
\text { - Very high radiation } \\
\text { - Very high } \\
\text { contamination } \\
\text { (leakage of volatile } \\
\text { FP) } \\
\text { - Heat } \\
\text { - Halogens, HF } \\
\text { - Corrosive } \\
\text { - Off-gas handling } \\
\text { - Electrical } \\
\text { - Molten metals } \\
\end{array}$ & 2 & 5 & $\begin{array}{l}\text { - Remote handling } \\
\text { - Rapid online measurements for } \\
\text { process variables } \\
\text { (temperature, etc.) } \\
\text { - Secondary containment } \\
\text { - Shielded waste storage }\end{array}$ \\
\hline
\end{tabular}


Table 3e. Fuel salt processing and conditioning during operations (continued)

\begin{tabular}{|c|c|c|c|c|c|c|}
\hline \multirow{2}{*}{$\begin{array}{c}\text { Physical or chemical } \\
\text { process }\end{array}$} & \multirow[t]{2}{*}{$\begin{array}{c}\text { Salt type and } \\
\text { process objective }\end{array}$} & \multirow{2}{*}{$\begin{array}{l}\text { Relevant } \\
\text { report } \\
\text { sections }\end{array}$} & \multirow[t]{2}{*}{ Key hazards } & $\begin{array}{r}\text { Qualitative } \\
\text { assessment }\end{array}$ & $\begin{array}{c}\text { Qualitative } \\
\text { severity } \\
\text { judgment }\end{array}$ & \multirow[t]{2}{*}{ Mitigation strategies } \\
\hline & & & & $\begin{array}{c}\text { TRL: } 1 \text { (low) to } \\
9 \text { (high) }\end{array}$ & $\begin{array}{l}\text { Rank: } 1 \text { (low) } \\
\text { to } 5 \text { (high) }\end{array}$ & \\
\hline $\begin{array}{l}\text { - Salt processing } \\
\text { - Vacuum distillation }\end{array}$ & Chlorides & 4.6 .3 & $\begin{array}{l}\text { - Very high radiation } \\
\text { - Very high } \\
\text { contamination } \\
\text { (volatile FP, } \\
\text { actinides) } \\
\text { - Heat } \\
\text { - Halogens } \\
\text { - Corrosive } \\
\text { - Off-gas handling }\end{array}$ & 4 & 4 & $\begin{array}{l}\text { - Remote handling } \\
\text { - Rapid online measurements for } \\
\text { process variables (temperature, } \\
\text { pressure, vacuum, flow ...) } \\
\text { - Secondary containment } \\
\text { - Shielded waste storage }\end{array}$ \\
\hline $\begin{array}{l}\text { - Salt processing } \\
\text { - Vacuum distillation }\end{array}$ & Fluorides & 4.6 .3 & $\begin{array}{l}\text { - } \text { Be as } \mathrm{BeF}_{2} \\
\text { - Very high radiation } \\
\text { - Very high } \\
\text { contamination } \\
\text { (volatile FP, } \\
\text { actinides) } \\
\text { - Heat } \\
\text { - Halogens } \\
\text { - Corrosive } \\
\text { - Off-gas handling }\end{array}$ & 6 & 4 & $\begin{array}{l}\text { - Remote handling } \\
\text { - Rapid online measurements for } \\
\text { process variables (temperature, } \\
\text { pressure, vacuum, flow...) } \\
\text { - Secondary containment } \\
\text { - Shielded waste storage }\end{array}$ \\
\hline $\begin{array}{l}\text { - Salt processing } \\
\text { - Oxidative precipitation }\end{array}$ & Chlorides & 4.6 .4 & $\begin{array}{l}\text { - } \mathrm{O}_{2} \text { (combustion/ } \\
\text { explosion) } \\
\text { - } 750^{\circ} \mathrm{C} \\
\text { - Very high radiation } \\
\text { - Very high } \\
\text { contamination } \\
\text { (leakage of volatile } \\
\text { FP) } \\
\text { - Heat } \\
\text { - Halogens } \\
\text { - Corrosive }\end{array}$ & 2 & 5 & $\begin{array}{l}\text { - Pressure relief } \\
\text { - Flow monitoring } \\
\text { - Remote handling } \\
\text { - Secondary containment } \\
\text { - Online instrumentation }\end{array}$ \\
\hline
\end{tabular}


Table 3e. Fuel salt processing and conditioning during operations (continued)

\begin{tabular}{|c|c|c|c|c|c|c|}
\hline \multirow{2}{*}{$\begin{array}{c}\text { Physical or chemical } \\
\text { process }\end{array}$} & \multirow{2}{*}{$\begin{array}{c}\text { Salt type and } \\
\text { process objective }\end{array}$} & \multirow{2}{*}{$\begin{array}{l}\text { Relevant } \\
\text { report } \\
\text { sections }\end{array}$} & \multirow[t]{2}{*}{ Key hazards } & $\begin{array}{l}\text { Qualitative } \\
\text { assessment }\end{array}$ & $\begin{array}{c}\text { Qualitative } \\
\text { severity } \\
\text { judgment }\end{array}$ & \multirow[t]{2}{*}{ Mitigation strategies } \\
\hline & & & & $\begin{array}{c}\text { TRL: } 1 \text { (low) to } \\
9 \text { (high) }\end{array}$ & $\begin{array}{l}\text { Rank: } 1 \text { (low) } \\
\text { to } 5 \text { (high) } \\
\end{array}$ & \\
\hline $\begin{array}{l}\text { - Salt processing } \\
\text { - Melt crystallization }\end{array}$ & Chlorides & 4.6 .5 & $\begin{array}{l}\text { - Very high radiation } \\
\text { - Very high } \\
\text { contamination } \\
\text { (leakage of volatile } \\
\text { FP) } \\
\text { - Heat } \\
\text { - Halogens } \\
\text { - Corrosive } \\
\text { - Salt transfer and } \\
\text { handling }\end{array}$ & 5 & 5 & $\begin{array}{l}\text { - Remote handling } \\
\text { - Secondary containment } \\
\text { - Online instrumentation } \\
\text { - Accountability for solid isotopes }\end{array}$ \\
\hline
\end{tabular}


Table 3f. Activities after shutdown

\begin{tabular}{|c|c|c|c|c|c|c|}
\hline $\begin{array}{c}\text { Physical or chemical } \\
\text { process }\end{array}$ & $\begin{array}{c}\text { Salt type and } \\
\text { process objective }\end{array}$ & $\begin{array}{l}\text { Relevant } \\
\text { report } \\
\text { sections }\end{array}$ & Key hazards & $\begin{array}{c}\text { Qualitative } \\
\text { assessment } \\
\text { TRL: } 1 \text { (low) } \\
\text { to } 9 \text { (high) }\end{array}$ & $\begin{array}{c}\begin{array}{c}\text { Qualitative } \\
\text { severity } \\
\text { judgment }\end{array} \\
\text { Rank: 1 (low) } \\
\text { to } 5 \text { (high) }\end{array}$ & Mitigation strategies \\
\hline $\begin{array}{l}\text { - Online sampling of } \\
\text { off-gas }\end{array}$ & Fluorides, chlorides & 4.4 & $\begin{array}{l}\text { - Flow restrictions/ } \\
\text { pressure } \\
\text { - Very high radiation } \\
\text { - Heat }\end{array}$ & 2 & 3 & $\begin{array}{l}\text { - Remote and } \\
\text { - rapid measurements for rad and } \\
\text { process variables (temperature, } \\
\text { pressure, flow, etc.) } \\
\text { - Purge gas pressure relief } \\
\text { - Secondary containment }\end{array}$ \\
\hline $\begin{array}{l}\text { - Core unloading } \\
\text { - Spent fuel removal by } \\
\text { pressurization }\end{array}$ & $\begin{array}{l}\text { Chlorides and } \\
\text { fluorides }\end{array}$ & Shutdown & $\begin{array}{l}\text { - Very high radiation } \\
\text { - Very high } \\
\text { contamination } \\
\text { - Heat } \\
\text { - Halogens } \\
\text { - Corrosive } \\
\text { - Pressure } \\
\text { - Be (as BeF } \mathrm{F}_{2} \text { if } \\
\text { present) }\end{array}$ & 2 & 5 & $\begin{array}{l}\text { - Pressure relief } \\
\text { - Flow monitoring } \\
\text { - Remote handling } \\
\text { - Secondary containment } \\
\text { - Online instrumentation } \\
\text { - Recycle/waste stream established } \\
\text { prior to operation }\end{array}$ \\
\hline $\begin{array}{l}\text { - Removal from } \\
\text { containment/ } \\
\text { drain tanks }\end{array}$ & $\begin{array}{l}\text { Spent salt, } \\
\text { fluorides and } \\
\text { chlorides }\end{array}$ & Shutdown & $\begin{array}{l}\text { - Very high radiation } \\
\text { - Very high } \\
\text { contamination } \\
\text { - Heat } \\
\text { - Halogens } \\
\text { - Corrosive } \\
\text { - Be (as } \mathrm{BeF}_{2} \text { if } \\
\text { present) }\end{array}$ & 2 & 4 & $\begin{array}{l}\text { - Remote handling } \\
\text { - Secondary containment } \\
\text { - Online instrumentation }\end{array}$ \\
\hline
\end{tabular}


Table 3f. Activities after shutdown (continued)

\begin{tabular}{|c|c|c|c|c|c|c|}
\hline $\begin{array}{c}\text { Physical or chemical } \\
\text { process }\end{array}$ & $\begin{array}{c}\text { Salt type and } \\
\text { process objective }\end{array}$ & $\begin{array}{l}\text { Relevant } \\
\text { report } \\
\text { sections }\end{array}$ & Key hazards & $\begin{array}{c}\text { Qualitative } \\
\text { assessment } \\
\text { TRL: } 1 \text { (low) } \\
\text { to } 9 \text { (high) }\end{array}$ & $\begin{array}{c}\begin{array}{c}\text { Qualitative } \\
\text { severity } \\
\text { judgment }\end{array} \\
\text { Rank: 1 (low) } \\
\text { to } 5 \text { (high) }\end{array}$ & Mitigation strategies \\
\hline - Onsite storage & $\begin{array}{l}\text { Spent salt, } \\
\text { fluorides and } \\
\text { chlorides }\end{array}$ & Shutdown & $\begin{array}{l}\text { - Very high radiation } \\
\text { - Very high } \\
\text { contamination } \\
\text { - Heat } \\
\text { - Halogens } \\
\text { - Corrosive } \\
\text { - Be (as BeF } 2 \text { if } \\
\text { present) } \\
\text { - F } \text { F }_{2} \text { and other } \\
\text { fluorine-bearing } \\
\text { species from } \\
\text { radiolysis } \\
\text { - U metal } \\
\text { precipitation upon } \\
\text { remelting }\end{array}$ & 2 & 3 & $\begin{array}{l}\text { - Remote handling } \\
\text { - Secondary containment } \\
\text { - Online instrumentation }\end{array}$ \\
\hline $\begin{array}{l}\text { Packaging and } \\
\text { transportation } \\
\text { to off-site facility }\end{array}$ & $\begin{array}{l}\text { Spent salt, } \\
\text { fluorides and } \\
\text { chlorides }\end{array}$ & Shutdown & $\begin{array}{l}\text { - Very high radiation } \\
\text { - Very high } \\
\text { contamination } \\
\text { - Heat } \\
\text { - Halogens } \\
\text { - Corrosive } \\
\text { - Be (if present as } \\
\left.\mathrm{BeF}_{2}\right)\end{array}$ & 2 & 4 & $\begin{array}{l}\text { - Remote handling } \\
\text { - Secondary containment } \\
\text { - Online instrumentation }\end{array}$ \\
\hline
\end{tabular}


Table 3g. Waste form preparation

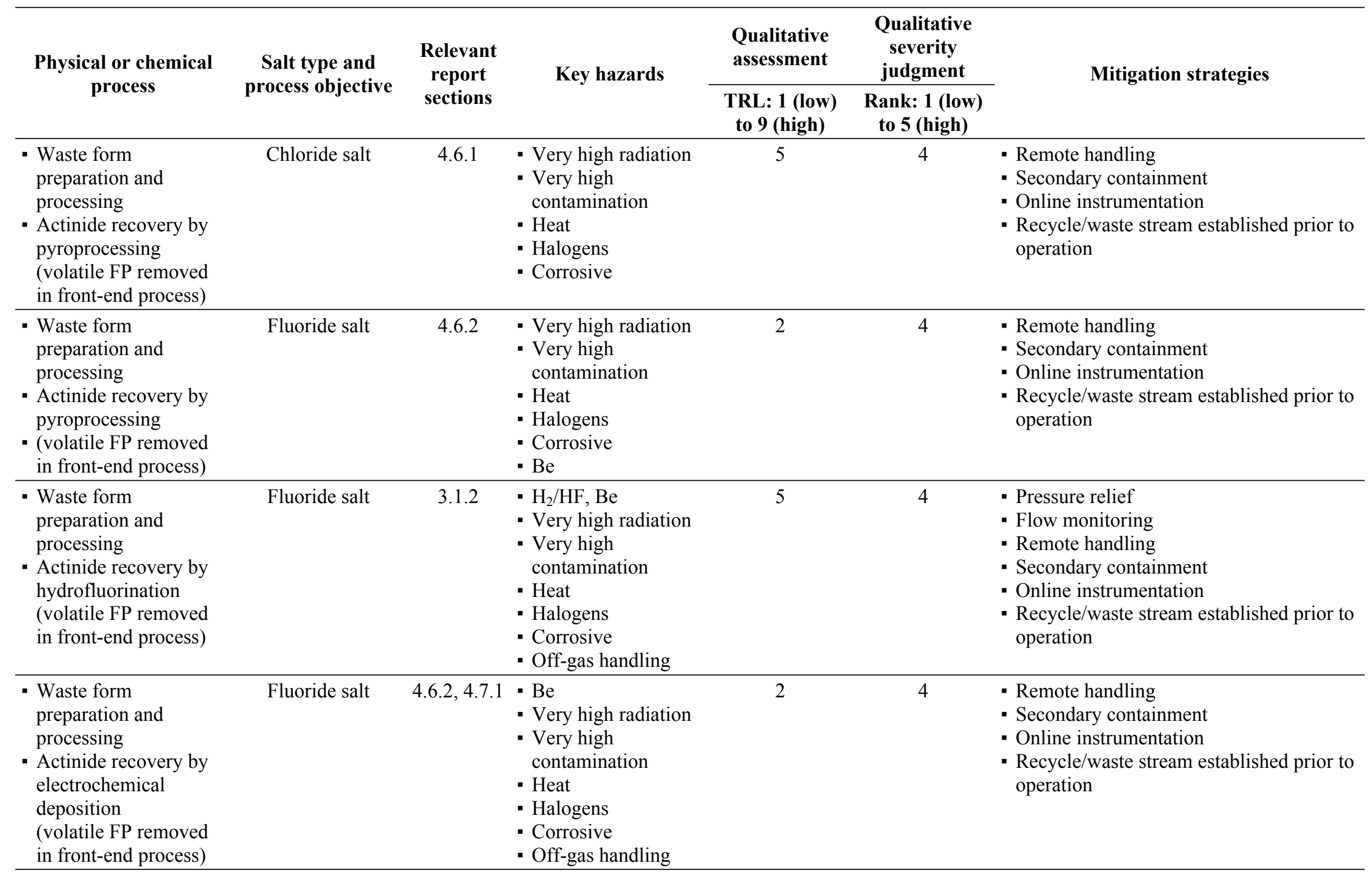


Table 3g. Waste form preparation (continued)

\begin{tabular}{|c|c|c|c|c|c|c|}
\hline $\begin{array}{c}\text { Physical or chemical } \\
\text { process }\end{array}$ & $\begin{array}{c}\text { Salt type and } \\
\text { process objective }\end{array}$ & $\begin{array}{c}\text { Relevant } \\
\text { report } \\
\text { sections }\end{array}$ & Key hazards & $\begin{array}{l}\text { Qualitative } \\
\text { assessment } \\
\text { TRL: } 1 \text { (low) } \\
\text { to } 9 \text { (high) } \\
\end{array}$ & $\begin{array}{l}\text { Qualitative } \\
\text { severity } \\
\text { judgment } \\
\text { Rank: } 1 \text { (low) } \\
\text { to } 5 \text { (high) } \\
\end{array}$ & Mitigation strategies \\
\hline $\begin{array}{l}\text { - Waste form } \\
\text { preparation and } \\
\text { processing } \\
\text { - Actinide recovery by } \\
\text { dissolution in acid } \\
\text { (volatile FP removed } \\
\text { in front-end process) }\end{array}$ & Fluoride salt & 4.7 .1 & $\begin{array}{l}\text { - Be } \\
\text { - Very high radiation } \\
\text { - Very high } \\
\text { contamination } \\
\text { - Heat } \\
\text { - Halogens } \\
\text { - Corrosive } \\
\text { - Off-gas handling }\end{array}$ & 8 & 4 & $\begin{array}{l}\text { - Remote handling } \\
\text { - Secondary containment } \\
\text { - Online instrumentation } \\
\text { - Recycle/waste stream established prior to } \\
\text { operation }\end{array}$ \\
\hline $\begin{array}{l}\text { - Waste form } \\
\text { preparation and } \\
\text { processing } \\
\text { - Actinide recovery by } \\
\text { roasting with } \mathrm{Ca}(\mathrm{OH})_{2} \\
\text { (volatile FP removed } \\
\text { in front-end process) }\end{array}$ & Fluoride salt & 4.7 .1 & $\begin{array}{l}\text { - Be } \\
\text { - Very high radiation } \\
\text { - Very high } \\
\text { contamination } \\
\text { - Heat } \\
\text { - Halogens } \\
\text { - Corrosive }\end{array}$ & 2 & 4 & $\begin{array}{l}\text { - Remote handling } \\
\text { - Secondary containment } \\
\text { - Online instrumentation } \\
\text { - Recycle/waste stream established prior to } \\
\text { operation }\end{array}$ \\
\hline $\begin{array}{l}\text { - Waste form } \\
\text { preparation and } \\
\text { processing } \\
\text { - Actinide recovery by } \\
\text { heating with } \mathrm{NaOH} \\
\text { (volatile FP removed } \\
\text { in front-end process) }\end{array}$ & Fluoride salt & 4.7 .1 & $\begin{array}{l}\text { - Be } \\
\text { - Very high radiation } \\
\text { - Very high } \\
\text { contamination } \\
\text { - Heat } \\
\text { - Halogens } \\
\text { - Corrosive }\end{array}$ & 2 & 4 & $\begin{array}{l}\text { - Remote handling } \\
\text { - Secondary containment } \\
\text { - Online instrumentation } \\
\text { - Recycle/waste stream established prior to } \\
\text { operation }\end{array}$ \\
\hline $\begin{array}{l}\text { - Waste form } \\
\text { preparation and } \\
\text { processing } \\
\text { - Actinide recovery by } \\
\text { silicate roasting } \\
\text { (volatile FP removed } \\
\text { in front-end process) }\end{array}$ & Fluoride salt & 4.7 .1 & $\begin{array}{l}\text { - } \mathrm{Be}, \mathrm{SiO}_{2} \\
\text { - Very high radiation } \\
\text { - Very high } \\
\text { contamination } \\
\text { (volatile FP) } \\
\text { - Heat } \\
\text { - Halogens } \\
\text { - Corrosive }\end{array}$ & 2 & 4 & $\begin{array}{l}\text { - Remote handling } \\
\text { - Secondary containment } \\
\text { - Online instrumentation } \\
\text { - Recycle/waste stream established prior to } \\
\text { operation }\end{array}$ \\
\hline
\end{tabular}


Table 3g. Waste form preparation (continued)

\begin{tabular}{|c|c|c|c|c|c|c|}
\hline $\begin{array}{c}\text { Physical or chemical } \\
\text { process }\end{array}$ & $\begin{array}{c}\text { Salt type and } \\
\text { process objective }\end{array}$ & $\begin{array}{l}\text { Relevant } \\
\text { report } \\
\text { sections }\end{array}$ & Key hazards & $\begin{array}{c}\text { Qualitative } \\
\text { assessment } \\
\text { TRL: } 1 \text { (low) } \\
\text { to } 9 \text { (high) } \\
\end{array}$ & $\begin{array}{l}\text { Qualitative } \\
\text { severity } \\
\text { judgment } \\
\text { Rank: } 1 \text { (low) } \\
\text { to } 5 \text { (high) } \\
\end{array}$ & Mitigation strategies \\
\hline $\begin{array}{l}\text { - Waste form } \\
\text { preparation, }{ }^{7} \mathrm{Li} \\
\text { recovery (volatile FP } \\
\text { removed in front-end } \\
\text { process) }\end{array}$ & Fluoride salt & 3.1 .1 & $\begin{array}{l}\text { - Be } \\
\text { - Very high radiation } \\
\text { - Very high } \\
\text { contamination } \\
\text { - Heat } \\
\text { - Halogens } \\
\text { - Corrosive }\end{array}$ & 2 & 4 & $\begin{array}{l}\text { - Remote handling } \\
\text { - Secondary containment } \\
\text { - Online instrumentation } \\
\text { - Recycle/waste stream established prior to } \\
\text { operation }\end{array}$ \\
\hline $\begin{array}{l}\text { - Waste form } \\
\text { preparation } \\
\text { - }{ }^{37} \mathrm{Cl} \text { recovery } \\
\text { (volatile FP removed } \\
\text { in front-end process) }\end{array}$ & Chloride salt & 3.1 .1 & $\begin{array}{l}\text { - Very high radiation } \\
\text { - Very high } \\
\text { contamination } \\
\text { - Heat } \\
\text { - Halogens } \\
\text { - Corrosive }\end{array}$ & 2 & 4 & $\begin{array}{l}\text { - Remote handling } \\
\text { - Secondary containment } \\
\text { - Online instrumentation } \\
\text { - Recycle/waste stream established prior to } \\
\text { operation }\end{array}$ \\
\hline $\begin{array}{l}\text { - Waste form } \\
\text { preparation } \\
\text { - Dehalogenation }\end{array}$ & Chloride salt & 4.7 .2 & $\begin{array}{l}\text { - Very high radiation } \\
\text { - Very high } \\
\text { contamination } \\
\text { - Heat } \\
\text { - Volatile chlorides } \\
\text { - Corrosive } \\
\end{array}$ & 2 & 4 & $\begin{array}{l}\text { - Remote handling } \\
\text { - Secondary containment } \\
\text { - Online instrumentation } \\
\text { - Recycle/waste stream established prior to } \\
\text { operation }\end{array}$ \\
\hline $\begin{array}{l}\text { - Waste form } \\
\text { preparation } \\
\text { - Dehalogenation }\end{array}$ & Fluoride salt & 4.7 .2 & $\begin{array}{l}\text { - Be } \\
\text { - Very high radiation } \\
\text { - Very high } \\
\text { contamination } \\
\text { - Heat } \\
\text { - Volatile fluorides } \\
\text { - Corrosive }\end{array}$ & 2 & 5 & $\begin{array}{l}\text { - Remote handling } \\
\text { - Secondary containment } \\
\text { - Online instrumentation } \\
\text { - Recycle/waste stream established prior to } \\
\text { operation }\end{array}$ \\
\hline $\begin{array}{l}\text { - Waste form } \\
\text { preparation } \\
\text { - Glass ceramic }\end{array}$ & $\begin{array}{l}\text { Pyroprocessed } \\
\text { dehalogenated } \\
\text { salt residue }\end{array}$ & 4.7 .3 & $\begin{array}{l}\text { - Be (if relevant) } \\
\text { - Very high radiation } \\
\text { - Very high } \\
\text { contamination } \\
\text { - Heat }\end{array}$ & 2 & 4 & $\begin{array}{l}\text { - Remote handling } \\
\text { - Secondary containment } \\
\text { - Online instrumentation }\end{array}$ \\
\hline
\end{tabular}


Table 3g. Waste form preparation (continued)

\begin{tabular}{|c|c|c|c|c|c|c|}
\hline $\begin{array}{c}\text { Physical or chemical } \\
\text { process }\end{array}$ & $\begin{array}{c}\text { Salt type and } \\
\text { process objective }\end{array}$ & $\begin{array}{l}\text { Relevant } \\
\text { report } \\
\text { sections }\end{array}$ & Key hazards & $\begin{array}{c}\text { Qualitative } \\
\text { assessment } \\
\text { TRL: } 1 \text { (low) } \\
\text { to } 9 \text { (high) }\end{array}$ & $\begin{array}{c}\text { Qualitative } \\
\text { severity } \\
\text { judgment } \\
\text { Rank: } 1 \text { (low) } \\
\text { to } 5 \text { (high) }\end{array}$ & Mitigation strategies \\
\hline $\begin{array}{l}\text { - Waste form } \\
\text { preparation } \\
\text { - Oxide }\end{array}$ & $\begin{array}{l}\text { Pyroprocessed } \\
\text { dehalogenated } \\
\text { salt residue }\end{array}$ & 4.7 .3 & $\begin{array}{l}\text { - Be (if relevant) } \\
\text { - Very high radiation } \\
\text { - Very high } \\
\text { contamination } \\
\text { - Heat }\end{array}$ & 2 & 4 & $\begin{array}{l}\text { - Remote handling } \\
\text { - Secondary containment } \\
\text { - Online instrumentation }\end{array}$ \\
\hline $\begin{array}{l}\text { - Waste form } \\
\text { preparation } \\
\text { - Phosphate glass }\end{array}$ & Salt residue & 4.7 .2 & $\begin{array}{l}\text { - Very high radiation } \\
\text { - Very high } \\
\text { contamination } \\
\text { - Heat } \\
\text { - Corrosive } \\
\text { - Be, } \mathrm{NH}_{4} \mathrm{Cl}(\mathrm{g}) \\
\text { (if relevant) } \\
\text { - Phosphoric acid, etc. }\end{array}$ & 2 & 5 & $\begin{array}{l}\text { - Remote handling } \\
\text { - Secondary containment } \\
\text { - Online instrumentation }\end{array}$ \\
\hline $\begin{array}{l}\text { - Waste form } \\
\text { preparation } \\
\text { - Borosilicate glass }\end{array}$ & $\begin{array}{l}\text { Dehalogenated salt } \\
\text { residue }\end{array}$ & 4.7 .3 & $\begin{array}{l}\text { - Very high radiation } \\
\text { - Very high } \\
\text { contamination } \\
\text { - Heat }\end{array}$ & 2 & 4 & $\begin{array}{l}\text { - Remote handling } \\
\text { - Secondary containment } \\
\text { - Online instrumentation }\end{array}$ \\
\hline $\begin{array}{l}\text { - Waste form } \\
\text { preparation } \\
\text { - zeolites }\end{array}$ & $\begin{array}{l}\text { Dehalogenated salt } \\
\text { residue }\end{array}$ & 4.7 .2 & $\begin{array}{l}\text { - Very high radiation } \\
\text { - Very high } \\
\text { contamination } \\
\text { - Heat }\end{array}$ & 2 & 4 & $\begin{array}{l}\text { - Remote handling } \\
\text { - Secondary containment } \\
\text { - Online instrumentation }\end{array}$ \\
\hline $\begin{array}{l}\text { - Waste form } \\
\text { preparation } \\
\text { - Glass composite }\end{array}$ & Salt glass & 4.7 .3 & $\begin{array}{l}\text { - Very high radiation } \\
\text { - Very high } \\
\text { contamination } \\
\text { - Heat }\end{array}$ & 2 & 4 & $\begin{array}{l}\text { - Remote handling } \\
\text { - Secondary containment } \\
\text { - Online instrumentation }\end{array}$ \\
\hline $\begin{array}{l}\text { - Waste form } \\
\text { preparation } \\
\text { - Glass material } \\
\text { oxidation and } \\
\text { dissolution system } \\
\text { (GMODS) }\end{array}$ & $\begin{array}{l}\text { Metals and } \\
\text { ceramic waste }\end{array}$ & 4.7 .3 & $\begin{array}{l}\text { - Pb } \\
\text { - Heat } \\
\text { - Very high radiation } \\
\text { - Very high } \\
\text { contamination }\end{array}$ & 2 & 5 & $\begin{array}{l}\text { - Remote handling } \\
\text { - Secondary containment } \\
\text { - Online instrumentation }\end{array}$ \\
\hline
\end{tabular}


Table 3g. Waste form preparation (continued)

\begin{tabular}{|c|c|c|c|c|c|c|}
\hline $\begin{array}{c}\text { Physical or chemical } \\
\text { process }\end{array}$ & $\begin{array}{c}\text { Salt type and } \\
\text { process objective }\end{array}$ & $\begin{array}{l}\text { Relevant } \\
\text { report } \\
\text { sections }\end{array}$ & Key hazards & $\begin{array}{c}\text { Qualitative } \\
\text { assessment } \\
\text { TRL: } 1 \text { (low) } \\
\text { to } 9 \text { (high) }\end{array}$ & $\begin{array}{c}\text { Qualitative } \\
\text { severity } \\
\text { judgment } \\
\text { Rank: } 1 \text { (low) } \\
\text { to } 5 \text { (high) }\end{array}$ & Mitigation strategies \\
\hline $\begin{array}{l}\text { - Waste form } \\
\text { preparation } \\
\text { - Tritium removal }\end{array}$ & $\begin{array}{c}\text { Graphite } \\
\text { (fluoride salts) }\end{array}$ & 4.7 .3 & $\begin{array}{l}\text { - Very high radiation } \\
\text { - Very high } \\
\text { contamination } \\
\text { - Be } \\
\text { - Graphite fines }\end{array}$ & 5 & 3 & $\begin{array}{l}\text { - Remote handling } \\
\text { - Secondary containment } \\
\text { - Online instrumentation }\end{array}$ \\
\hline $\begin{array}{l}\text { - Waste form } \\
\text { preparation } \\
\text { - Washing to remove } \\
\text { FPs }\end{array}$ & Structural metals & 4.7 .3 & $\begin{array}{l}\text { - Very high } \\
\text { contamination } \\
\text { - Very high radiation }\end{array}$ & 7 & 4 & $\begin{array}{l}\text { - Remote handling } \\
\text { - Secondary containment } \\
\text { - Online instrumentation }\end{array}$ \\
\hline
\end{tabular}




\section{SUMMARY}

This report provides a review of the hazards associated with liquid-fueled MSR fuel-processing operations. Fuel salt processing involves a wide range of hazards depending on the fuel salt, processing operation, fissile material concentration, radiation level, and presence of other toxic or hazardous materials. The hazards are summarized in a set of tables that include a relative ranking of the hazards and references to sections of the report which provide additional information and context. The steps in MSR fuel processing operations are substantially different from those for solid uranium oxide fuel fabrication and handling. A distinctive feature of MSRs is their ability to quasi-continuously refuel and adjust the fuel salt chemistry. Hence, fuel processing for liquid-fueled MSRs is more closely connected to reactor operations than would be the case for solid fueled systems.

MSR designs are not yet fully mature; nor are the designs for the primary and ancillary support systems for the synthesis and treatment of molten salt fuel. An estimate of the relative maturity (TRL score) of the processes is also included in this report's hazard table. The overall requirements for fuel processing operations, however, are reasonably well known, and the report provides overviews of likely fuel salt processing steps.

An important limitation of this report derives from the fact that only two relatively small MSR test reactors have ever been operated. Some systems and activities can be extrapolated from prior small-scale MSRs, and some can be extrapolated from non-nuclear, larger scale halide salt use. Large-scale fuel-salt facilities, however, may involve equipment and hazards not seen at smaller scales. Also, key reactorspecific hazards such as inadvertent criticality while performing initial fuel transfer into the reactor vessel have no direct antecedents in solid fueled reactors.

Liquid MSR fuel processing includes steps that are more closely coupled with reactor operations than steps used for fuel processing in solid fuel reactors. Consequently, fuel processing hazards are not as distinct from reactor safety as they are in solid fuel reactors, and this report includes some overlap with reactor accidents. 
${ }^{1}$ W. R. Grimes, D. R. Cuneo, F. F. Blankenship, G. W. Keilholtz, H. F. Poppendiek, and M. T. Robinson, "Chemical Aspects of Molten-Fluoride-Salt Reactor Fuels," Chapter 12 in Fluid Fuel Reactors, Addison-Wesley Publishing Company, Inc., assigned to General Manager, United States Atomic Energy Commission, 1958.

${ }^{2}$ M. Martin, M. Aufiero, E. Greenspan, and M. Fratoni. "Feasibility of Breed-and-Burn Molten Salt Reactor," ANS Transactions, 116, 1174-1365, 2017.

${ }^{3}$ James H. Shaffer, "Preparation and Handling of Salt Mixtures for the Molten Salt Reactor Experiment," ORNL-4616, 1971.

${ }^{4}$ E. F. Joseph, F. L. Daley, B. A. Hannaford, and E. L. Youngblood, "Aircraft Nuclear Propulsion Fluoride Fuel Preparation Facility," ORNL-CF-54-6-126, 1954.

${ }^{5}$ W. B. Cottrell, H. E. Hungerford, J. K. Leslie, and J. L. Meem, "Operation of the Aircraft Reactor Experiment," ORNL-1845 (Del.), 1955.

${ }^{6}$ R. B. Gallaher. "Operation of the Sampler-Enricher in the Molten Salt Reactor Experiment," ORNL-TM-3524, 1971.

${ }^{7}$ R. C. Robertson, MSRE Design and Operations Report - Part I, Description of Reactor Design, Chapter 7, "Sampler-Enricher System," ORNL-TM-728, 1965.

${ }^{8}$ M. W. Rosenthal, R. B. Briggs, and P. R. Kasten, "Molten-Salt Reactor Program Semiannual Program Progress Report for Period Ending February 28, 1970," ORNL-4548, 1970.

${ }^{9}$ R. B. Lindauer, Processing of the MSRE Flush and Fuel Salts, ORNL-TM-2578, 1969.

${ }^{10}$ K. Clusius and G. Dickel, "Das Trennrohr. II. Trennung der Chlorisotope," Z. Phys. Chem. B44, 451-473, 1939.

11 A.Z. Kranz and W.W. Watson, "Chlorine isotope separation by thermal diffusion”, Phys. Rev. 91(6), 1469-1472, 1953.

${ }^{12}$ G. D. Rabinovich and V. P. Ivakhnik. "Chlorine isotope separation by liquid-phase thermal diffusion." Soviet Atomic Energy 45(3), 879-882, 1978

${ }^{13}$ M. Musashi, T. Oi, and H. G. M. Eggenkamp. "Experimental determination of chlorine isotope separation factor by anionexchange chromatography." Analytica Chimica Acta 508.1: 37-40, 2004.

${ }^{14}$ V. Myshkin, S. Makarevich, A. Grigoriev, I. Zaguzin, and D. Gamov, "Research of the ${ }^{35} \mathrm{Cl} /{ }^{37} \mathrm{Cl}$ isotope concentration distribution over the volume of $\mathrm{NaCl}$ crystals grown from an aqueous solution in a magnetic field," AIP Conference Proceedings 1938, 020005 (2018); https://doi.org/10.1063/1.5027212.

${ }^{15}$ R. E. Thoma, "Chemical Aspects of MSRE Operations,” ORNL-4658, 1971.

${ }^{16}$ E. L. Compere, S. S. Kirslis, E. G. Bohlmann, F. F. Blankenship, and W. R. Grimes. "Fission product behavior in the molten salt reactor experiment," ORNL-4865, 1975.

${ }^{17}$ G. Goldberg, A. S. Meyer, Jr., and J. C. White. "Determination of oxides in fluoride salts by high-temperature fluorination with potassium bromotetrafluoride," Analytical Chemistry 32(3), 314-317, 1960.

${ }^{18}$ R. B. Briggs. "Molten-salt reactor program semiannual progress report for period ending February 28," ORNL-3936, p. 154, 1966.

${ }^{19}$ S.H. Smiley, D.C. Brater. "Conversion of uranium hexafluoride to uranium tetrafluoride”, in Progress in Nuclear Energy, Series III, Process Chemistry 2, 171-183, 1958.

${ }^{20}$ J. S. Nairn, D. A. Collins, and J. C. Taylor. "The Reduction of Uranium Hexafluoride by Carbon Tetrachloride," P/300, in Proceedings of the Second United Nations International Conference on the Peaceful Uses of Atomic Energy, Vol.4, Production of Nuclear Materials and Isotopes, 191-195, September 1-13, 1958.

${ }^{21}$ D. A. Collins et al., "Production of Uranium Tetrafluoride," US Patent 2,932,554, April 12, 1960

${ }^{22}$ N. P. Galkin, B. N. Sudarikov, V. A. Zaitsev, D. A. Vlasov, and V. G. Kosarev. "A Study of the Properties of Uranium Hexafluoride in Organic Solvents," Atomnaya Énergiya 10(2), 143-148, February 1961.

${ }^{23}$ P. R. Ogle, J. R. Geichman, and S. S. Trond. "Reactions of molybdenum, tungsten, and uranium hexafluorides with nitrogen compounds, I. Nitrous and nitric oxides," GAT-T-552/Rev.1, 1959.

${ }^{24}$ J. R. Geichman, E. A. Smith, L. R. Swaney, and P. R. Ogle. "Hexafluorides of molybdenum, tungsten and uranium, II. Reactions with liguid and gaseous dinitrogen tetroxide," GAT-T-970, 1962.

25 J. R. Geichman, L. R. Swaney, and P. R. Ogle. "Hexafluorides of molybdenum, tungsten and uranium, III. Reactions with nitrogen dioxide and nitrogen oxyhalides," GAT-T-971, 1962.

${ }^{26}$ D. A. Collins et al. "Production of Uranium Tetrafluoride," US Patent 2,932,554, April 12, 1960.

${ }^{27}$ W. E. Hobbs, "Method of Preparing Uranium Pentafluoride," US Patent 3,035,894, May 22, 1962.

${ }^{28}$ P. Aleksandrov, E. B. Gordon, A. V. Ivanov, A. A. Kotov and V. E. Smirnov. "Reduction of uranium hexafluoride to tetrafluoride by using the hydrogen atoms," Journal of Physics: Conference Series 751, 2016.

${ }^{29}$ C. E. Larsen. "Methods of preparing anhydrous tuballoy tetrachloride," Clinton Engineering Works, Tennessee Eastman Corporation, AECD-4125, 1946.

30 J. A. Hermann et al. "Uranium (IV) chloride," Inorganic Syntheses 5, 143, 1957.

${ }^{31}$ T. Schleid, G. Meyer, and L. R. Morss. J. Less Common Metals 132, 69-77, 1987.

${ }^{32}$ C. E. Larson, "The role of chemistry in the Oak Ridge electromagnetic project", Bull. Hist. Chem. 28(2), 101-109.

${ }^{33}$ L. R. Avens, S. G. Bott, D. L. Clark, A. P. Sattelberger, J. G. Watkin, and B. D. Zwick. "A convenient entry into trivalent actinide chemistry: synthesis and characterization of $\mathrm{AnI}_{3}(\mathrm{THF})_{4}$ and $\mathrm{An}\left[\mathrm{N}\left(\mathrm{SiMe}_{3}\right)_{2}\right]_{3}(\mathrm{An}=\mathrm{U}, \mathrm{Np}, \mathrm{Pu})$ " Inorganic Chemistry 33, 2248-2256, 1994. 
${ }^{34}$ C. D. Carmichael, N. A. Jones, and P. L. Arnold. "Low-valent uranium iodides: straightforward solution syntheses of UI $\mathrm{UI}_{3}$ and $\mathrm{UI}_{4}$ etherates," Inorganic Chemistry 47, 8577-8579, 2008.

${ }^{35}$ M. J. Monreal, R. K. Thomson, T. Cantat, N. E. Travia, B. L. Scott, and J. L. Kiplinger. "UI $\left(1,4-\right.$ dioxane $_{2},\left[\mathrm{UCl}_{4}(1,4-\right.$ dioxane $)]_{2}$, and $\mathrm{UI}_{3}(1,4 \text {-dioxane })_{1.5}$ : Stable and versatile starting materials for low-and high-valent uranium chemistry," Organometallics 20, 2031-2038, 2011.

${ }^{36}$ H. S. La Pierre, F. W. Heinemann, and K. Meyer. "Well-defined molecular uranium(III) chloride complexes," Chemical Communication 50, 3962-3964, 2014.

${ }^{37}$ B. N. Wani, S. J. Patwe, U.R.K. Rao, and K.S. Venkateswarlu. "Fluorination of oxides of uranium and thorium by ammonium hydrogen fluoride," J Fluorine Chemistry 44, 177-185, 1989.

${ }^{38}$ E. Capelli. "Thermodynamic Characterization of Salt Components for Molten Salt Reactor Fuel," PhD TU Delft, Delft, Netherlands, 2016.

${ }^{39}$ P. Taylor et al. "Mu*STAR ADSR Fuel Conversion Facility Evaluation and Cost Analysis," ORNL/TM-2018/989, Oak Ridge National Laboratory, Oak Ridge, TN, 2019.

${ }^{40} \mathrm{D}$. Watanabe et al. "Experimental study on elemental behaviors in fluorination of nuclear spent fuel with flame reactor," Journal of Nuclear Science and Technology 53 (4), 513-520, 2016.

${ }^{41}$ J. Uhlir, M. Marcek, and J. Škarohlíd, "Current progress in R\&D of Fluoride Volatility Method," SciVerse ScienceDirect Procedia Chemistry 7, 110-115, 2012.

42 R. D. Scheele and A. M. Casella, Assessment of the Use of Nitrogen Trifluoride for Purifying Coolant and Heat Transfer Salts in the Fluoride Salt-Cooled High-Temperature Reactor, PNNL-19793, Pacific Northwest National Laboratory, Richland, Washington, September 2010.

${ }^{43}$ G. I. Cathers, "Uranium Recovery for Spent Fuel by Dissolution in Fused Salt and Fluorination," Nuclear Science and Engineering 2(6): 768-777, 1957.

44 J. A. Fredricksen, L. O. Gilpatrick, and C. J. Barton. "Solubility of Cesium Trifluoride in Molten Mixtures of LiF, BeF 2 , and ThF," ORNL-TM-2335, 1969.

${ }^{45}$ C. J. Barton. "Solubility of Plutonium Trifluoride in Fused-Alkali Fluoride-Beryllium Fluoride Mixtures," J. Phys. Chem. 64 (3): 306-309, 1960. doi: 10.1021/j100832a005

${ }^{46}$ V. V. Ignatiev, M. V. Kormilitsyn, A. A. Lizin, A. V. Zagnitko, S. A. Konakov, A. V. Merzlyakov, S. V. Tomilin, A. A. Khokhryakov, and A. G. Osipenko. "Key Experimental Results of the PYROSMANI Project," Procedia Chemistry 21, 417-424, 2016. https://doi.org/10.1016/j.proche.2016.10.058.

${ }^{47}$ J. Zhang, C. W. Forsberg, M. F. Simpson, S. Guo, S. T. Lam, R. O. Scarlat, F. Carotti, K. Chan, P. M. Singh, W. Doniger, K. Sridharan, and J. R. Keiser. "Redox potential control in molten salt systems for corrosion mitigation," Corrosion Science 2018. 10.1016/j.corsci.2018.08.035.

${ }^{48}$ R. B. Gallaher. "Operation of the sampler-enricher in the molten salt reactor experiment," ORNL-TM-3524, 1971.

${ }^{49}$ R. H. Guymon. "MSRE Systems and components performance," ORNL-TM-3039, 292-319, 1973.

${ }^{50}$ R. B. Briggs. "Molten-salt reactor program semiannual progress report for period ending August 31, 1965," Oak Ridge National Laboratory, ORNL-3872, 1965.

${ }^{51}$ B. J. Riley, J. McFarlane, G. D. DelCul, J. D. Vienna, C. I. Contescu, C. W. Forsberg, "Molten salt reactor waste and effluent management strategies: A review," Nuclear Engineering and Design, Volume 345, 2019, Pages 94-109, 10.1016/j.nucengdes.2019.02.002.

52 R. H. Guymon. "MSRE systems and components performance," ORNL-TM-3039, 165-214, 1973.

${ }^{53}$ R. E. Thoma. "Chemical aspects of MSRE Operations," Oak Ridge National Laboratory, ORNL-4658, 127, 1972.

${ }^{54}$ R. E. Thoma. "Chemical aspects of MSRE Operations," Oak Ridge National Laboratory, ORNL-4658, 132-9, 1972

${ }^{55}$ R. E. Thoma. "Chemical aspects of MSRE Operations," Oak Ridge National Laboratory, ORNL-4658, 131-132, 1972.

${ }^{56}$ R. E. Thoma, "Chemical aspects of MSRE Operations," Oak Ridge National Laboratory, ORNL-4658, 139-142, 1972.

${ }^{57}$ P. R. Kasten. "Safety program for molten-salt breeder reactors," ORNL-TM-1858, 1967.

${ }^{58}$ R. B. Lindauer. "Processing of the MSRE Flush and Fuel Salts," Oak Ridge National Laboratory, ORNL-TM-2578, 1969.

${ }^{59}$ P. R. Kasten. "Safety program for molten-salt breeder reactors," ORNL-TM-1858, 1967.

${ }^{60}$ Y. Takahashi, M. Kamimoto, R. Sakamoto, K. Kanari, and T. Ozawa. "Thermoanalytical evaluation of eutectic mixtures of $\mathrm{LiOH}, \mathrm{NaOH}$, and $\mathrm{KOH}$ for latent heat thermal energy storage," Nippon Kagaku Kaishi, The Chemical Society of Japan 6, 10491054, 1982. doi.org/10.1246/nikkashi.1982.1049.

${ }^{61}$ M. Worsley, P. Campbell, S. Kim, and M. Merrill, M. "Molten hydroxide membrane for separation of acid gases from emissions," Lawrence Livermore National Security, LLC, WO2017200764A1, 2017.

${ }^{62}$ B. A. Fries. "Krypton-85. A versatile tracer for industrial process applications," The International Journal of Applied Radiation and Isotopes 28(10-11), 829-832, 1977.

${ }^{63} \mathrm{P}$. Monkhouse. "On-line spectroscopic and spectrometric methods for the determination of metal species in industrial processes," Progress in Energy and Combustion Science 37, 125-171, 2011.

${ }^{64}$ R. B. Lindauer and C. K. McGlothlan. "Design, Construction, and Testing of a Large Molten Salt Filter," ORNL-TM-2478, 1969.

${ }^{65}$ J. L. Willit, W. E. Miller, and J. E. Battles. "Electrorefining of uranium and plutonium - A literature review," J. Nucl. Mater 195(3), 229-249, 1992. 
${ }^{66}$ B. J. Riley, J. D. Vienna, S. M. Frank, J. O. Kroll, Z. Zhu, N. L. Canfield, K. Kruska, D. K. Schreiber, J. A. Peterson, and J. V. Crum. "Glass Binder Development for a Glass-Bonded Sodalite Ceramic Waste Form," J. Nucl. Mater. 489, 42-63, 2017.

${ }^{67}$ O. A. Lorentsen. "125 years of the Hall-Héroult process - What made it a success?" Molten Salts Chemistry and Technology, $1^{\text {st }}$ Ed., M. Gaune-Escard and G. M. Haarberg, Eds., Chapter 1.11, 103-112,2014.

${ }^{68}$ W. Cohen, W. Zhou, E. Wu, and J. Zhang. "Molten fluoride salt and liquid metal multistage extraction model," Progress in Nuclear Energy 97, 214-219, 2017.

${ }^{69}$ H. C. Savage and J. R. Hightower, Jr. "Engineering tests of the metal transfer process for extraction of rare-earth fission products from a molten-salt breeder reactor fuel salt," ORNL-5176, 1977.

${ }^{70}$ O. Conocar, N. Douyere, J. P. Glatz, J. Lacquement, R. Malmbeck, and J. Serp, J. "Promising pyrochemical actinide/lanthanide separation processes using aluminum," Nuclear Science and Engineering 153(3), 253-261, 2006.

${ }^{71}$ J. Lacquement, H. Boussier, A. Laplace, O. Conocar, and A. Grandjean, "Potentialities of fluoride-based salts for specific nuclear reprocessing: Overview of the R\&D program at CEA," 130(1), 18-21, 2009.

72 M. Straka and L. Szatmáry. "Electrochemistry of selected lanthanides in FLiBe and possibilities of their recovery on reactive electrode," Procedia Chemistry 7, 804-813, 2012.

${ }^{73}$ J. R. Hightower, Jr. and L. E. McNeese. "Measurement of the relative volatilities of fluorides of Ce, La, Pr, Sm, Eu, Ba, Sr, Y, and $\mathrm{Zr}$ in mixtures of $\mathrm{LiF}$ and $\mathrm{BeF}_{2}, " \mathrm{ORNL}-\mathrm{TM}-2058,1968$.

${ }^{74}$ J. R. Hightower, Jr., L. E. McNeese, B. A. Hannaford, and H. D. Cochran, Jr. "Low pressure distillation of a portion of the fuel carrier salt from the molten salt reactor experiment," ORNL-4577, 1971.

${ }^{75}$ C.D. Scott, W.L. Carter. "Preliminary design study of a continuous fluorination-vacuum distillation system for regenerating fuel and fertile streams in a molten salt breeder reactor", ORNL-3791, 1966.

${ }^{76}$ W.L. Carter, M.E. Watley, "Fuel and blanket processing development for molten salt breeder reactors", ORNL-TM-1852, 1967.

${ }^{77}$ H. C. Eun, J. H. Choi, I. H. Cho, T. K. Lee, T. J. Kim, J. S. Shin, H. S. Park, and D. H. Ahn. "Purification of LiCl-KCl eutectic waste salt containing rare earth chlorides delivered from the pyrochemical process of used nuclear fuel using a reactive distillation process," J. Radioanal. Nucl. Chem. 307 1419-1427, 2016.

${ }^{78}$ Y.-Z. Cho, G.-H. Park, H.-C. Yang, D.-S. Han, H.-S. Lee, and I.-T. Kim. "Minimization of eutectic salt waste from pyroprocessing by oxidative precipitation of lanthanides," J. Nucl. Sci. Technol. 46(10) 1004-1011, 2009.

${ }^{79}$ Y.-Z. Cho, B.-G. Ahn, H.-C. Eun, J.-S. Jung, and H.-S. Lee. "Melt crystallization process treatment of LiCl salt waste generated from electrolytic reduction process of spent oxide fuel," Energy Procedia 7 525-528, 2011.

${ }^{80}$ J. Lacquement, H. Boussier, A. Laplace, O. Conocar, A. Grandjean. "Potentialities of fluoride-based salts for specific nuclear reprocessing: Overview of the R\&D program at CEA,” 130(1) 18-21, 2009.

${ }^{81}$ K. Bateman, P. Stephen, "The Ceramic Waste Form Process at the Idaho National Laboratory," International Pyroprocessing Research Conference, Idaho Falls, ID, INL/CON-06-11606. Idaho National Laboratory (United States).

${ }^{82}$ Y. Liang, Y. Li, L. Xue, and Y. Zou." Extraction of rare earth elements from fluoride molten salt electrolytic slag by mineral phase reconstruction," J. Cleaner Production 177, 567-572, 2018.

${ }^{83}$ J. Plášil. "Mineralogy, crystallography and structural complexity of natural uranyl silicates," Minerals 8 (551), 1-15, 2018.

${ }^{84}$ H. Li, P. Kegler, D. Bosbach, and E. V. Alekseev. "Hydrothermal synthesis, study, and classification of microporous uranium silicates and germanates," Inorganic Chemistry 57, 4745-4756, 2018.

${ }^{85}$ M. Korenko, M. Straka, L. Szatmáry, M. Ambrová, and J. Uhlíř, J. "Electrochemical separation of uranium in the molten system LiF-NaF-KF-UF4," J. Nucl. Mater. 440, 332-337, 2013.

${ }^{86}$ K.R. Lee, B.J. Riley, H.-S. Park, J.-H. Choi, S.Y. Han, J.-M. Hur, J.A. Peterson, Z. Zhu, D.K. Schreiber, K. Kruska, M.J. Olszta, "Investigation of physical and chemical properties for upgraded $\mathrm{SAP}\left(\mathrm{SiO}_{2}-\mathrm{Al}_{2} \mathrm{O}_{3}-\mathrm{P}_{2} \mathrm{O}_{5}\right)$ waste form to immobilize radioactive waste salt," J. Nucl. Mater. 515, 382-391, 2019.

${ }^{87}$ P. Bagri and M. F. Simpson, "Occlusion and ion exchange of eutectic LiCl-KCl in H-Y zeolite," J. Nucl. Fuel Cycle Waste Technol. 13(Special), 45-53, 2015.

${ }^{88}$ A. Grandjean, Proc. of Mater. Res. Soc., Symposium FF (Solid-State Chemistry of Inorganic Materials V), 848, pp. FF-9.32, 2005.

${ }^{89}$ C. W. Forsberg, E. C. Beahm, and G. W. Parker, Proc. of Spectrum '94. Atlanta, GA, 1994.

${ }^{90}$ C. W. Forsberg, E. C. Beahm, and J.C. Rudolph, 131-137, Proc. of MRS Scientific Basis for Nuclear Waste Management XX, 465. Boston, MA, 1997.

${ }^{91}$ T. Burchell and P. Pappano. "The Characterization of Grade PCEA Recycle Graphite Pilot Scale Billets.” ORNL/TM2010/00169. Oak Ridge National Laboratory, Oak Ridge, TN, 2010.

92 W. von Lensa, D. Vulpius, H.-J. Steinmetz, N. Girke, D. Bosbach, B.T. Jülich, A.W. Banford, D. Bradbury, B. Grambow, M.J. Grave, A. N. Jones, L. Petit, and G. Pina, "Treatment and disposal of irradiated graphite and other carbonaceous waste," Int. J. Nucl. Power, 2011.

${ }^{93}$ J. H. Westsik Jr., K. J. Cantrell, R. J. Serne, and N. P. Qafoku. “Technetium Immobilization Forms Literature Survey.” PNNL23329, EMSP-RPT-023. Pacific Northwest National Laboratory, Richland, WA, 2014.

${ }^{94}$ U.S. Department of Energy Technology Readiness Assessment Guide, DOE G 413.3-4, 10-12-09, available online at: www.directives. doe.gov 